United States Department of Energy

Savannah River Site

\title{
FY01 Phytoremediation of Chlorinated Ethenes in Southern Sector Seepline Sediments of Savannah River Site
}

WSRC-TR-2001-00437

Revision 0

November 2001

Prepared by:

Westinghouse Savannah River Company LLC Savannah River Site Aiken, SC 29808

Prepared for the U. S. Department of Energy Under Contract No. DE-AC09-96SR18500 
FY 01 Phytoremediation of Chlorinated Ethenes in

WSRC-TR-2001-00437

Southern Sector Sediments of Savannah River Site

Revision 0 Savannah River Site

November 2001

\section{AUTHORS}

Robin L. Brigmon ${ }^{1}$, F. Michael Saunders ${ }^{2}$, Denis Altman ${ }^{1}$, Ed Wilde ${ }^{1}$, Christopher J. Berry $^{1}$, Marilyn Franck ${ }^{1}$, Pam McKinsey ${ }^{1}$, Shirley Burdick ${ }^{1}$, Kevin Sessions ${ }^{2}$, Andrine Stanhope $^{3}$ and Cary Tuckfield ${ }^{1}$.

Savannah River Technology Center (SRTC) ${ }^{1}$, Georgia Institute of Technology (GT) ${ }^{2}$, and Florida A\&M University ${ }^{3}$ 
This document was prepared in conjunction with work accomplished under Contract No. DE-AC09-96SR18500 with the U. S. Department of Energy.

\section{DISCLAIMER}

This report was prepared as an account of work sponsored by an agency of the United States Government. Neither the United States Government nor any agency thereof, nor any of their employees, makes any warranty, express or implied, or assumes any legal liability or responsibility for the accuracy, completeness, or usefulness of any information, apparatus, product or process disclosed, or represents that its use would not infringe privately owned rights. Reference herein to any specific commercial product, process or service by trade name, trademark, manufacturer, or otherwise does not necessarily constitute or imply its endorsement, recommendation, or favoring by the United States Government or any agency thereof. The views and opinions of authors expressed herein do not necessarily state or reflect those of the United States Government or any agency thereof.

This report has been reproduced directly from the best available copy.

Available for sale to the public, in paper, from: U.S. Department of Commerce, National Technical Information Service, 5285 Port Royal Road, Springfield, VA 22161, phone: (800) 553-6847, fax: (703) 605-6900

email: orders@ntis.fedworld.gov

online ordering: http://www.ntis.gov/help/index.asp

Available electronically at http://www.osti.gov/bridge

Available for a processing fee to U.S. Department of Energy and its contractors, in paper, from: U.S. Department of Energy, Office of Scientific and Technical Information, P.O. Box 62, Oak Ridge, TN 37831-0062,

phone: (865)576-8401,

fax: (865)576-5728

email: $\underline{\text { reports@ adonis.osti.gov }}$ 
FY 01 Phytoremediation of Chlorinated Ethenes in

WSRC-TR-2001-00437

Southern Sector Sediments of Savannah River Site

Revision 0

Savannah River Site

November 2001

This page intentionally left blank. 


\section{EXECUTIVE SUMMARY}

This treatability study is now in the second year of deployment for the Southern Sector Phytoremediation Project. Phytoremediation is the use of vegetation and associated media to treat contaminated soils, sediments, and groundwater. Phytoremediation is a rapidly developing technology that promises effective and safe cleanup of certain hazardous wastes. This ongoing work addresses the fate of volatile organic contaminants (VOCs) in an experiment that simulates a vegetated seepline supplied with trichloroethylene- (TCE-) and perchloroethylene- (PCE-) contaminated groundwater. The primary objective is to determine how the trees and sediments uptake groundwater TCE and PCE, biodegrade it, and/or transform it. The experimental focus of this project is the biological removal of VOCs from seepline groundwater and sediments.

Since October 1999 the Savannah River Site (SRS) has deployed a pilot-scale phytoremediation treatability study to support seepline remediation of chlorinated ethenes in the Southern Sector of A/M Area. The project has concentrated on groundwater upgradient of the Tims Branch seepline. The objective of the field research is to determine the efficiency of plants and soil in accomplishing in situ bioremediation of VOCs, TCE and PCE under specific site conditions. To support this objective, in FY00 three phytoreactors were deployed with soil from the seepline. Phytoreactor 1 was planted with loblolly pines (Pinus taeda), Phytoreactor 2 was planted with hybrid poplars (Trichocarpa X deltoides), and Phytoreactor 3 was left non-vegetated as a soil control to evaluate monitored natural attenuation (MNA). In FY01, two additional phytoreactors were added. Phytoreactor 4 was planted with sterile Vetiver grass, a species from Southeast Asia with proven bioremediation potential. Phytoreactor 5 was set up as a wetland system and prepared with sediments from Upper Three Runs Creek (UTRC). The wetland plants are indigenous species that naturally emerged from the sediments.

In addition to the two new phytoreactors, other major activities were initiated in FY01 to improve the treatability project based on FY00 findings. These improvements included a design change in the contaminated groundwater delivery system, reconfiguration of the phytoreactors, and addition of a weather station. The polypropylene groundwater supply tank was replaced 
with a larger stainless steel tank, new piping for the groundwater supply system was installed, flowmeters were replaced, piping was expanded to minimize flow interruptions, and insulation was reinforced. The phytoreactors were supplied with surface drains to simulate surface-runoff and soils were reworked with SRS materials and tubing was added for water depth measurements. A weather station was deployed to better measure environmental influences.

Results from FY00 demonstrated that the loblolly pine and the hybrid poplar, respectively, removed up to $90 \%$ and $100 \%$ of the VOCs. No detectable amounts of these VOCs were found in transrespiration or soil volatilization testing. This trend continued this year, with the new Vetiver and wetland systems also demonstrating up to $100 \%$ removal of groundwater contaminants. Microbial activity in the wetland sediments and seepline soils for MNA was found to be a significant factor for VOC removal. Parallel anaerobic microcosms for assessing soil biotransformation of VOCs at the Georgia Institute of Technology (GT) and SRS with seepline and wetland sediments demonstrated up to 100\% TCE removal through MNA within 6 weeks. Analysis of plant tissues in July 2001 confirmed the presence of VOCs in plant tissues from each of the phytoreactors, proving removal and uptake by the species tested. No VOC metabolites were detected in plant tissues.

The ongoing treatability study is part of a multi-year field study of the Southern Sector seeplinesoil system maintained under saturated conditions. The primary focus is on determining the roles of plants, soil microbial communities, and geochemical and surface-volatilization processes in determining the fate of TCE- and PCE-contaminated groundwater that flows through the seepline. Previous observations indicated that biogeochemical processes of plants are seasonal, as are seepline flows. Therefore, FY01 data represent the seasonal baseline for soil and plant systems for comparison with seepline phyto- and bioactivity in subsequent FY02 growth seasons.

The removal of chlorinated ethenes from the groundwater and seepline sediments by phytoremediation and MNA in this treatability study is promising. Although this treatability project is ongoing, results to date show removal of VOCs from groundwater with the seepline 
soils and associated vegetation. There is evidence of VOC removal by plants in phytoreactors. This removal was higher in poplar and wetland systems that contained the most biomass. There was not a significant difference comparing VOC removal by all phytoreactors, indicating that thus far MNA is the primary removal mechanism. These findings will be applied in FY02 to the Tims Branch flood plain and seepline. 
FY 01 Phytoremediation of Chlorinated Ethenes in

WSRC-TR-2001-00437

Southern Sector Sediments of Savannah River Site

Revision 0

Savannah River Site

Page ES-4 of ES-4

November 2001

This page intentionally left blank. 
FY 01 Phytoremediation of Chlorinated Ethenes in

WSRC-TR-2001-00437

Southern Sector Sediments of Savannah River Site

Revision 0

Savannah River Site

Page i of iv

November 2001

SECTION:

TABLE OF CONTENTS

EXECUTIVE SUMMARY ES-1

LIST OF FIGURES i

LIST OF TABLES iii

LIST OF APPENDICES iii

LIST OF ACRONYMS iv

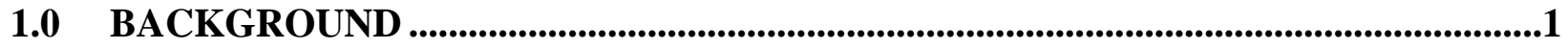

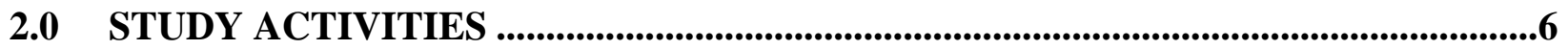

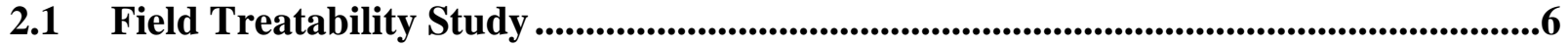

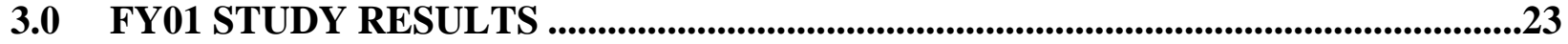

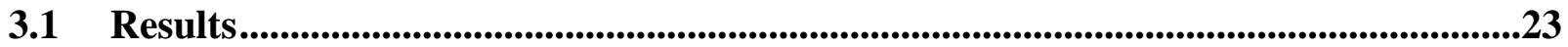

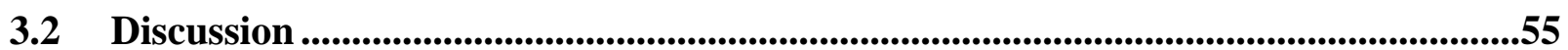

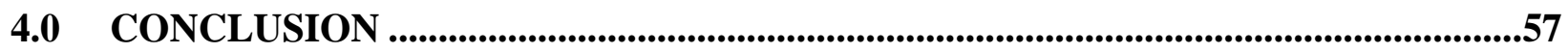

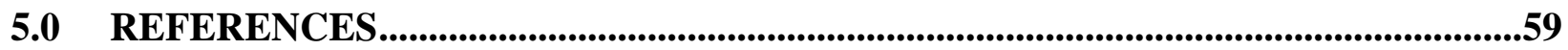

\section{LIST OF FIGURES}

Figure 1. Phytoremediation System in Southern Sector of A/M AReA DEMONSTRATING GROUNDWATER SUPPLY SYSTEM, FIVE PHYTOREACTORS AND THE EFFLUENT COLLECTION SYSTEM .........................................................7

Figure 2A. Setup of Phytoreactor 1 With Pine Trees At MSB 88C ...............................9

Figure 2B. SETUP OF PHYTOREACTOR 2 With Poplar TREeS AT MSB 88C .....................10

Figure 2C. Setup of Phytoreactor 3, Non-Vegetated Control AT MSB 88C .........11

FIGURE 2D. SETUP OF PHYTOREACTOR 4 WITH VETIVER GRASS AT MSB 88C.....................15

Figure 2E. SETUP OF PHYTOREACTOR 5 WITH WETLAND SYSTEM AT MSB 88C .................16

FIGURE 3. WEATHER DATA FROM VICINITY OF MSB 88C FOR SUMMER OF 2001..............24

FigURE 4A. GROUNDWATER INFLUENT FLOW DATA FOR PHYTOREACTOR 1 ......................25

FIGURE 4B. GROUNDWATER INFLUENT FLOW DATA FOR PHYTOREACTOR 2 ......................26

FIGURE 4C. GROUNDWATER INFLUENT FLOW DATA FOR PHYTOREACTOR 3 ......................27

FIGURE 4D. GROUNDWATER INFLUENT FLOW DATA FOR PHYTOREACTOR 4 ......................28

Figure 4E. GRoundWATER INFLUENT Flow DATA For PHYTOREACTOR 5 .........................29

Figure 5. TCE AND PCE GROUNDWATER CONCENTRATIONS IN MCB 88C FROM SEPTEMBER 1998 UNTIL JANUARY 2001 (SOURCE: GIMS)..................................31 
FY 01 Phytoremediation of Chlorinated Ethenes in

WSRC-TR-2001-00437

Southern Sector Sediments of Savannah River Site

Revision 0

Savannah River Site

Page ii of iv

November 2001

Figure 6A. APril 2001 GroundWATER TCE DATA For PhYTOREACTORS 1 THROUgh $5 \ldots . . . .32$

Figure 6B. APRIL 2001 GROUNDWATER PCE DATA FOR PHYTOREACTORS 1 THROUGH

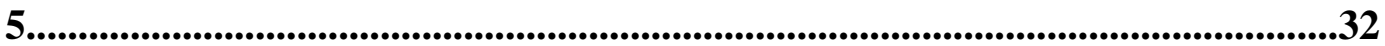

Figure 7A. MAY 2001 GroundWATER TCE DAta For Phytoreactors 1 Through 5 ...33

Figure 7B. MAY 2001 GroundWATER PCE DATA FOR PHYTOREACTORS 1 THROUgh 5 ...33

Figure 8A. JunE 2001 GroundWATER TCE DATA FOR PHYTOREACTORS 1 THROUgh 5...34

Figure 8B. JunE 2001 GroundWATER PCE DATA FOR PHYTOREACTORS 1 THROUgh 5 ...34

Figure 9A. JUly 2001 GroundWATER TCE DATA FOR PHYTOREACTORS 1 THROUgh $5 . . .35$

Figure 9B. July 2001 GroundWATER PCE DATA For PHYTOREACTORS 1 THROUgh 5 ...35

FIGURE 10. GROUNDWATER INFLUENT AND EFFLUENT TCE CONCENTRATION $(\mu \mathrm{G} / \mathrm{L})$

DIFFERENCES FOR EACH OF THE FIVE PHYTOREACTORS WITH

CORRESPONDING DUNNETT'S TEST COMPARISON CIRCLES.................................36

Figure 11. GROUNDWATER INFLUENT AND EFFLUENT PCE CONCENTRATION $(\mu \mathrm{G} / \mathrm{L})$

DIFFERENCES FOR EACH OF THE FIVE PHYTOREACTORS WITH

CORRESPONDING DUNNETT'S TEST COMPARISON CIRCLES.

Figure 12. Phytoreactor Plots of Both TCE And PCE Concentration $(\mu \mathrm{G} / \mathrm{Kg})$

MEASUREMENTS IN SOIL SAMPLES FROM PHYTOREACTORS 1 THROUGH 5 AND TWO SAMPLING DEPTHS (SHAL=SHALLOW \& DEEP)

Figure 13. Phytoreactor Plots of Both TCE And PCE Concentration $(\mu \mathrm{g} / \mathrm{Kg})$

MEASUREMENTS TAKEN FROM FOUR DIFFERENT TYPES OR PLANT

Communities ACross all Categories of Plant Tissues.

MEASUREMENTS ARE REPORTED AS THE COMMON LOGARITHMS

Figure 14. Plots of Both TCE ANd PCE Concentration Measurements $(\mu \mathrm{G} / \mathrm{Kg})$

TAKen From SEVEn Different CATEgories of Plant Tissues ACROSS

all Plant Types. Measurements Are Reported as the Common

LOGARITHMS

FigURE 15. MICROBIAL DEGRADATION OF TCE IN SOUTHERN SECTOR WETLAND

SEDIMENTS

Figure 16. MICROBIAL DEGRADATION OF TCE IN SOUTHERN SECTOR RHIZOSPHERE

SEDIMENTS AMENDED WITH OSMOCOTE ${ }^{\circledR}$.

Figure 17. MiCRobial DEGRADATION OF TCE IN SOUTHERN SECTOR RHIZOSPHERE

SEDIMENTS AMENDED WITH SOYBEAN OIL ..........................................................46

Figure 18. MICROBIAL DEGRADATION OF TCE IN SOUTHERN SECTOR RHIZOSPHERE

SEDIMENTS AMENDED WITH OSMOCOTE ${ }^{\circledR}$ + SOYBEAN OIL ...............................46

Figure 19. MICROBIAL DEGRADATION OF TCE IN SOUTHERN SECTOR RHIZOSPHERE SEDIMENTS WITH NO AMENDMENTS ..................................................................47

Figure 20. MiCRobial DEGRADATION OF TCE IN SOUTHERN SECTOR RHIZOSPHERE

SEDIMENTS IN KILLED CONTROL

FIGURE 21. TOTAL COLONY-FORMING UNITS (CFU) (BACTERIA/GRAM DRY WEIGHT) FOR SHALLOW AND DEEP PHYTOREACTOR SOILS.

FigurE 22. TOTAL MICROBIAL DENSITIES (BACTERIA/ML) FOR INFLUENT AND

EFFLUENT PHYTOREACTOR GROUNDWATER

Figure 23. Total Colony-Forming Units (CFUs) in PHYTOREACtors Influent AND EFFLUENT GROUNDWATER WATER FOR 2001 
FY 01 Phytoremediation of Chlorinated Ethenes in

WSRC-TR-2001-00437

Southern Sector Sediments of Savannah River Site

Revision 0

Savannah River Site

Page iii of iv

November 2001

FIGURE 24. TOTAL MICROBIAL DENSITIES (BACTERIA/GRAM DRY WEIGHT) FOR SHALLOW AND DEEP PHYTOREACTOR SOILS ..............................................56

\section{LIST OF TABLES}

Table 1. Plant Tissue Chlorinated Ethene Concentrations Summary ................41

Table 2. Phytoreactor Soll-Gas Carbon Dioxide Production Rates, MOISTURE, PCE AND TCE CONCENTRATIONS

TABLE 3A. ANION RESUlTS FOR SOUTHERN SECTOR SOIL AND INFLUENT AND EFFLUENT

GROUNDWATER ...................................................................................................51

TABLE 3B. CATION RESUlTS FOR SOUTHERN SECTOR SOIL AND INFLUENT AND

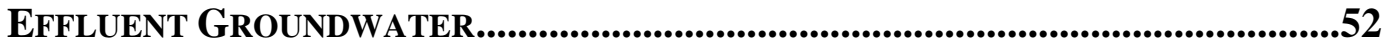

\section{LIST OF APPENDICES}

APPENDIX 1. SOIL AND GROUNDWATER CHLORINATED ETHENE DATA ... A1-1

APPENDIX 2. PLANT CHEMICAL DATA.............................................................. A2-1 


\section{LIST OF ACRONYMS}

AODC

ANOVA

ASCII

${ }^{\circ} \mathrm{C}$

c-DCE

DCA

EBS

FID

g

$\mathrm{gal} / \mathrm{d}$

GC

GIMS

GT

ID

L

m

$\mathrm{mg} / \mathrm{L}$

$\mathrm{mL}$

$\mu \mathrm{L}$

$\mathrm{mL} / \mathrm{min}$

$\mu \mathrm{m}$

$\mathrm{mm}$

$\mathrm{mM}$

$\mathrm{M} / \mathrm{min}$

MCB

MNA

MS

PCE

ppm

PVC

PTYG

rpm

SRS

SRTC

TCA

TCE

TSCF

UTRC

VC

VOC

WSRC
Acridine Orange Direct Count

Analysis of Variance

American Standard Code for Information Interchange

centigrade

cis-1,2-dichloroethylene

dichloroacetic acid

Environmental Biotechnology Section

flame ionization detector

gram

gallon per day

gas chromatography

Geochemical Information Management System

Georgia Institute of Technology

inner diameter

liter

meter

milligrams per liter

milliliter

microliter

milliliter per minute

micrometer

millimeter

millimolar

meter per minute

Miscellaneous Chemical Basin

monitored natural attenuation

mass spectrometry

perchloroethylene (or tetrachloroethylene)

parts per million

polyvinyl chloride

Peptone-Trypticase-Yeast Extract-Glucose

revolutions per minute

Savannah River Site

Savannah River Technology Center

trichloroacetic acid

trichloroethylene

Transpiration stream concentration factor

Upper Three Runs Creek

vinyl chloride

volatile organic compound

Westinghouse Savannah River Company 


\subsection{BACKGROUND}

It has been estimated that over 13 million pounds of chlorinated degreasing solvents, including trichloroethylene (TCE) and perchloroethylene (PCE), were used at Savannah River Site (SRS) during reactor operations (WSRC 1996). Although much of the waste volume was reduced by evaporation, over 3 million pounds of the solvents, including 317,000 pounds of TCE, were discharged to the M-Area Settling Basin and the A-014 outfall. The M-Area Settling Basin and A-014 outfall were unlined and much of these solvents seeped into the subsurface, contaminating the groundwater. The associated groundwater zones in $\mathrm{A} / \mathrm{M}$ Area (i.e., $\mathrm{M}$ Area and Lost Lake aquifers) discharge to seeplines adjacent to Tims Branch and Upper Three Runs Creek (WSRC 1999). As part of the ongoing compliance and research activities at SRS, evaluations of the nature and extent of groundwater contamination in the $\mathrm{A} / \mathrm{M}$ Area are ongoing in the Southern Sector. Based on the local hydrogeology and topography, it was predicted that VOCcontaminated groundwater would emerge as surface water along a seepline region in the Southern Sector of the A/M Area.

Natural remediation options such as phytoremediation and monitored natural attenuation (MNA) are the preferred alternatives for fringe areas of contaminant plumes. In A/M Area, SRS is investigating the potential for implementing these techniques in combination with aggressive source zone treatments in higher plume concentration areas. Identifying the probable location of future plume discharges, magnitudes, and structure in the distal fringe is critical to the implementation and long-term performance of MNA. The treatability study for this projected impact zone is an important component to providing baseline data necessary for remedial assessment. In this investigation, phytoremediation and MNA for the seepline portion of the area impacted by large chlorinated ethene solvent plume are being evaluated. The potential success of phytoremediation is based on a combination of several parameters, including the impact of sediment microbial activity and vegetation interactions and physical factors such as seepline groundwater flow. In this study these concepts were integrated and used to 
design the treatability study. These results provided detailed information on the fate of contamination in the groundwater and successfully demonstrated uptake by tested vegetation and microbial transformation of volatile organic compounds (VOCs) in seepline sediments.

A recent study utilizing diffusion-based sampling techniques and coring activities, accompanied by depth-discrete sediment analysis, indicated the presence of TCE and PCE at the seepline, which demonstrated that the plume is outcropping (WSRC 2000b). Samples from monitoring wells installed in this region further substantiated this finding. The concentrations associated with this outcrop region are $25 \mu \mathrm{g} / \mathrm{L}$ for TCE and $10 \mu \mathrm{g} / \mathrm{L}$ for PCE, with the width of region affected on the order of 2,000 feet. To date no VOCs have been detected in the stream.

To effectively monitor these discharges and confirm MNA, SRS will continue long-term monitoring of seepline groundwater and sediment VOC concentrations associated with the identified seepline outcrop region. In the FY01 study, the biological features of the seepline were considered in conjunction with fundamentals of groundwater flow and contaminant transport to directly characterize phytoremediation and MNA. By integrating the important characteristics of groundwater flow and bioremediation, the fate of contaminants entering the seepline can be predicted. The study emphasizes the importance of understanding the role of combining groundwater flow and biological interactions when planning natural attenuation strategies. These baseline measurements and characterization approaches will be of significant benefit in assessing the long-term performance of the planned MNA and phytoremediation activities.

The seepline is presently heavily covered with a variety of vegetation. This area lends itself to MNA and phytoremediation with plant species known to uptake VOCs. The area has a wide variety of trees, including bald cypress (Taxodium distichum), tupelo (Nyssa aquatica), loblolly pine (Pinus taeda), oak (Quercus spp.) and sweet gum (Liquidambar stryaciflua), which have been shown to take up chlorinated ethenes (Vroblesky, et al. 
1999). Walton and Anderson (1990) previously observed accelerated microbial degradation of TCE in SRS rhizospheric soils and related whole plant systems (Anderson and Walton 1995).

The extent to which VOC remediation occurs in rhizosphere soils in this area is uncertain. However, a better understanding of such variability is necessary since MNA responds to seasonal changes including plant growth, rainfall, and temperature. All of these can significantly influence potential VOC bioremediation. A microcosm study designed to estimate the bioremediation potential of seepline soils demonstrated that sorption was the dominant mechanism, removing as much as 90\% TCE (Brigmon, et al. 1998). A limited amount of TCE aerobic biodegradation and anaerobic reductive dechlorination was observed, including cis-1, 2-dichloroethylene (c-DCE). Soils from vegetated areas mineralized TCE several times more quickly than soils from adjacent non-vegetated areas (Walton and Anderson 1990).

It has been suggested that a possible mechanism for the enhanced microbial mineralization of TCE in the $L$. cuneata rhizospheric soil is excretion of phenolic compounds in root exudates. Since phenol is a known inducer of toluene monooxygenase, an enzyme responsible for degradation of TCE, the natural plant exudates could play a role in biodegradation of TCE in the rhizosphere (Anderson, et al. 1993). Select plants, including hybrid poplars, are capable of TCE metabolism and transformation (Newman et al. 1997 and Schnabel et al. 1997). The two tree species selected for this study based on their phytoremediation potential were the loblolly pine, $L$. cuneata, and a hybrid poplar, Trichocarpa $\mathrm{X}$ deltoides. In this project, both soil microbial and tree activity as pertaining to VOC attenuation are being monitored.

One of the primary functions of root exudates is to mobilize inorganic nutrients in the rhizosphere (Fletcher and Hedge 1995). Exudates also contain natural chelating agents (citric, acetic, and other organic acids) that make the ions of both nutrients and contaminants more mobile in the soil. Exudates may also contain enzymes including 
dehalogenases (Hedge and Fletcher 1996). These enzymes have important natural functions and may also degrade organic contaminants (Fliermans et al. 1988). Some rhizospheric microorganisms secrete hormones that increase root growth, and thereby the secretion of root exudates that contain metabolites, including proteins and carbohydrates, used by the bacteria (Shann 1995). Exudation of organics by plant roots and turnover of organic root biomass have also been found to increase the TCE sorption capacity of soil (Schnabel et al. 1997). There are knowledge gaps as to which mechanism provides the higher degree of VOC removal in phytoremediation systems, the plants or the associated rhizospheric bacteria (Orchard et al. 2000a). The microbial ecology of soils associated with bioremediation in mycorrhizal roots such as pine has not been well characterized even though this environment forms a large habitat and provides extensive surface area for bacterial colonization. It was previously observed that the rhizosphere soils in the SRS Miscellaneous Chemical Basin (MCB) contained higher quantities of potential TCEdegrading bacteria than did SRS soils not exposed to TCE (Brigmon et al. 1999). Nichols et al. (1997) has previously demonstrated higher microbial populations present in organic-contaminated rhizosphere soils than in non-contaminated soils. The microbial data from this year emphasize the heterogeneous nature of rhizosphere interactions and provides a foundation for more focused VOC biotransformation studies in FY02. Increased microbial activity is evident in outcropping zones where available organic carbon in soils and groundwater can stimulate microbial action and lower redox potential (WSRC 2000b). However, this plume outcrop area may not support sufficient microbial activity to completely mineralize TCE degradation products such c-DCE or vinyl chloride (VC) and result in the discharge of c-DCE- and VC-contaminated groundwater.

Most compounds in soil must be in solution to be affected (absorbed, modified, degraded, sequestered, etc.) by either plants or microorganisms (Shimp et al. 1993). Thus, water movement and nutrient availability in the rhizosphere is a critical factor as plants take up many times more water than is needed for growth. This additional water is transpired through the leaves as the final step in nutrient transport. Transpiration stream concentration factors (TSCFs) are important for estimating the plant uptake of TCE- 
contaminated groundwater (Orchard et al. 2000b). The groundwater and associated compounds dissolved in it moves through the rhizosphere, where it is subjected to processing by microorganisms before it enters the root system. In some instances, the magnitude of microbial transformation of TCE can be significantly larger than plant influence (Anderson and Walton 1995) although this depends on the site and plants used (Nichols et al. 1997 and Schnabel et al. 1997).

Recent microbial characterization events have confirmed the presence of potential TCEdegrading bacteria including sulfate reducers in the seepline sediments (WSRC 2000b). The occurrence of these bacteria in these sediments indicates favorable in situ microbial potential. Questions remain as to whether the microbial activity is carbon-source or nutrient-limited. The focus of the microcosm study is to determine if MNA alone is adequate or if an appropriate carbon-source/nutrient addition is necessary to stimulate in situ microbial degradation of TCE in the seepline sediments.

A better understanding of the mechanisms that enhance biodegradation in the root zone and the interaction between plants, microorganisms, and contaminants can be useful in environmental restoration (Nelson et al. 1988). This information could lead to management practices for phytoremediation applications including plant selection, soil amendments, and irrigation systems. Future work based on these results can be used to determine phytoremediation deployments and strategies in response to TCE/PCEcontaminated groundwater movement through the Southern Sector seepline. The techniques described here in conjunction with other applications should provide tools for screening plant species and soils for phytoremediation and MNA activity. Applications of phytoremediation should provide significant advantages over conventional remediation techniques for chlorinated ethene-contaminated groundwater as in the Argonne National Laboratory deployment (Quinn et al. 2001). The metabolic actions of the plants and soils in combination with physical reductions of VOCs by volatilization and dilution will enable active remediation at the rhizosphere of the seepline. 


\section{$2.0 \quad$ STUDY ACTIVITIES}

\subsection{Field Treatability Study}

The treatability study continued in 2001 in the Well MSB 88C location. The soil (very sandy with red clay) in the area of MSB 88C is not representative of the seepline. Therefore, soil was brought from the seepline to the study site for use in the phytoreactors. An additional load of soil (2 cubic yards) was brought to the site for FY01 work. Soils above ( 0 to 1.64 feet below surface) and below the rhizosphere (1.64 to 3.28 feet below surface) were collected in the vicinity of Well MSB 50 (located just above the seepline area) for the study. An additional 3 cubic yards of wetland-type soils were brought to the site from Upper Three Runs Creek (UTRC) for the wetland phytoreactor. Two additional double-insulated boxes (72 x 48 x 30 inches) (Bonar Inc., Atlanta, GA) were purchased and brought to the site to set up as phytoreactors. Figure 1 shows a diagram of the FY01 project field deployment configuration.

The phytoreactors were developed with an upflow pattern of groundwater flow to simulate the seepline. Groundwater from MSB 88C was pumped into the tank that supplies the phytoreactors though a gravity-fed system. A 3-inch layer of gravel was placed in the bottom of the phytoreactors to support a two-line influent-distribution system in the bottom of each phytoreactor. The gravel layer was then covered with 20 inches of seepline soil.

Two separate effluent collection systems were included in each phytoreactor. The effluent collection lines are located 10 inches and 18 inches (i.e., immediately below the soil surface) above the influent lines and parallel to them. This flow pattern simulates groundwater upflow through the seepline soils and the collection and removal below the root zone of the plants. The effluent collection system at the 10-inch depth is used in all phytoreactors and provides a 10-inch saturated flow zone and a 10-inch vadose zone for the phytoreactors. 
FY 01 Phytoremediation of Chlorinated Ethenes in

WSRC-TR-2001-00437

Southern Sector Sediments of Savannah River Site

Revision 0

Savannah River Site

Page 7 of 62

November 2001

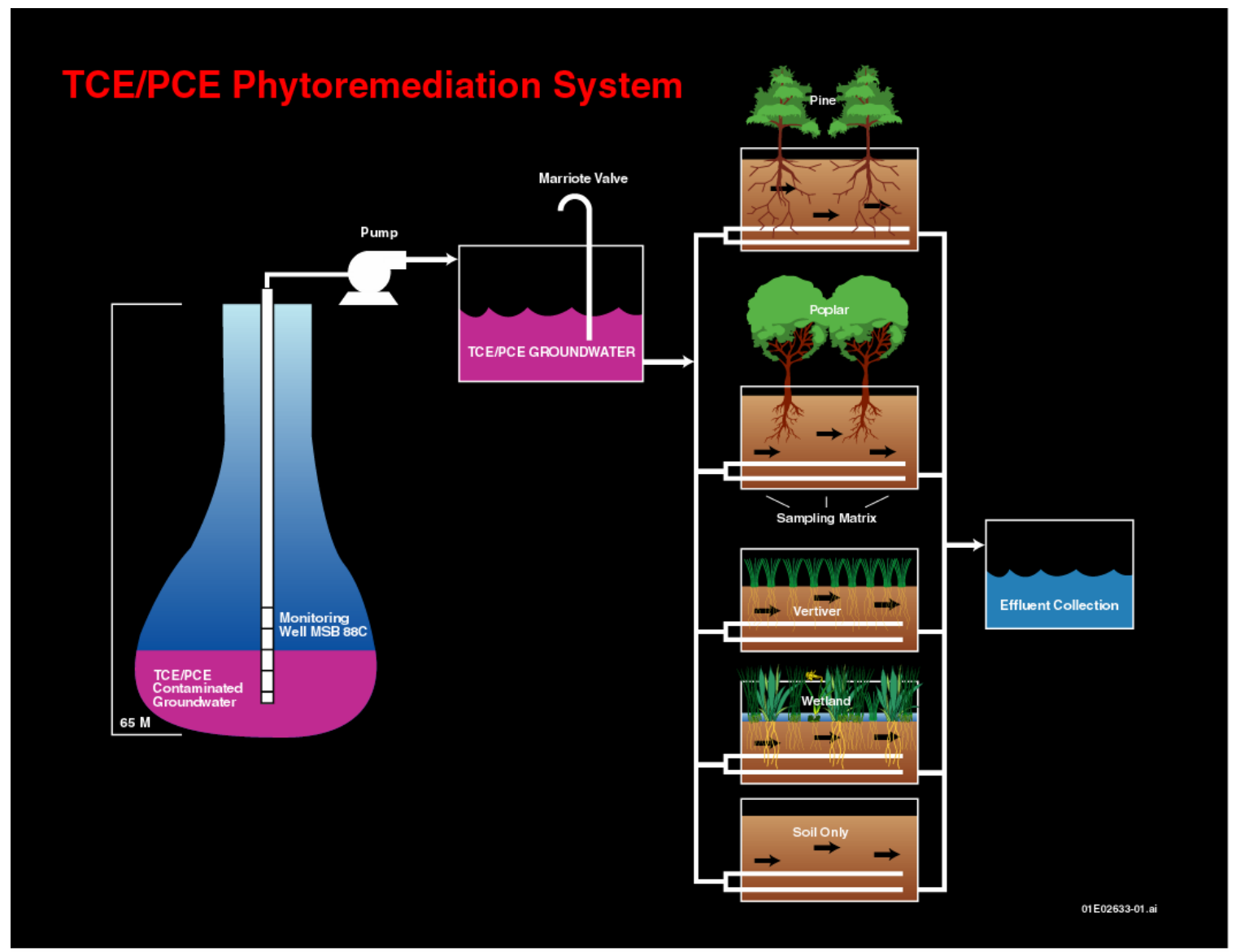

Figure 1. Phytoremediation System in Southern Sector of A/M Area demonstrating groundwater supply system, five phytoreactors and the effluent collection system 
Three phytoreactors were set up in FY00 for the project. Loblolly pine (L. cuneata) was planted in Phytoreactor 1 (Figure 2a), the hybrid poplar (Trichocarpa $X$ deltoides) in Phytoreactor 2 (Figure 2b), and Phytoreactor 3 (Figure 2c) contained only seepline soil as a non-vegetated control (Figures 2a through c). Phytoreactor 1 originally had nine pine trees and Phytoreactor 2 had seven poplars planted at the beginning of the 2000 season. At the end of 2000, Phytoreactor 1 had been thinned to six pines and Phytoreactor 2 had been thinned to three poplars based on growth. A 1,000-gallon steel tank is used for effluent collection downhill from the site and emptied every other week.

\subsubsection{System Modifications}

A number of changes were made to the test site in FY01 based on observations and conclusions from the FY00 report. These modifications are described below.

\section{$\underline{\text { 2.1.1.1 } \quad \text { Surface Drains }}$}

Surface drains were installed on the south side of Phytoreactors 1 through 4 using vented horizontal 11/2-inch polyvinyl chloride (PVC) pipe in a French drain design. The top of the piping was leveled at approximately five inches below the soil surface. Pea-gravel was placed around the circumference of the drainpipe to extend approximately 3 inches from the edge of the pipe, leaving 2 inches of soil cover atop the drainpipe with overflow water from rain being collected at the corner of the box. Overflow is then discharged to the lined area containing the phytoreactors (i.e., direct discharge into a lined gravel layer). This surface drain work was coupled with re-working the phytoreactor surface soils.

\subsubsection{Depth of Groundwater Table/Hydraulic Conductivity}

Sight-tubes were added utilizing existing sampling ports to allow for visual monitoring of the phytoreactor water tables. Manometers were also installed utilizing two existing ports on the sides of each phytoreactor. Parallel installation was selected to allow headloss measurement within the finite soil depth. 
FY 01 Phytoremediation of Chlorinated Ethenes in

WSRC-TR-2001-00437

Southern Sector Sediments of Savannah River Site

Revision 0

Savannah River Site

Page 9 of 62

November 2001

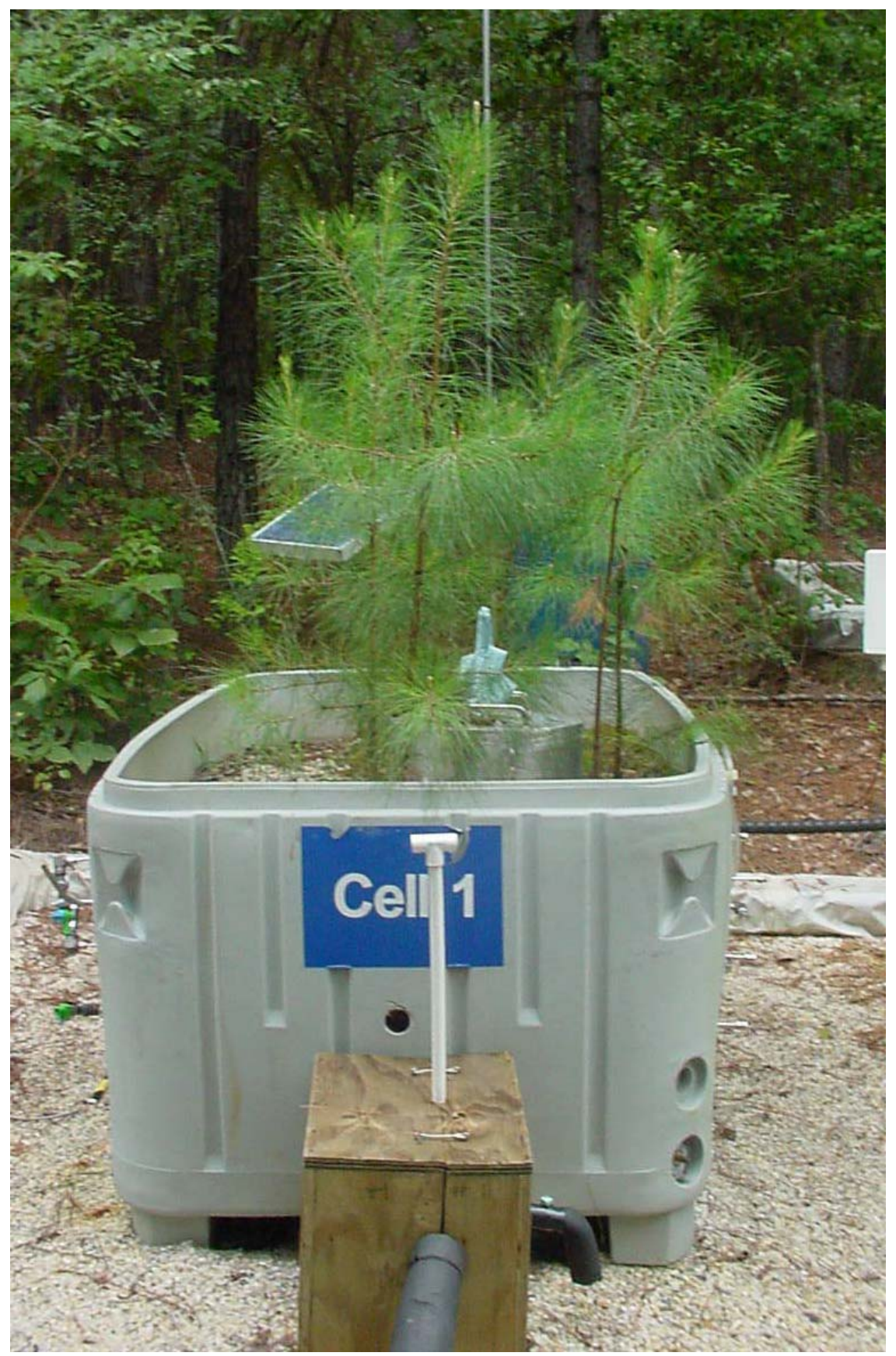

Figure 2a. Setup of Phytoreactor 1 with Pine Trees at MSB 88C 
FY 01 Phytoremediation of Chlorinated Ethenes in

WSRC-TR-2001-00437

Southern Sector Sediments of Savannah River Site

Revision 0

Savannah River Site

Page 10 of 62

November 2001

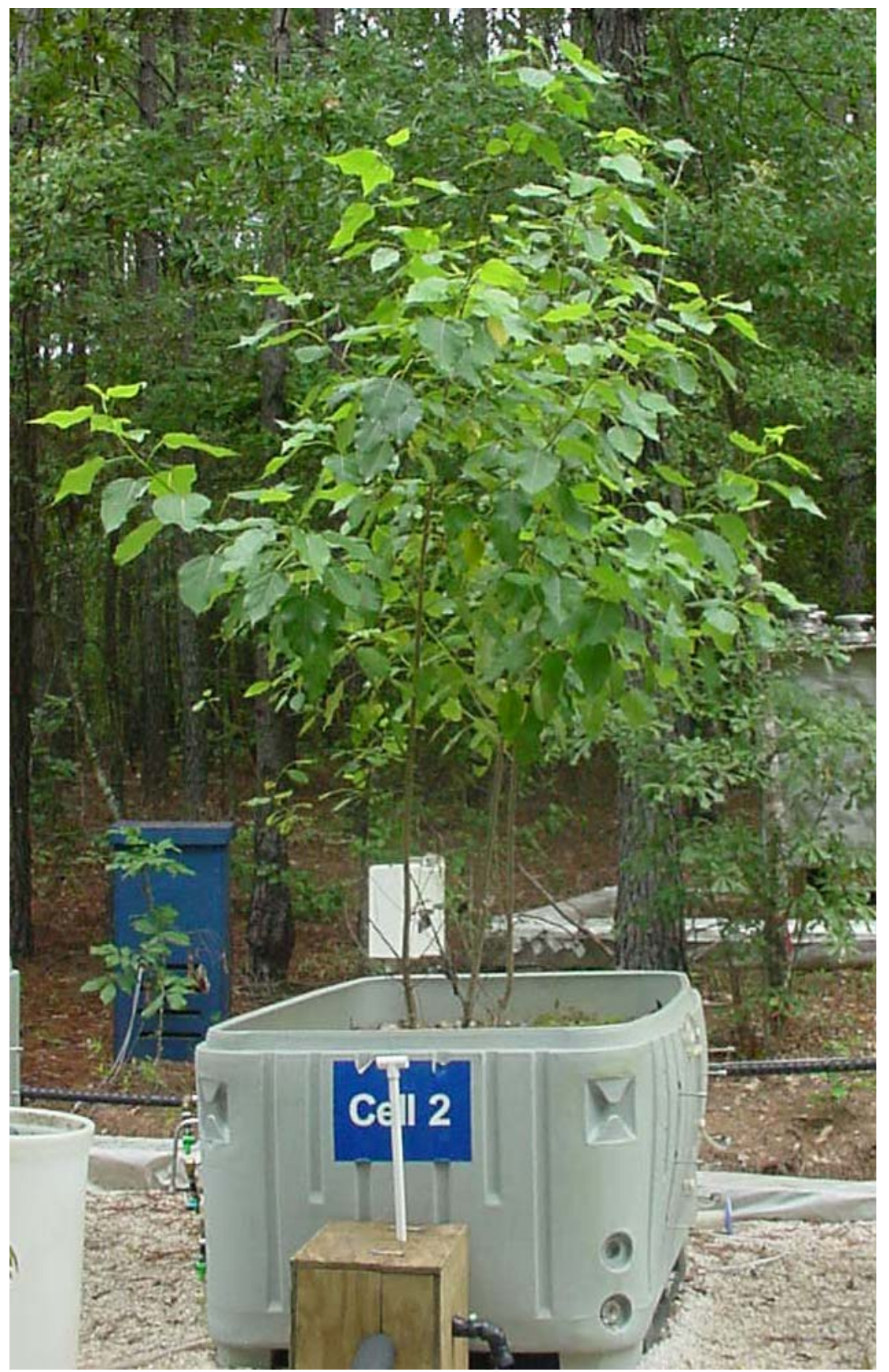

Figure 2b. Setup of Phytoreactor 2 with Poplar Trees at MSB 88C 
FY 01 Phytoremediation of Chlorinated Ethenes in

WSRC-TR-2001-00437

Southern Sector Sediments of Savannah River Site

Revision 0

Savannah River Site

Page 11 of 62

November 2001

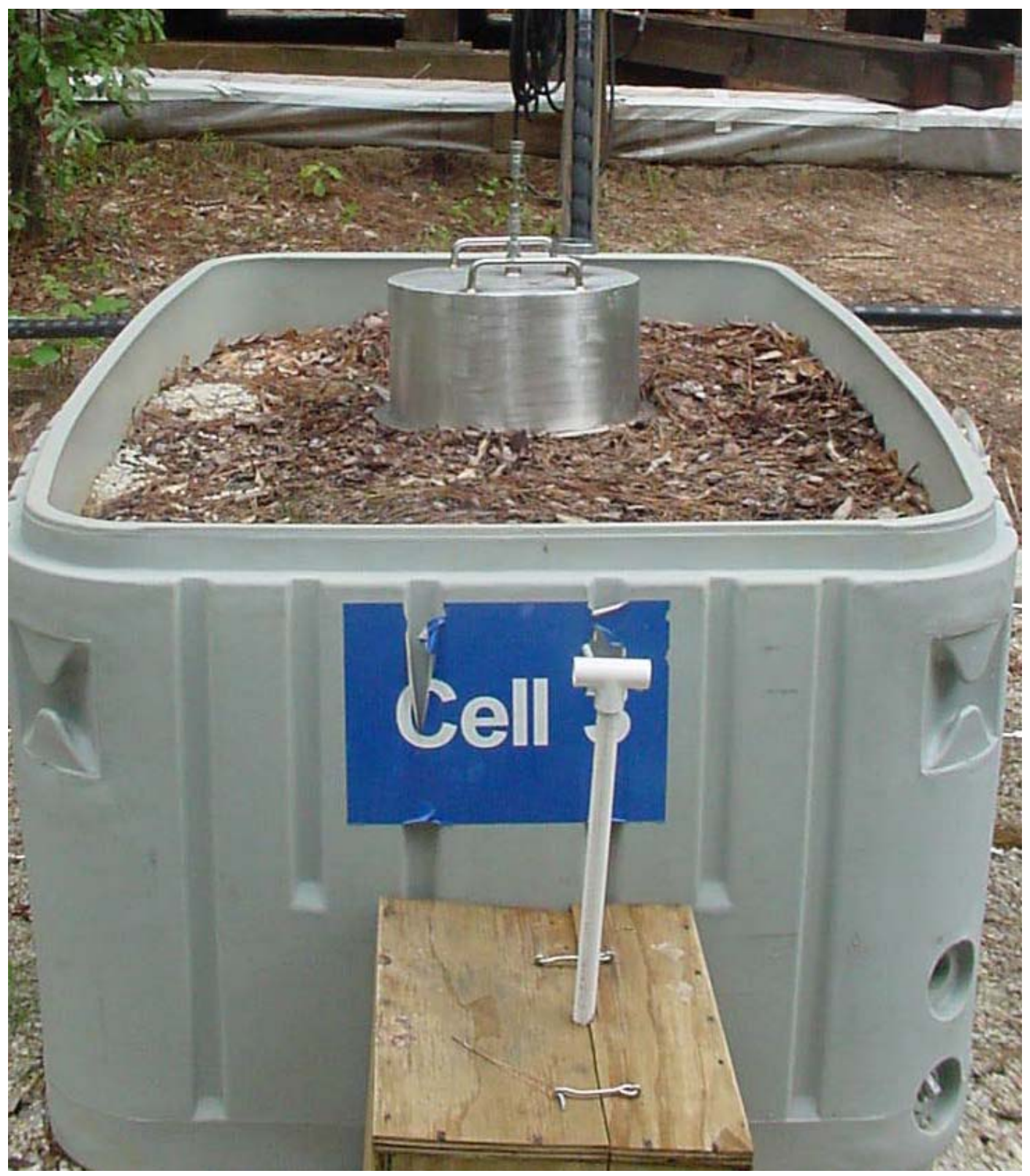

Figure 2c. Setup of Phytoreactor 3, Non-Vegetated Control at MSB 88C 
FY 01 Phytoremediation of Chlorinated Ethenes in

WSRC-TR-2001-00437

Southern Sector Sediments of Savannah River Site

Revision 0

Savannah River Site

Page 12 of 62

November 2001

$\underline{\text { 2.1.1.3 }}$ 


\section{$\underline{\text { Influent System }}$}

In an effort to minimize volatilization and fluctuations in influent flow rates, a Mariotte constant head system was developed (Nietch et al. 1999). A Mariotte tank is a sealed tank with a submerged vent. The rate of water flow from the Mariotte tank to the phytoreactors is driven by changes in hydrostatic pressure. As water flows out of the tank, a vacuum is established in the headspace above the water. The vacuum depends on the submerged depth of the vent line. As the water level falls, the vacuum level decreases proportionally, helping to maintain a relatively constant head at the tank outlet.

The implementation of the Marriotte system necessitated the replacement of the polypropylene tank with one capable of sustaining a vacuum. In November 2000, the existing tank was replaced with a 1,500-gallon stainless steel tank. All flanged connections were reinstalled with new gaskets. The square opening on the top of the tank was fitted with a clear plexiglas plate and sealed. A 3/4-inch flanged connection was selected as the entry point for the influent flow from MSB 88C. A vent valve was installed on the tank top to be opened only while filling the tank. A $1 / 2$-inch stainless steel tube was installed at the tank top to serve as the submerged vent line. The bottom of the tube was designed as the control point for discharge and set at the minimum water depth for the tank. Water exits the stainless steel tank through a 11/2-inch opening, which, prior to entering an in-line particulate $(70 \mu \mathrm{m})$ filter, is reduced to 1-inch stainless steel piping. The line is further reduced to $1 / 2$-inch stainless steel tubing prior to branching into individual feed lines. New flow meters were also installed for each cell.

\section{$\underline{\text { 2.1.1.4 } \quad \text { Freeze Protection }}$}

All lines with water flow were wrapped with $1 / 2$-inch foam insulation. In addition, insulated wooden boxes were built over the effluent lines and associated sampling ports. The boxes were designed to provide both additional freeze protection and easy access for sampling. 


\section{$\underline{\text { 2.1.1.5 }}$ Surface Soil}

The top three inches of soil in each phytoreactor was carefully leveled and graded towards the surface drains. Additional soil was added where necessary due to settling. The surface soil was supplemented with "mulch" (pine straw and wood chips) to enhance drainage and runoff, as well as provide a means for incorporation of amendments to surface soils. The "mulch" supplement was materials (pine straw etc.) collected from the adjacent wooded area. The fertilizer amendment Osmocote ${ }^{\circledR}$ (Scotts-Sierra Horticultural Products Co., Marysville, $\mathrm{OH}$ ), a slow release fertilizer, was applied in April and June at the manufacturer's recommended rate of 6 tablespoons per phytoreactor.

\subsubsection{Effluent Piping}

The effluent PVC piping from the phytoreactors to the collection tank was increased in diameter from $1 / 2$ to $1 \frac{1}{2}$ inch. All effluent piping was freeze-protected with foam insulation.

\section{$\underline{\text { 2.1.1.7 }} \quad \underline{\text { Additional Phytoreactors }}$}

Phytoreactor 4 (Figure 2d) was designed similar to the first three and planted with six Vetiver grass clusters (Vetiveria zizanioides), which was shown in FY00 field tests to grow in Southern Sector soils to depths of 3.28 feet in 3 months. Vetiver is a grass that has been used worldwide for erosion control. This grass has an extensive root system that can penetrate soil to a depth up to 9.84 feet. It has been tested extensively in Environmental Biotechnology Section (EBS) greenhouse studies and is now being fieldtested for stabilization and remediation of SRS soils.

Phytoreactor 5 (Figure 2e) was set up with wetland sediments (1.5 cubic yards) from UTRC. This phytoreactor is kept fully saturated. The water level is constantly maintained 
FY 01 Phytoremediation of Chlorinated Ethenes in

WSRC-TR-2001-00437

Southern Sector Sediments of Savannah River Site

Revision 0

Savannah River Site

Page 15 of 62

November 2001

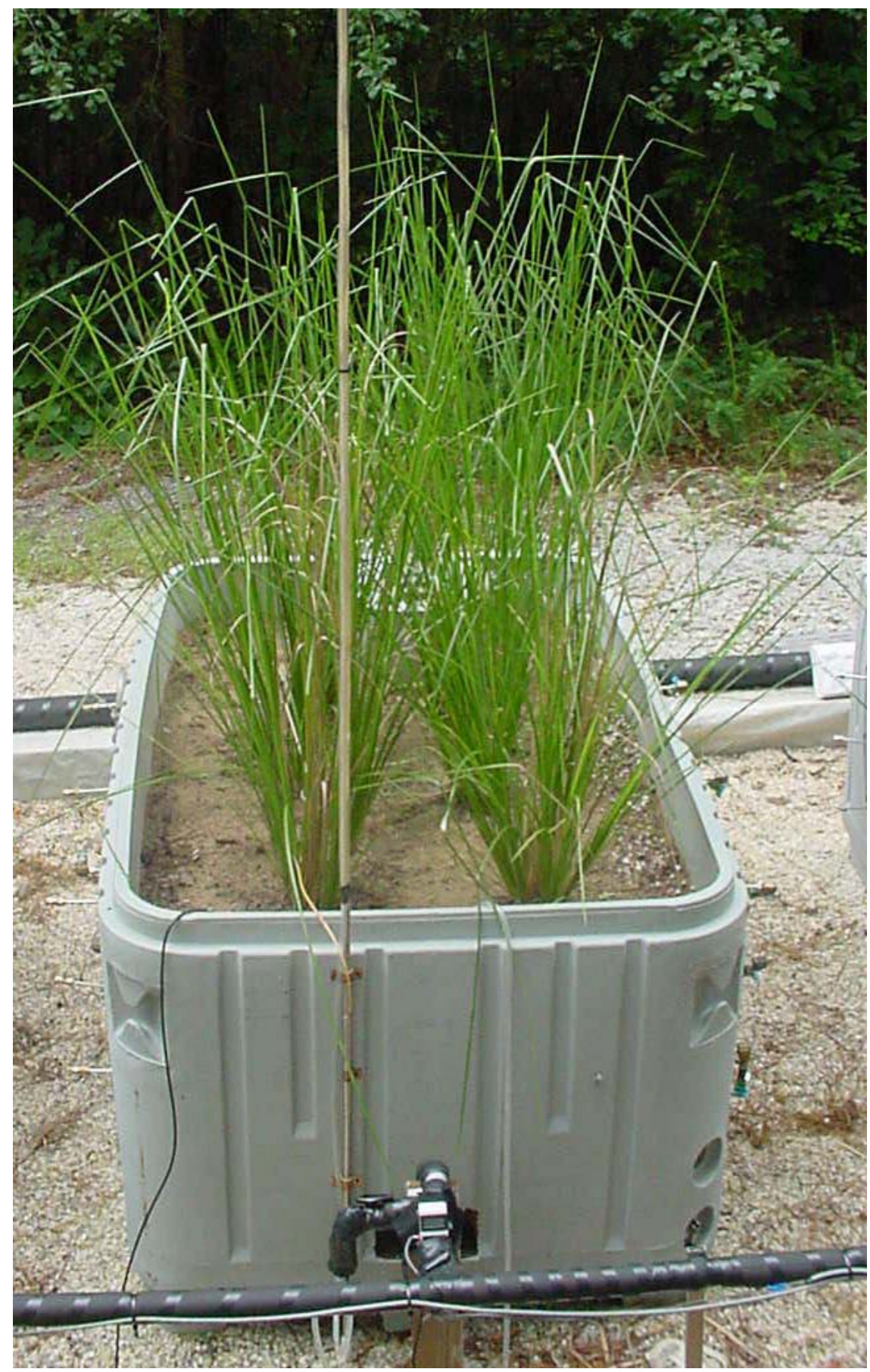

Figure 2d. Setup of Phytoreactor 4 with Vetiver Grass at MSB 88C 
FY 01 Phytoremediation of Chlorinated Ethenes in

WSRC-TR-2001-00437

Southern Sector Sediments of Savannah River Site

Revision 0

Savannah River Site

Page 16 of 62

November 2001

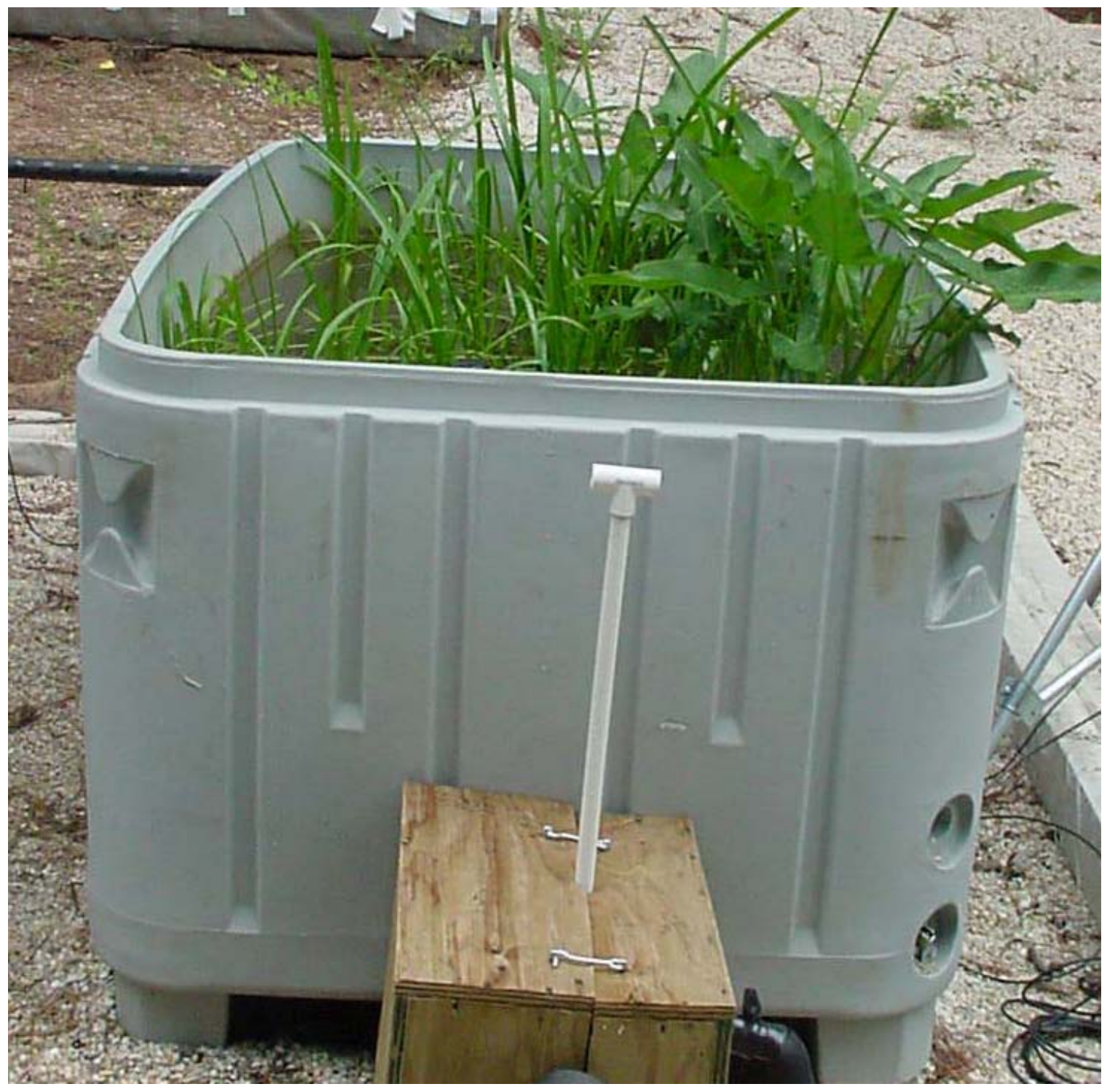

Figure 2e. Setup of Phytoreactor 5 with Wetland System at MSB 88C 
8 inches below the surface of the box and 10 inches above the sediment. Plants in this phytoreactor were allowed to naturally emerge from the wetland sediments. Within one month of initiation, the system was doing well with several plant types emerging. Plant types include a cattail type grass, "burr-reed” (Sparganium americanum); a morning glory-type individual called "lizards tail” (Saururus cernuus); a thin-leaved spreading species, "alligator weed" (Alternanthera philoxeroides)- a grass-type "maiden cane" (Panicum hemitomon); and an arrowhead leaf individual commonly known as "arrow arum” (Peltandra virginica). This first year the $P$. virginica and $A$. philoxeroides dominated the growth in the phytoreactor.

\section{$\underline{\text { 2.1.1.8 } \quad \text { Weather Station }}$}

A Dynamet ${ }^{\mathrm{TM}}$ stand-alone, weather station was installed at the site to support the Southern Sector Phytoremediation Project. In the fall of 2000 (FY01), the solar-powered, field-deployable weather station with an optional soil-moisture probe was purchased from Dynamax Inc. The weather station was initially assembled and installed at TNX to provide timely access during equipment familiarization, system startup and operation. This proved to be beneficial since early operational problems required continual access to the equipment. Once normal system operation was established and the user interface understood, the station was relocated to the Southern Sector MSB 88C site in the spring of 2001.

The weather station continually monitors eight environmental parameters (average air temperature, average soil temperature, solar radiation, wind speed, wind direction, rain fall, organic soil moisture, and mineral soil moisture), two internal system parameters (data logger temperature and battery voltage), and the time and date. Each environmental parameter is calculated and/or summed and recorded hourly on an internal data logger. The data is recorded in a comma-delineated American Standard Code for Information Interchange (ASCII) file, which is accessible and down-loadable using a laptop personal computer with software supplied with the weather station. The software provides 
standard report formats; however the data is easily accessible by Microsoft Excel and hence can be evaluated, manipulated, and combined with other relevant data by the user.

\subsubsection{Startup}

On March 20, 2001, modifications were completed and all phytoreactors were placed in operation, receiving contaminated groundwater in the new configuration. The flow rates were initially adjusted to around $20 \mathrm{~mL} / \mathrm{min}$.

\subsubsection{Sample Collection}

Sampling groundwater from the phytoreactors for chemical and microbial analysis began on March 30, 2000. The phytoreactors were sampled monthly for groundwater influent and effluent microbial activity, VOCs, and ion analysis. Plant tissue samples were taken in July 2001.

\subsubsection{Flow measurements}

The influent flow rates for the phytoreactors were collected using a digital flow meter and a data logger (Campbell Scientific Inc.) powered by a solar cell. While the Savannah River Technology Center (SRTC) assisted in setup of the system, GT was responsible for weekly monitoring and down loading the flow data. The flow rates for each phytoreactor were logged every fifteen minutes. This fifteen-minute value represented the average flow rate over that particular time period.

\subsubsection{Gas Chromatography}

Samples were taken monthly from phytoreactor groundwater influent and effluent for VOC analysis. Soil samples were collected by hand auger from four locations in each phytoreactor, two shallow (1.64 feet) and two deep (3.28 feet). Each soil sample was collected with a modified plastic syringe and placed directly into a $20 \mathrm{~mL}$ glass vial with $5 \mathrm{~mL}$ deionized water and immediately sealed for subsequent VOC analysis. Chlorinated ethene analysis was performed on samples in sealed glass vials using headspace gas 
chromatography (GC). The headspace GC method minimizes sample handling and preparation and measures the bulk VOC content of the sample. Samples were analyzed using a Hewlett-Packard 5890 GC equipped with a flame ionization detector (FID) and a 60-m SPB1 ${ }^{\mathrm{TM}}$ column (0.75-mm inner diameter (ID), 1- $\mu \mathrm{m}$ thick; Supelco, Bellefonte, PA).

\subsubsection{Soil-Gas Determination}

Stainless-steel equilibration chambers were set up with a photoaccoustic multigas monitor (Innova AirTech Instruments Model 1312, Denmark) to measure soil-gases in the phytoreactors. This method measures the rates of soil carbon dioxide production and moisture content as well as PCE and TCE concentrations. These measurements were made in August 2001 when the trees were fully developed. Two series of measurements were taken from each phytoreactor. Soil-gas measurements also were taken from a control area in the woods 16.4 feet to the south of the site. At the same time soil-gas samples were taken for manual injections from a Tedlar gasbag with a $250-\mu \mathrm{L}$ gas-tight syringe (Precision Scientific, Baton Rouge) for testing on a GC.

\subsubsection{Transrespiration Measurements}

For transrespiration gas, large (25 L) Tedlar gasbags were used to cover and seal large areas of plants to measure VOC phytovolatilization. Plant sections were covered for 30 minutes and multiple gas samples taken and placed in 2-L Tedlar gasbags. Samples from Tedlar gasbag samples were taken to the lab and processed the same day. Gas samples were injected into the GC with a $250-\mu \mathrm{L}$ gas-tight syringe.

\subsubsection{Plant Tissue Analysis}

In July 2001, plant tissues (roots, stems, and leaves) from the pine, poplar, Vetiver, and select wetland species were taken from the analysis of PCE, TCE and potential metabolic breakdown products, including trichloroacetic acid (TCA) and dichloroacetic acid (DCA). Plant samples taken from Phytoreactor 5, the wetland system, were the 
“dominant" species at the time since they appeared to make up most of the biomass, including the thin-leaved spreading species "alligator weed" (A. philoxeroides) and arrowhead leaf known as "arrow arum" (P. virginica). This analysis provides useful information on the fate of the chlorinated ethenes in the plants. The plant tissue samples for VOC testing were obtained in the field, sealed in $20 \mathrm{~mL}$ GC vials, and immediately processed as described by Vroblesky et al. (1999). Plant samples for metabolite analysis were placed on dry ice in the field and brought back to the laboratory where they were stored at $-70^{\circ} \mathrm{C}$ until processing. Plant samples were then processed and tested for metabolites as described by Newman et al. (1999).

\subsubsection{Microcosm Studies}

Microcosm tests were set up at SRS to assess the microbial activity and ability of seepline soils and wetland sediments to transform PCE, TCE, and daughter products. Anaerobic microcosms were established to evaluate the potential for indigenous microorganisms to dechlorinate PCE, TCE, cis-DCE, and VC to subsequent end products. Resazurin was used as a redox indicator. The dye remains colorless when reduced and becomes pink when oxidized, thus quickly indicating any oxygen contamination of the microcosm. The electron acceptor (chlorinated compound) employed was TCE. Anaerobic microcosms are being used to assess activity for transformation of TCE to degradation products as well as the presence of bacterial populations indicative of other favorable bioprocesses (e.g., halorespiration and methanogenesis). This experimental approach determines potential necessary enhancements (i.e., carbon-source/nutrients) to promote the microbial degradation of TCE and daughter products (i.e., c-DCE and VC). Results from this study can be used to evaluate applicable field methods for bioremediation with the contaminated seepline.

Microcosms were prepared using rhizosphere soils from the seepline, wetlands (UTRC), and groundwater obtained from MSB 88C. Since the soils were used directly and not screened or sorted, the associated root material was included. After collection, soil and 
groundwater were transferred immediately to the EBS laboratory at the TNX area at SRS where all subsequent handling was in an anaerobic glovebox $\left(5 \% \mathrm{H}_{2} / 5 \% \mathrm{CO}_{2} / 90 \% \mathrm{~N}_{2}\right)$.

The study consists of three sets of microcosms per sample: (1) live, active microcosms with varying nutrient amendments and a TCE amendment; (2) live control microcosms with TCE but without nutrient amendments; and (3) killed control microcosms (with nutrient amendments and TCE amendment). The killed controls had microbial activity stopped by autoclaving soil, filter-sterilized groundwater, and sodium azide addition. Nutrient amendments to be tested include low cost soybean oil and a commercial fertilizer $\left(\right.$ Osmocote $\left.{ }^{\circledR}\right)$.

Microcosms were assembled in sterile glass 240-mL serum bottles sealed with screw cap mininert valves. Each test microcosm was prepared with approximately 50 grams (wet weight) cored sediment and MSB 88C groundwater with varying nutrient amendment(s) and TCE (1,000 ppb). Liquid components of each microcosm totaled $100 \mathrm{~mL}$. The groundwater was used unfiltered and unsterilized (except in killed controls) and was “degassed" by stirring in the anaerobic chamber overnight before it was added to microcosms. Resazurin (1 $\mathrm{mg} / \mathrm{L})$ was added to groundwater as an indicator of anaerobiosis. Cored sediments were mixed for homogeneity in the controlled atmosphere of an anaerobic glovebox before they were added to the microcosms. The microcosms were assembled in an anaerobic glovebox using aseptic techniques. The fertilizer amendment added was Osmocote ${ }^{\circledR}$ (Scotts-Sierra Horticultural Products Co., Marysville, $\mathrm{OH})$, a slow release fertilizer, which is $14-14-14$. One bead of Osmocote ${ }^{\circledR}$ was added to each microcosm. The beads were found to weigh on the average 32 milligrams each. The soybean oil and fertilizer amendments were $0.5 \%$ of the total liquid volume. Sodium azide $(0.1 \%)$ was added to autoclaved groundwater in the killed control microcosms. Sediments and groundwater used in killed control microcosms were autoclaved three times over seven days before microcosm preparation. All microcosms are shielded from light in the anaerobic hood at $25^{\circ} \mathrm{C}$. 
After six weeks, $1 \mathrm{~mL}$ samples from the microcosms were withdrawn through the mininert valves and added to $9 \mathrm{~mL}$ of distilled water in a GC vial, capped, and analyzed for VOCs. The concentration of VOCs was determined by analysis of headspace samples from the vials using a GC mass spectrometry (MS) as previously described.

\subsubsection{Ion Chromatography}

Anion and cation groundwater and sediment concentrations were measured with a Dionex DX500 ion chromatograph equipped with a conductivity detector and a 250-mm Dionex IonPac AS14 Analytical column (4-mm ID, 16- $\mu$ m bead; Dionex Corp., Sunnyvale, CA), operated at ambient temperatures. A 3.5 millimolar (mM) sodium carbonate/1 mM sodium bicarbonate buffer solution was used as the eluent $(1.2 \mathrm{~mL} / \mathrm{min})$. Samples were taken from the supernatant of a solution prepared from groundwater or $5 \mathrm{~g}$ of dry soil (dried at $121^{\circ} \mathrm{C}$ for 24 hours) and 5-mL of deionized water, vortexed for 1 minute, and then centrifuged for 5 minutes at 2,500 revolutions per minute (rpm).

\subsubsection{Microbial Densities}

Comprehensive analysis of specific microbial populations and characterization of the metabolic activity of whole microbial communities can be an effective tool to predict the bioremediation potential of a natural system. These analyses monitor the activity of specific microorganisms in reducing and/or removing harmful groundwater contaminants. In this project groundwater samples were collected in sterile 50-mL centrifuge tubes and transported to the laboratory for immediate microbiological processing. Sediment samples were collected with a stainless steel auger and handled aseptically for subsequent analysis. Total microbial population densities in phytoreactor influent and effluent groundwater and soils were determined by the Acridine Orange Direct Count (AODC) Method (Balkwill 1989). The viable microbial population densities of aerobic and facultative heterotrophic bacteria in groundwater and soils were determined using spread plate techniques. Low concentrations (1\%) of PeptoneTrypticase-Yeast extract-Glucose (PTYG) media were used (Balkwill 1989). 


\subsection{FY01 STUDY RESULTS}

\subsection{Results}

\subsubsection{Weather Station}

Attached is a graph of selected data collected at the Southern Sector phytoremediation site during the summer of 2001 (Figure 3). The data represented are self explanatory except for the organic and mineral soil-moisture values. These parameters are determined by measuring the soil dielectric constant and converting it to percent moisture. One soil moisture probe was provided with the weather station and that was placed in Phytoreactor 4. The soil moisture stayed steady throughout the year, indicating the constancy of the groundwater flow of the system. The few fluctuations in soil moisture were correlated to rainfall events. Swings in humidity levels from night to day were greater in the spring. The rainfall was spread out through the summer. Temperature peaks were also distributed throughout the summer. There were no major heat waves or inversions during this summer. Although the weather station can be programmed for site-specific soil moisture conversions, the generalizations used by the weather station are valid for most soil types.

\subsubsection{Flow Measurements}

Groundwater supplying the phytoreactors is measured with flowmeters (Model S-111-3, McMillan Co., Dallas, TX) interfaced with a datalogger powered by solar cells. The phytoreactors were set up in March 2001 with an influent of $20 \mathrm{~mL}$ groundwater per min ( 7.6 gal/d) similar to last year. The flow rate was found to constantly change as a result of soil settling, weather conditions, and plant growth and root development. Plots of data from Phytoreactors 1, 2, and 3 are included to demonstrate the variability in the flow data (Figures 4 a through e). From observing the data in Figures 4a-e, Phytoreactors 1 and 5 appeared to have flow problems. Phytoreactor 1 appeared to have good flow when physically checked in the field so the problem could have been the flow meter. Phytoreactor 5 was the wetland system and settling may have inhibited adequate flow. 


\section{Weather Station Data}

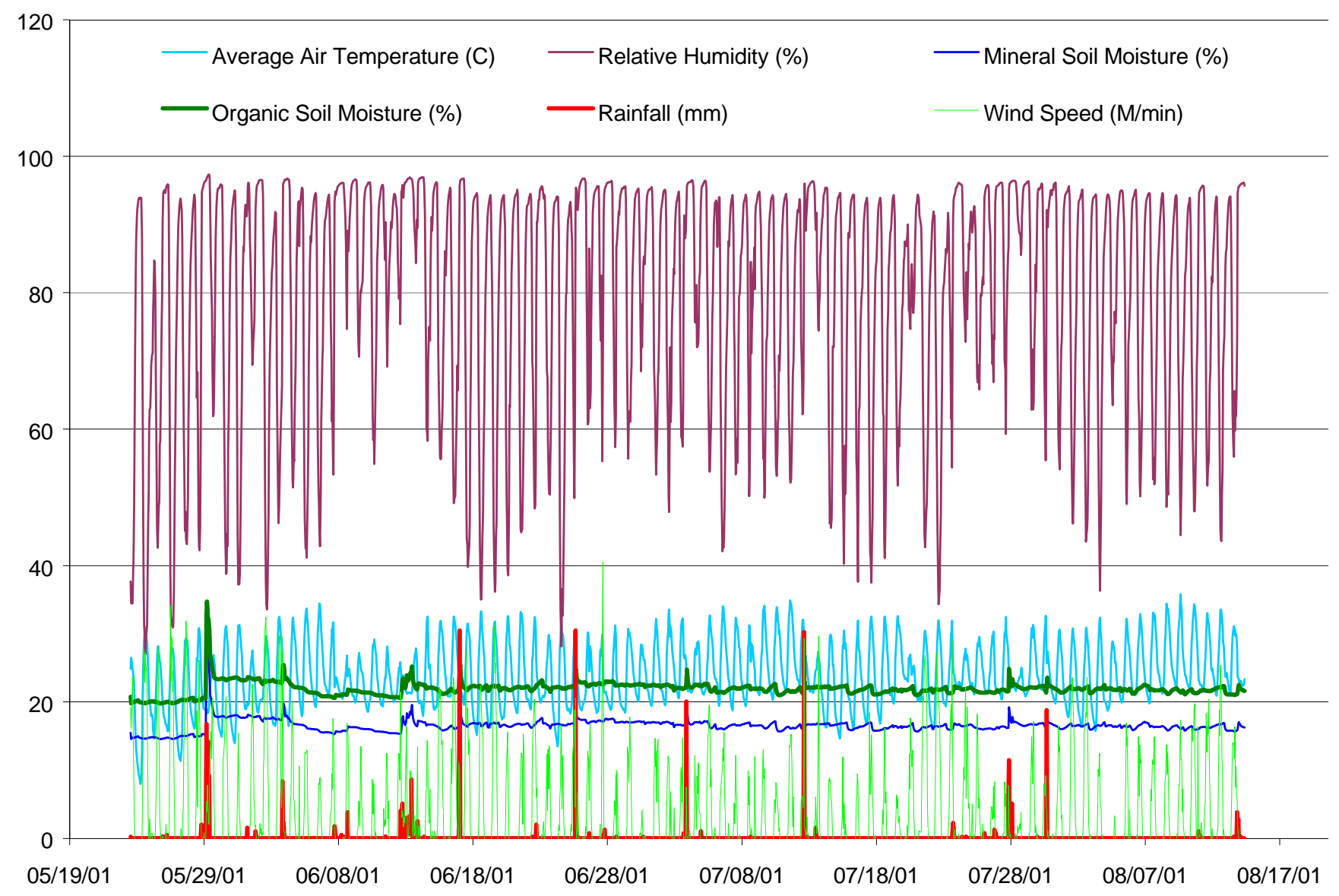

Figure 3. Weather Data from Vicinity of MSB 88C for summer of 2001 
FY 01 Phytoremediation of Chlorinated Ethenes in

WSRC-TR-2001-00437

Southern Sector Sediments of Savannah River Site

Revision 0

Savannah River Site

Page 25 of 62

November 2001

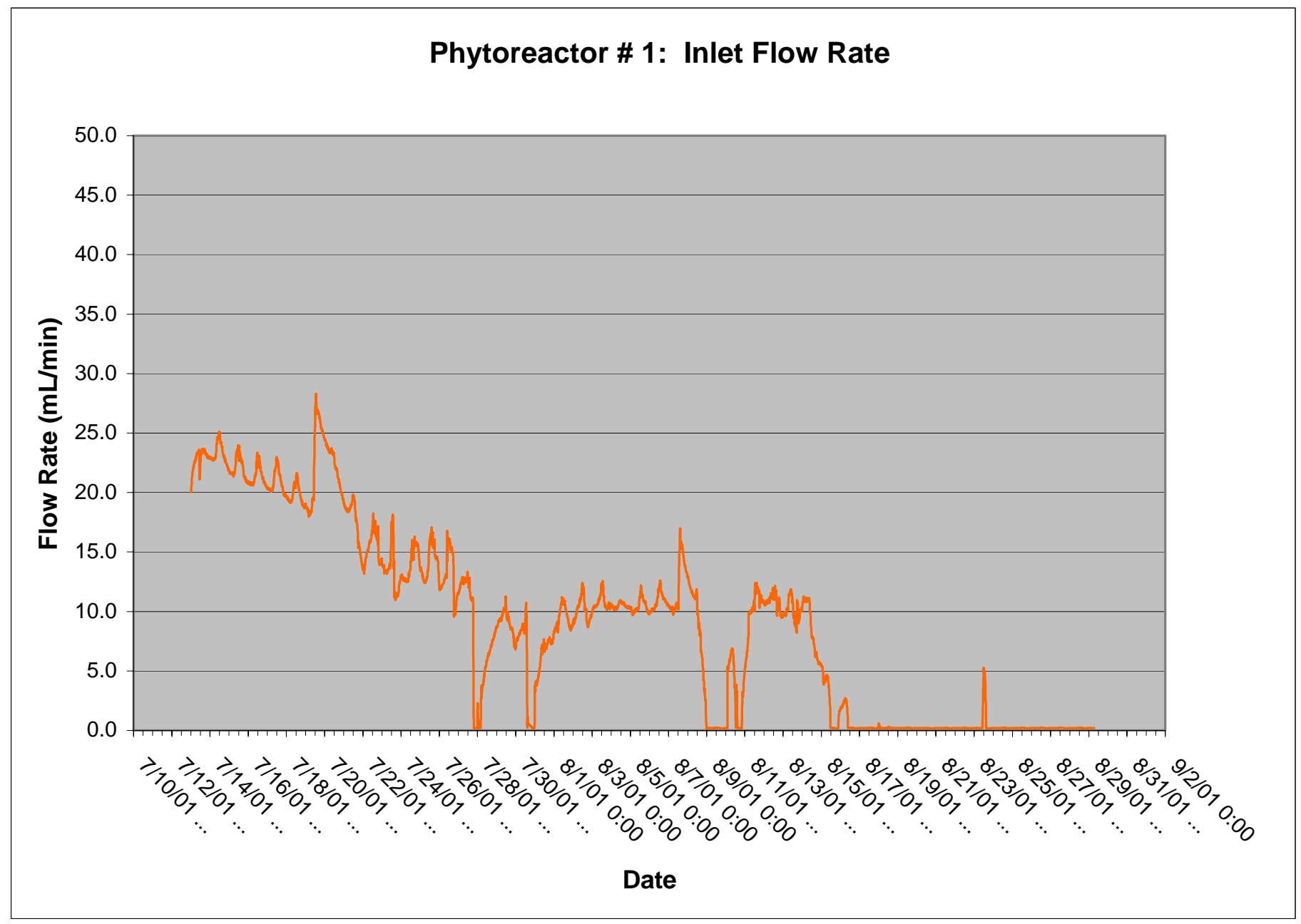

Figure 4a. Groundwater Influent Flow Data for Phytoreactor 1 
FY 01 Phytoremediation of Chlorinated Ethenes in

WSRC-TR-2001-00437

Southern Sector Sediments of Savannah River Site

Revision 0

Savannah River Site

Page 26 of 62

November 2001

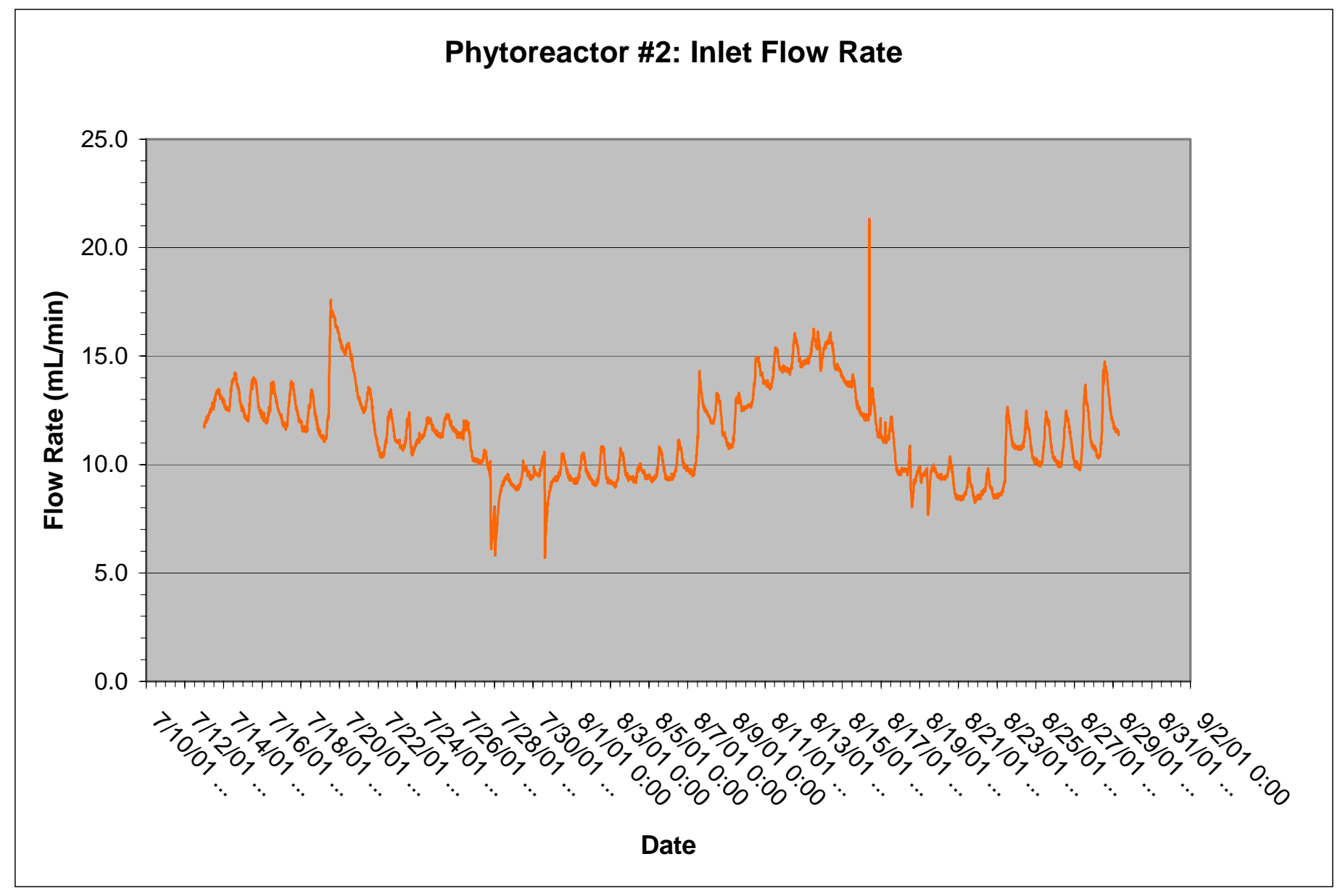

Figure 4b. Groundwater Influent Flow Data for Phytoreactor 2 
FY 01 Phytoremediation of Chlorinated Ethenes in

WSRC-TR-2001-00437

Southern Sector Sediments of Savannah River Site

Revision 0

Savannah River Site

Page 27 of 62

November 2001

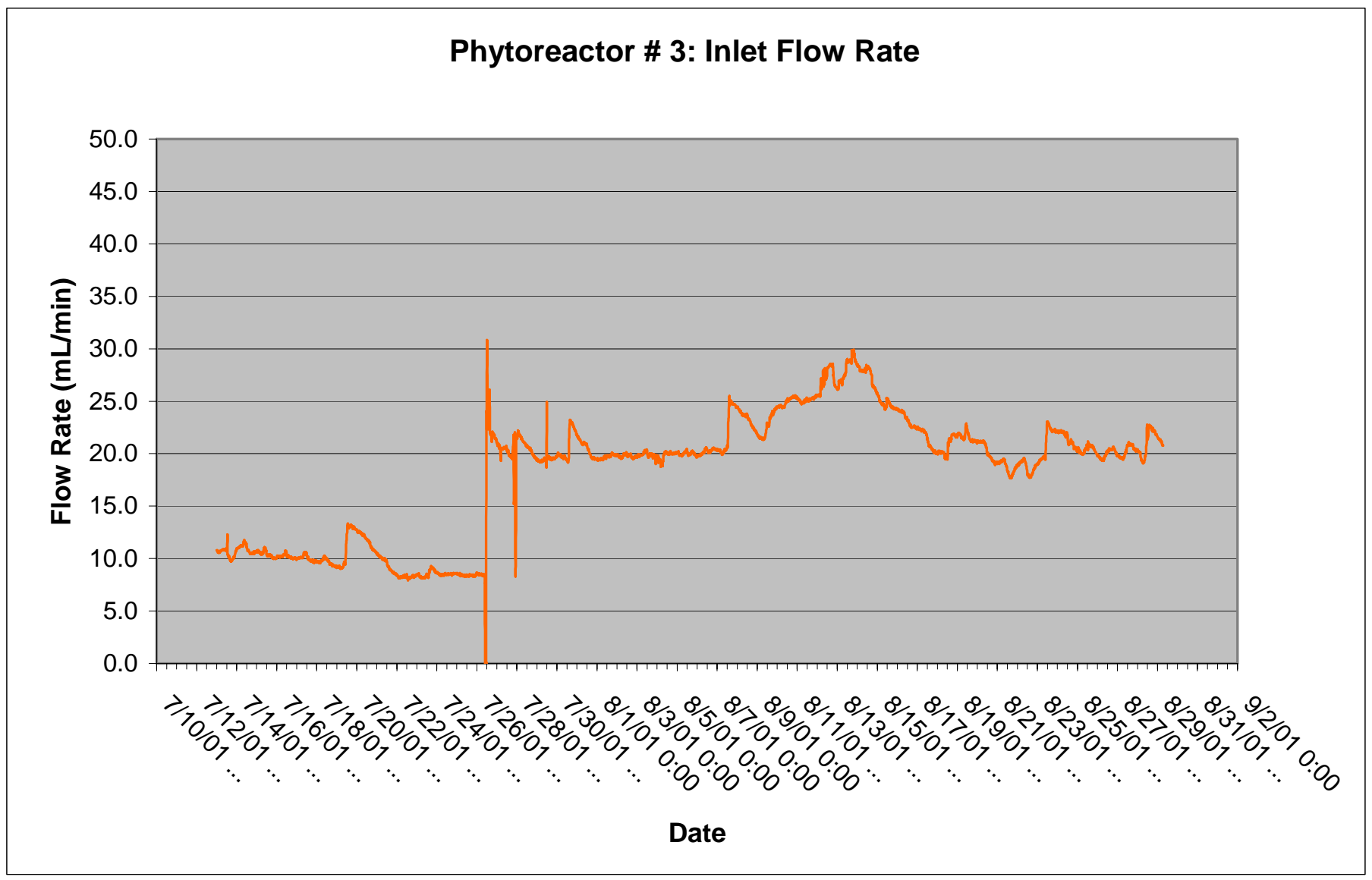

Figure 4c. Groundwater Influent Flow Data for Phytoreactor 3 
FY 01 Phytoremediation of Chlorinated Ethenes in

WSRC-TR-2001-00437

Southern Sector Sediments of Savannah River Site

Revision 0

Savannah River Site

Page 28 of 62

November 2001

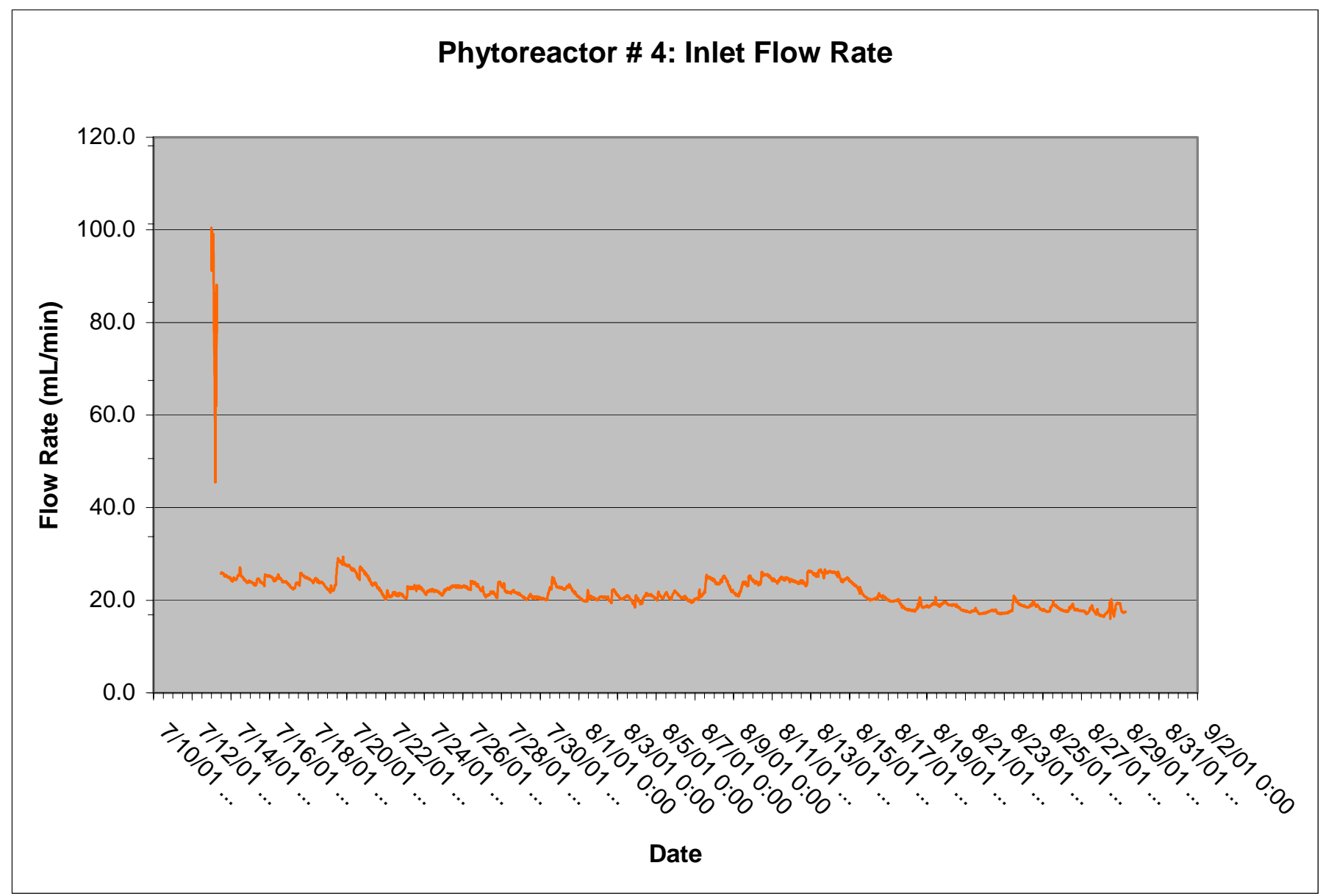

Figure 4d. Groundwater Influent Flow Data for Phytoreactor 4 
FY 01 Phytoremediation of Chlorinated Ethenes in

WSRC-TR-2001-00437

Southern Sector Sediments of Savannah River Site

Revision 0

Savannah River Site

Page 29 of 62

November 2001

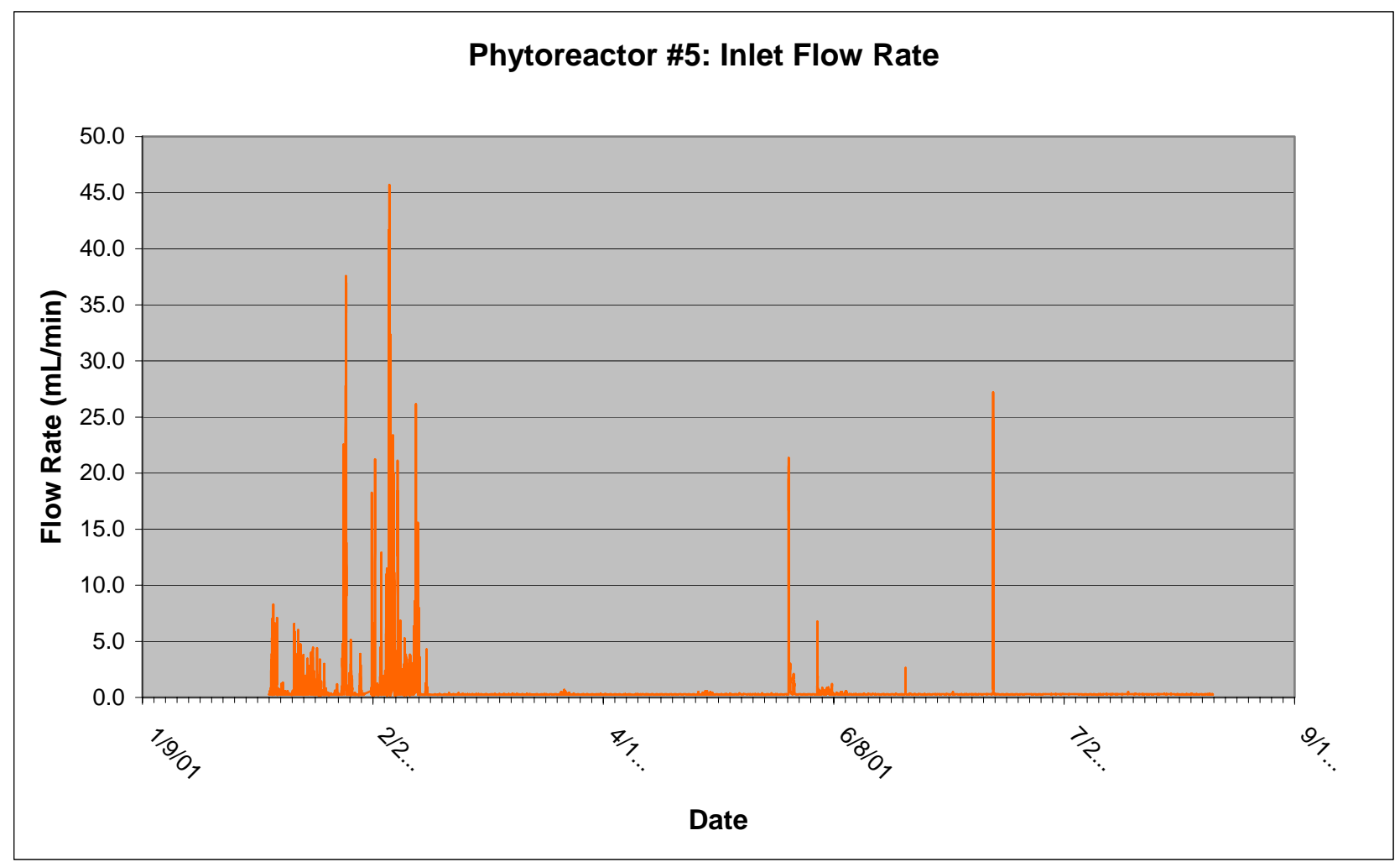

Figure 4e. Groundwater Influent Flow Data for Phytoreactor 5 
There are peaks in flow rate when the supply tank is filled but the Marriotte system seems to have reduced the variability of the tank filling effect compared to last year (WSRC 2000a).

\subsubsection{Removal of TCE and PCE from Groundwater}

When the supply tank was filled, it was found that well MSB 88C had decreased TCE and PCE groundwater concentrations. This was confirmed by MSB 88C groundwater monitoring data (Figure 5) supplied by Geochemical Information Management System (GIMS). The phytoreactors actually received the continuous flow of contaminated groundwater with concentrations averaging around 30 ppb TCE and 20 ppb PCE for this year (Figures 6 through 9). Concentrations of TCE and PCE in the phytoreactor influent and effluent groundwater are shown in Figures 6 through 11, respectively. All five phytoreactors show a reduction in both TCE and PCE groundwater concentrations in the effluent as compared to the influent. In April and May, when the phytoreactors were becoming established, some PCE or TCE was found in most of the effluent groundwater (Figures 6 and 7). By the June and July 2000 sampling events, much less TCE and PCE was evident in the effluent (Figures 8 and 9), with total removal by July in Phytoreactor 2 containing poplars and Phytoreactor 5 containing wetland species (Figure 9). In June and July, samples were taken for soil volatilization and plant transrespiration. No detectable TCE or PCE ( $<5 \mathrm{ppb})$ was found in soil volatilization from any of the phytoreactors.

Groundwater data analysis in Figure 10 shows the differences between each pair of influent and effluent measurements for each of the five phytoreactors for TCE. In addition, because the Shapiro-Wilks test statistics indicated that the data for both of these constituents adhered to the assumption of normality, an Analysis of Variance (ANOVA) was performed and followed by a Dunnett's test (Daniel 1978). The latter test allows for pairwise comparisons between the control (Phytoreactor 3) and each of the other four treatment phytoreactors. The ANOVA test results indicated that there are significant $(\mathrm{p}=$ .05) differences in TCE concentration among the five treatment phytoreactors. However, 
FY 01 Phytoremediation of Chlorinated Ethenes in

WSRC-TR-2001-00437

Southern Sector Sediments of Savannah River Site

Revision 0

Savannah River Site

Page 31 of 62

November 2001

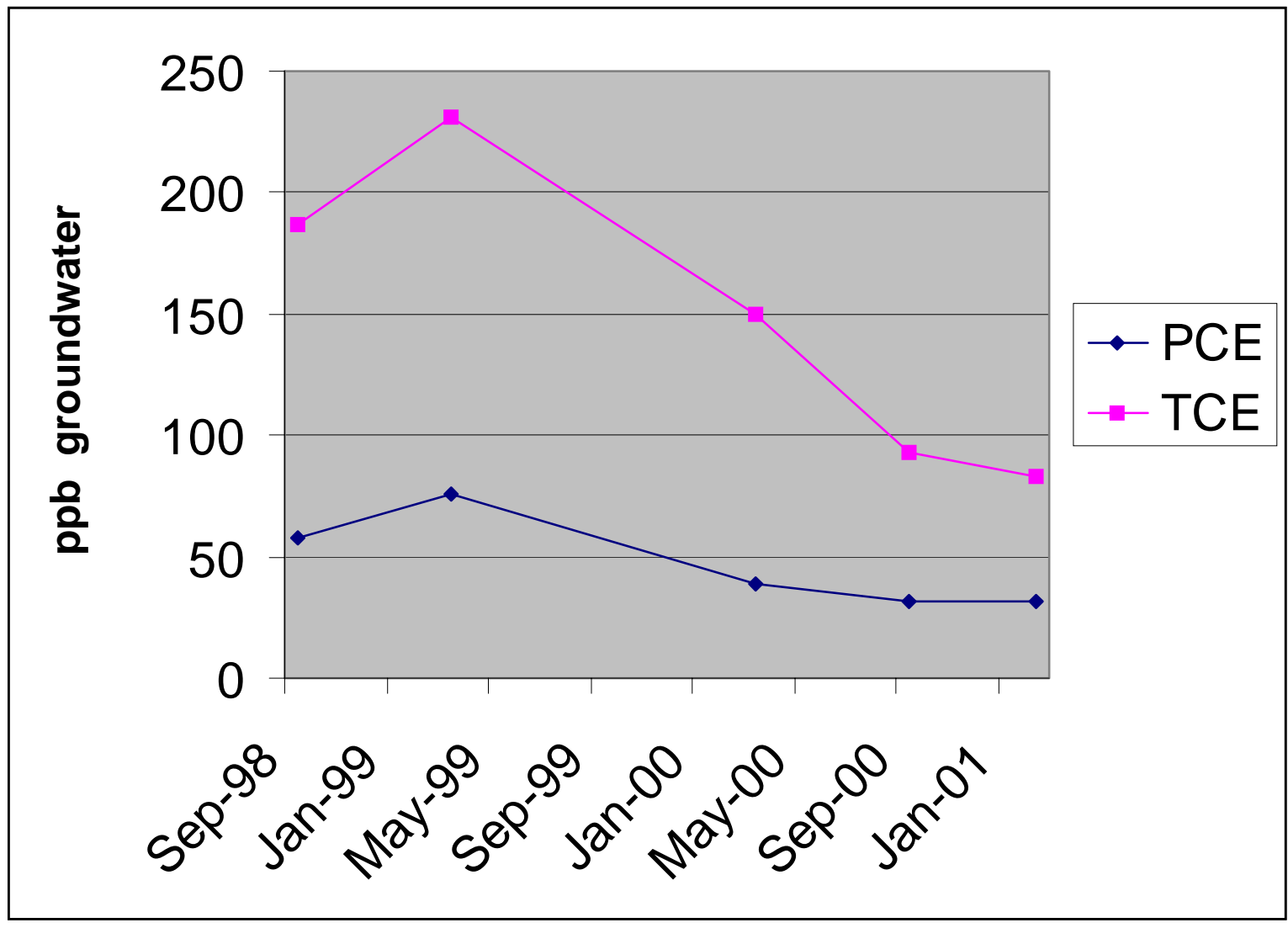

Figure 5. TCE and PCE Groundwater Concentrations in MCB 88C from September 1998 until January 2001 (Source: GIMS) 
FY 01 Phytoremediation of Chlorinated Ethenes in

WSRC-TR-2001-00437

Southern Sector Sediments of Savannah River Site

Revision 0

Savannah River Site

Page 32 of 62

November 2001

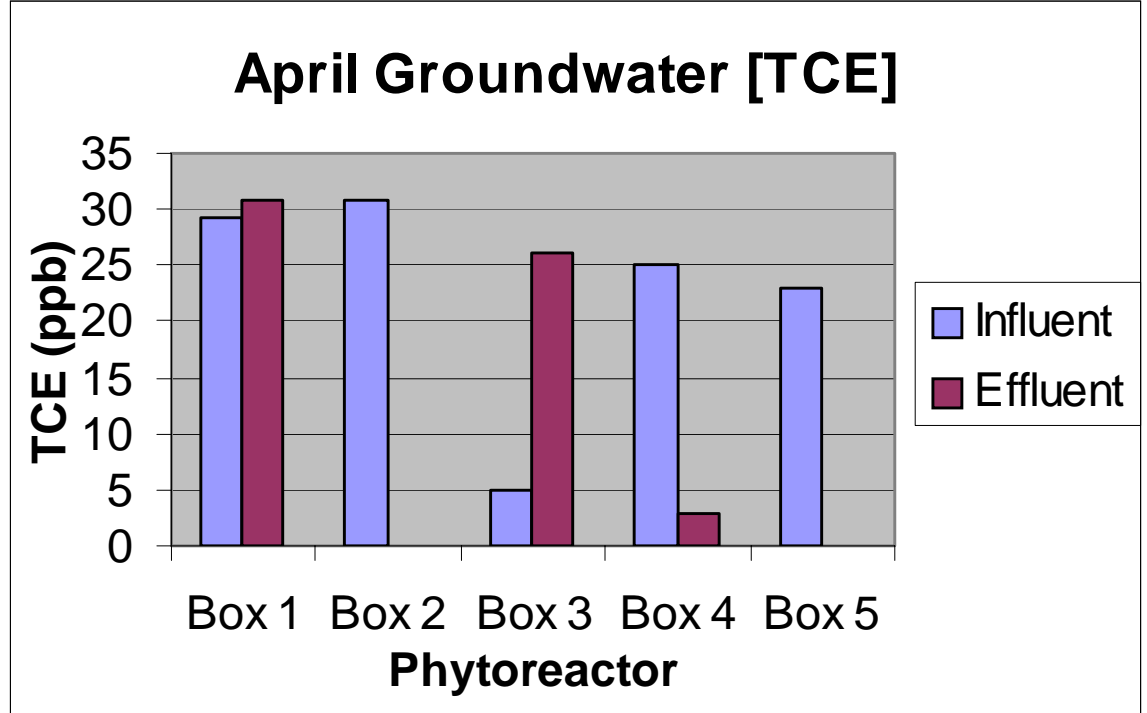

Figure 6a. April 2001 Groundwater TCE Data for Phytoreactors 1 through 5

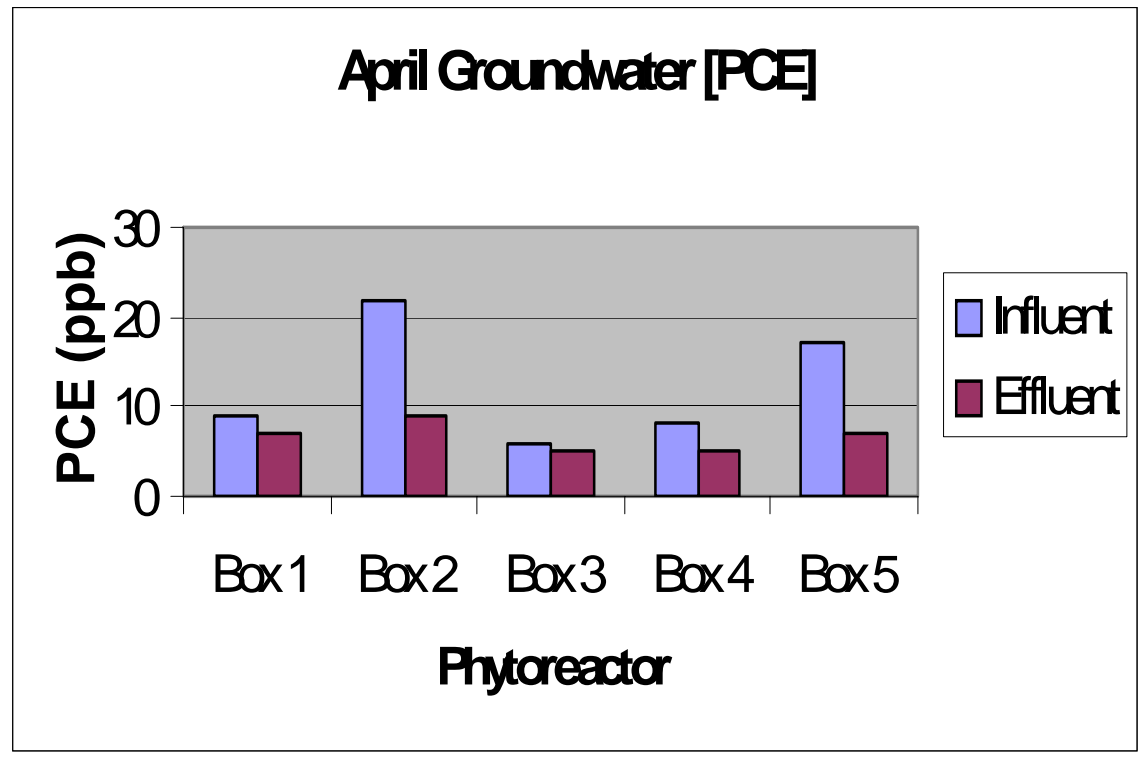

Figure 6b. April 2001 Groundwater PCE Data for Phytoreactors 1 through 5 
FY 01 Phytoremediation of Chlorinated Ethenes in

WSRC-TR-2001-00437

Southern Sector Sediments of Savannah River Site

Revision 0

Savannah River Site

Page 33 of 62

November 2001

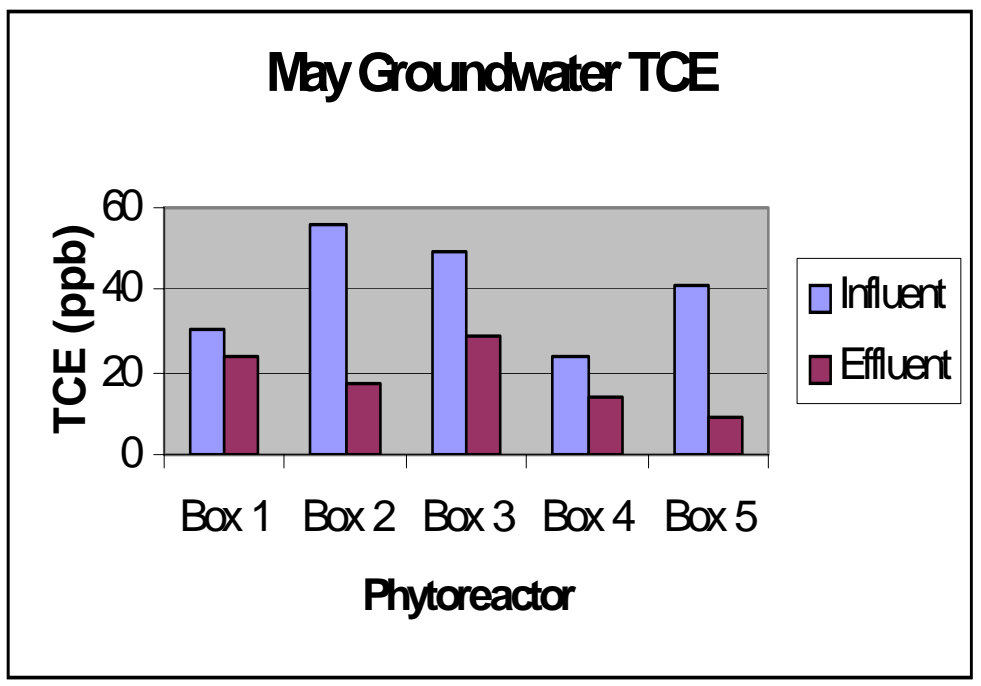

Figure 7a. May 2001 Groundwater TCE Data for Phytoreactors 1 through 5

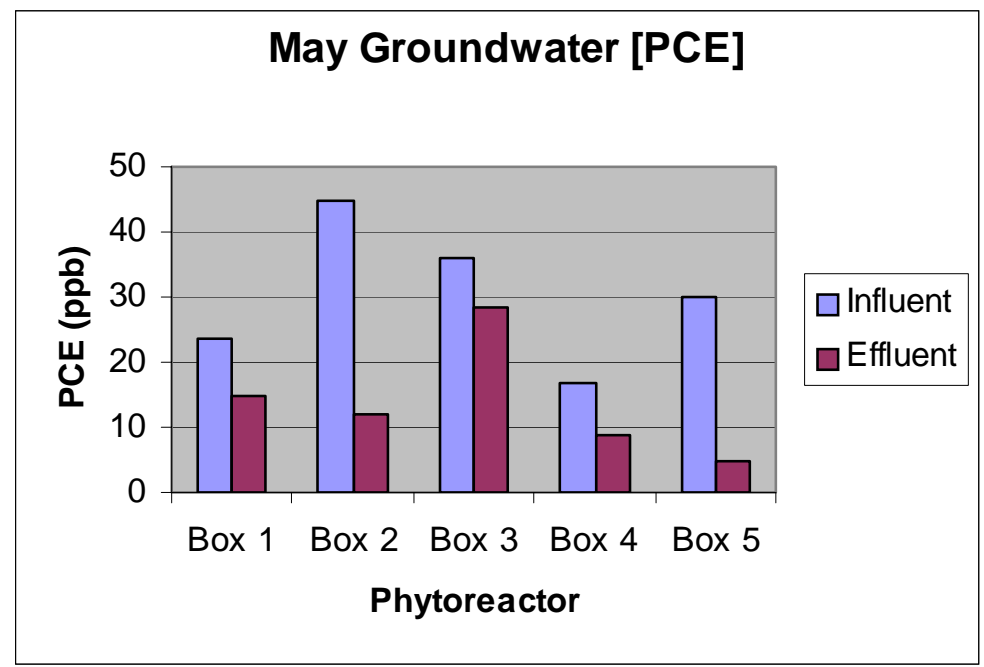

Figure 7b. May 2001 Groundwater PCE Data for Phytoreactors 1 through 5 
FY 01 Phytoremediation of Chlorinated Ethenes in

WSRC-TR-2001-00437

Southern Sector Sediments of Savannah River Site

Revision 0

Savannah River Site

Page 34 of 62

November 2001

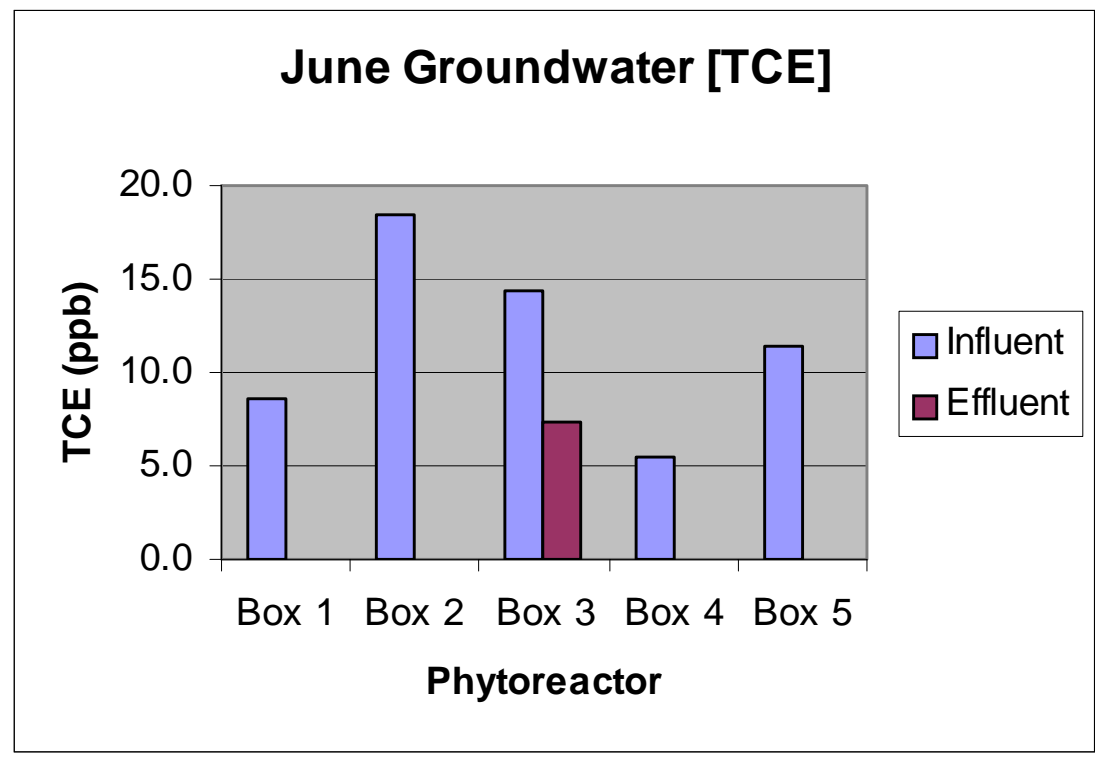

Figure 8a. June 2001 Groundwater TCE Data for Phytoreactors 1 through 5

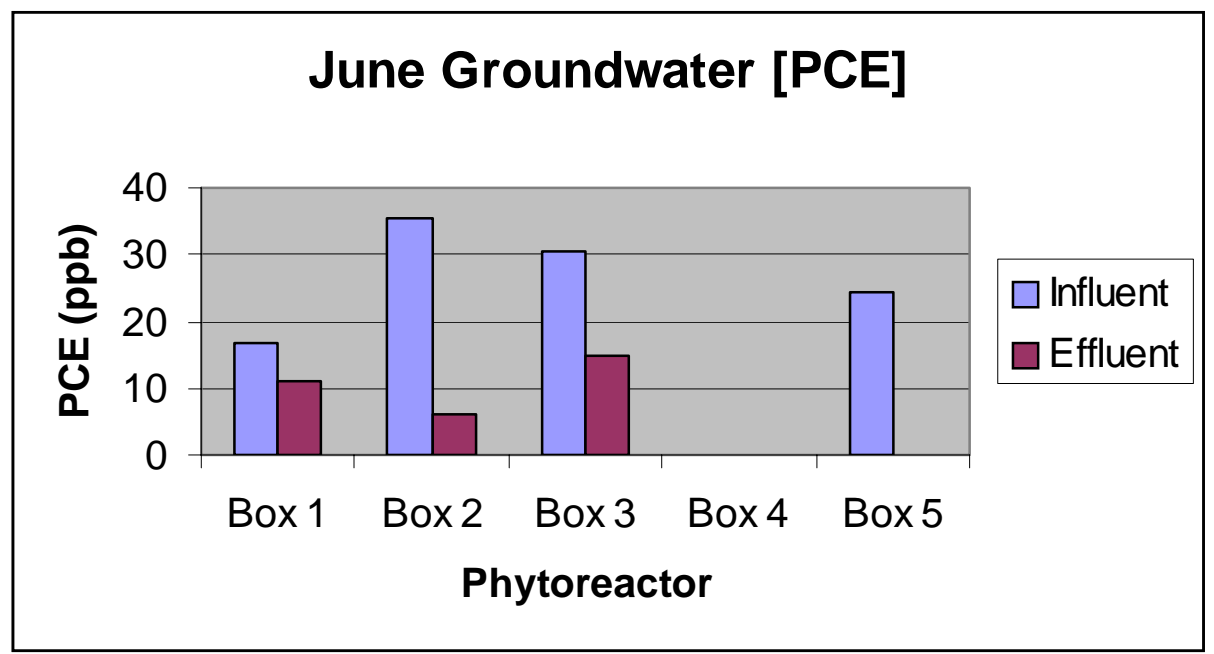

Figure 8b. June 2001 Groundwater PCE Data for Phytoreactors 1 through 5 
FY 01 Phytoremediation of Chlorinated Ethenes in

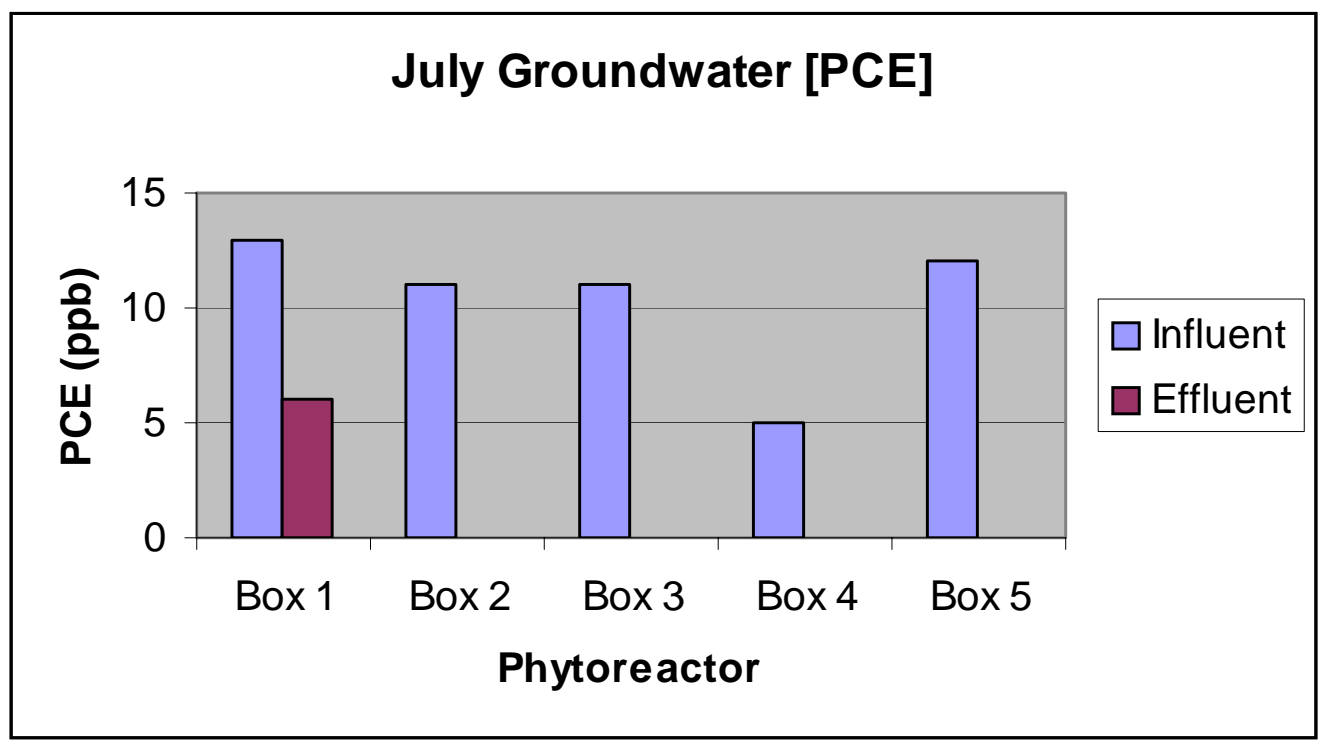

Figure 9a. July 2001 Groundwater TCE Data for Phytoreactors 1 through 5

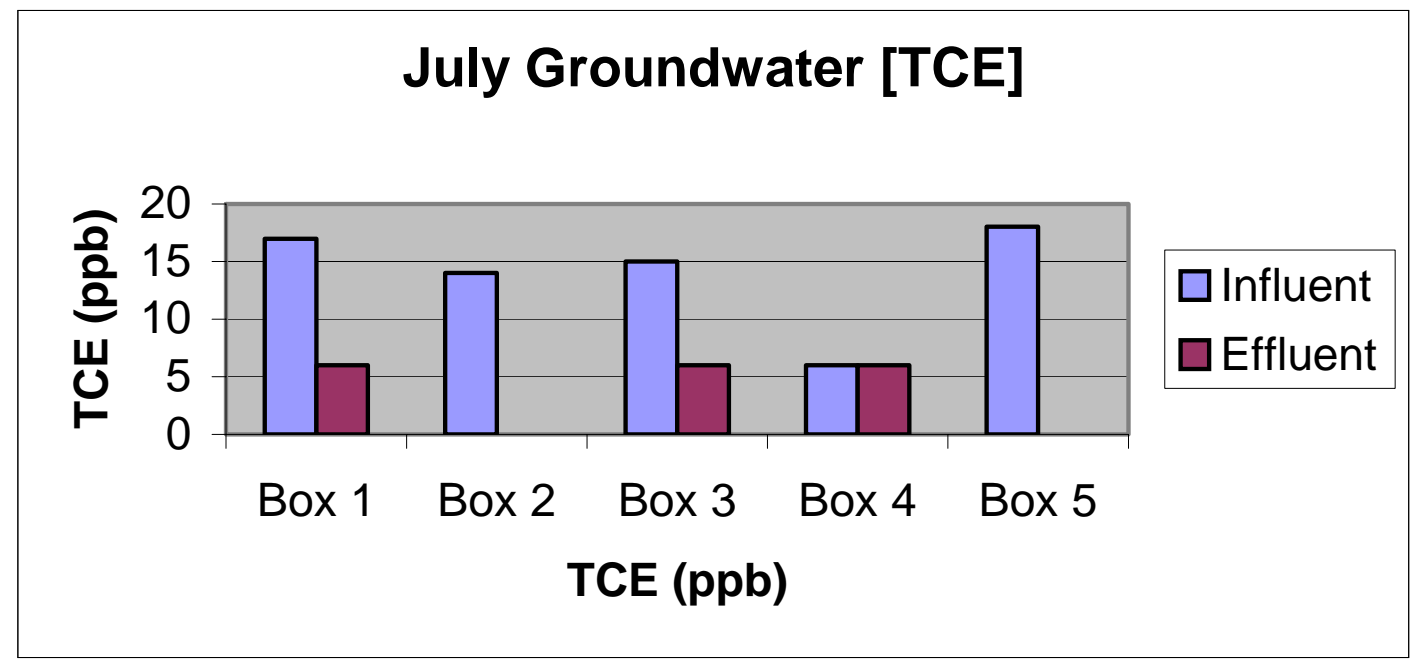

Figure 9b. July 2001 Groundwater PCE Data for Phytoreactors 1 through 5 
FY 01 Phytoremediation of Chlorinated Ethenes in

WSRC-TR-2001-00437

Southern Sector Sediments of Savannah River Site

Revision 0

Savannah River Site

Page 36 of 62

November 2001

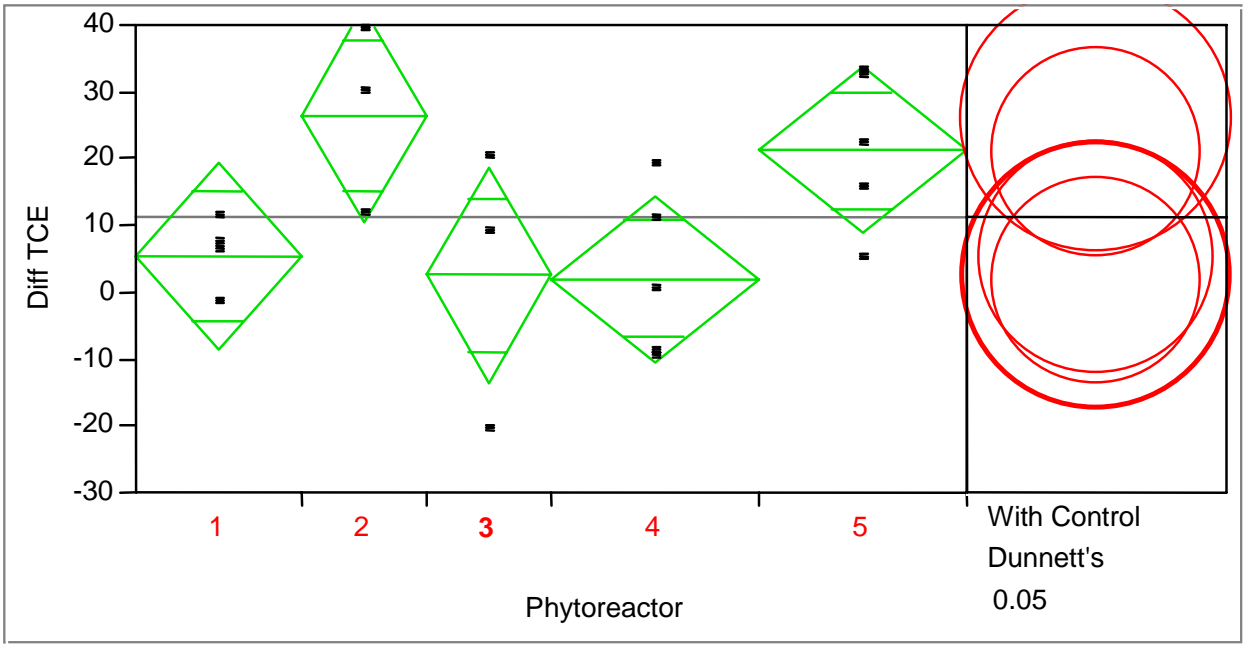

Figure 10. Groundwater Influent and Effluent TCE Concentration $(\mu \mathrm{g} / \mathrm{L})$ Differences for Each of the Five Phytoreactors with Corresponding Dunnett's Test Comparison Circles

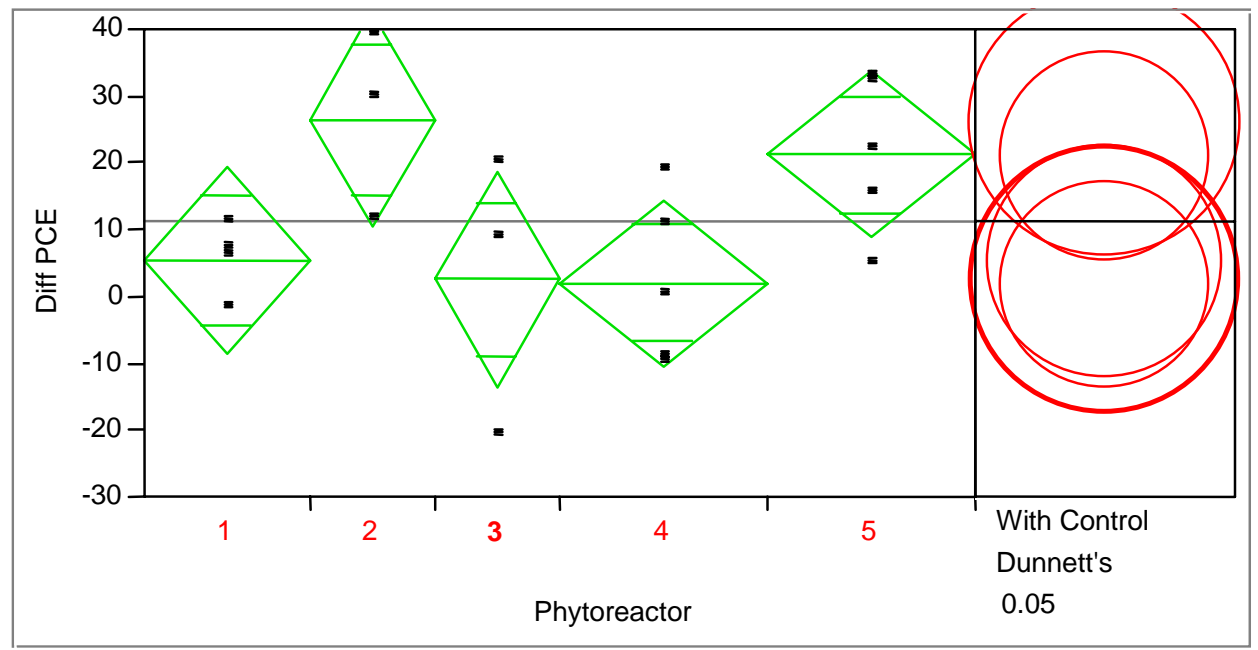

Figure 11. Groundwater Influent and Effluent PCE Concentration ( $\mu \mathrm{g} / \mathrm{L})$ Differences for Each of the Five Phytoreactors with Corresponding Dunnett's Test Comparison Circles 
none of the pairwise comparisons to the Phytoreactor 3 were significant as indicated by the comparison circles in Figure 10- they are nearly concentric. The diameter of each circle corresponds to the height of the corresponding diamond for each phytoreactor. The top and bottom of each diamond correspond to the upper and lower $9 \%$ confidence limits on the corresponding phytoreactor mean. In other words, there was a significant difference in all cases between influent and effluent for each phytoreactor. However, the difference between phytoreactors was not significant.

Figure 11 shows the results of the same statistical tests for PCE. Again, the ANOVA test results indicate that there are significant $(\mathrm{p}=.02)$ differences in PCE concentration between the five phytoreactors but no statistically significant pairwise comparisons between Phytoreactor 3 or any of the other treatment phytoreactors. As with TCE, the comparison circles for PCE in Figure 11 are either concentric or overlap substantially with all others. Again, the ANOVA test results indicate that there are significant ( $\mathrm{p}=$ .02) differences in PCE concentration between the five treatment phytoreactors but no statistically significant pairwise comparisons between Phytoreactor 3 or any of the other treatment phytoreactors. As with TCE, there was a significant difference in all cases between influent and effluent for each phytoreactor. However, the difference between phytoreactors was not significant. This would indicate that MNA is the major factor for VOC removal for this treatability study.

\subsubsection{Soil TCE and PCE}

For the most part, soil VOC concentrations were extremely low to non-detect. A typical data analysis by comparing concentration means is not reliable for any of the four constituents measured in the treatment phytoreactor soils. This is because the percentage of measurements at or below the detection limit was $100 \%$, $94 \%$, $56 \%$, and $64 \%$ for 1,1,-DCE, c-DCE, TCE, and PCE, respectively. In this case the data presented in Figure 12 can be considered preliminary and suggestive at best. Figure 12 graphically presents the soil sample results for TCE and PCE only. Note that some measurements crossed 
FY 01 Phytoremediation of Chlorinated Ethenes in

WSRC-TR-2001-00437

Southern Sector Sediments of Savannah River Site

Revision 0

Savannah River Site

Page 38 of 62

November 2001
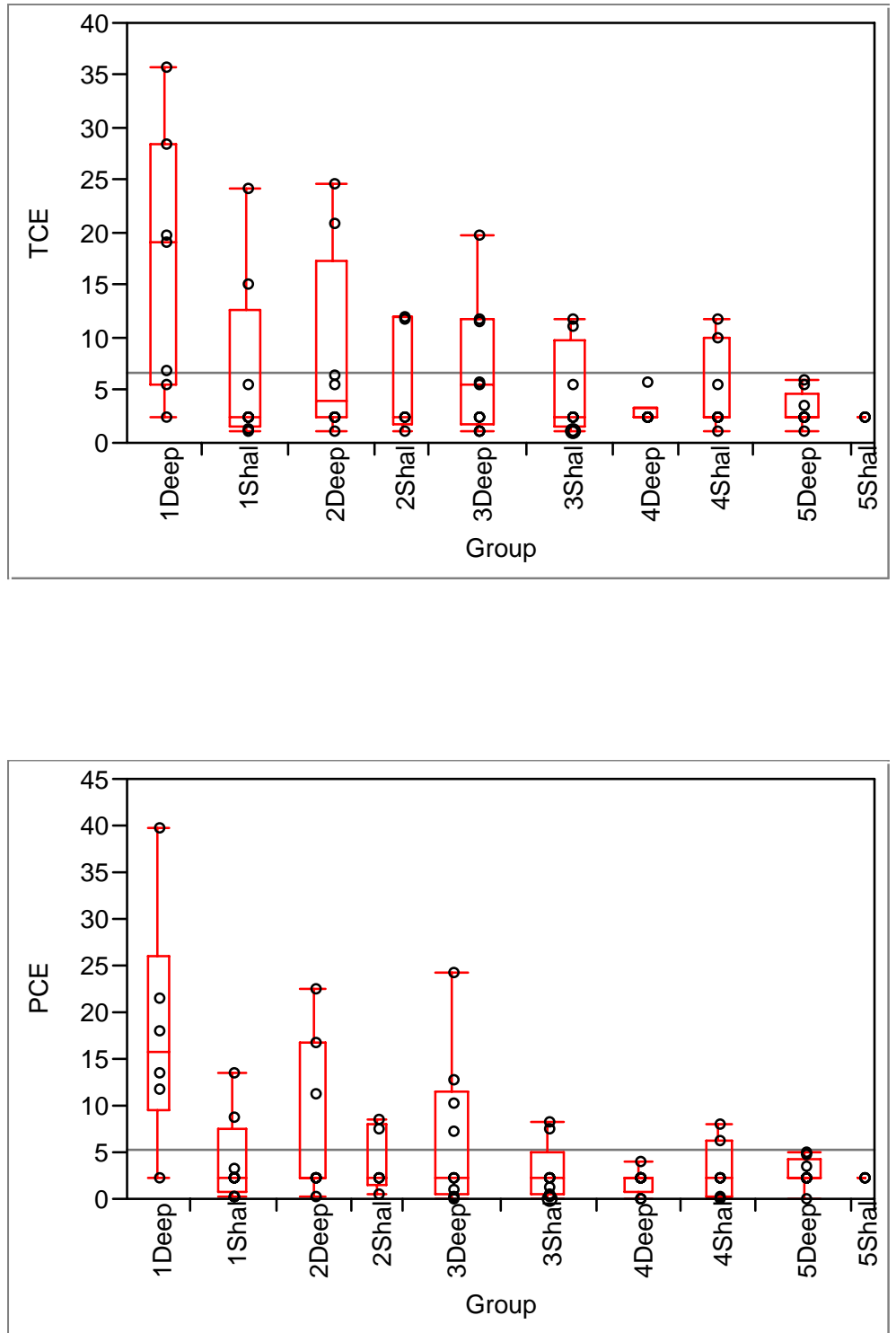

Figure 12. Phytoreactor Plots of Both TCE and PCE Concentration ( $\mu$ g/kg) Measurements in Soil Samples from Phytoreactors 1 through 5 and Two Sampling Depths (Shal=shallow \& Deep) 
more than one order of magnitude. Figure 12 suggests that both TCE and PCE concentrations have larger measurements in Phytoreactors 1 and 2 than other phytoreactors and are higher in the deep soil samples than in the shallow soil samples. This would be expected as the deep soils are near the source area of the phytoreactor groundwater supply. Although this pattern is similar for TCE and PCE, the data do not warrant any more rigorous statistical analysis.

\subsubsection{Transrespiration Measurements}

Measurements taken in June from the plants (pine, poplar, and Vetiver) did not show transrespiration of any detectable TCE and PCE. Wetland species were not measured in June. These measurements were repeated in August 2001, including the wetland plant "arrow arum” (Peltandra virginica), with the same results. The arrow arum was the only wetland species large enough to be measured.

\subsubsection{Plant Tissue Analysis}

Plant tissues (roots, stems, and leaves) and rhizosphere soil samples from the pine, poplar, Vetiver, and wetland plants have recently been taken from the phytoreactors for analysis of PCE, TCE and breakdown products including VC and c-DCE (Figure 13 and Table 1). VOCs were found in the tissues of all trees tested. Of interest are the pine trees that had the highest concentration of c-DCE with decreasing amounts from the roots and stems to the needles (Table 1). The Vetiver had the highest concentration of TCE in the leaves (Table 1). While root mass was not quantified, the Vetiver and poplars were observed to have greater root mass than the pines. This ongoing analysis will provide useful information on the fate of the chlorinated ethenes in the plants. No PCE or TCE metabolites (DCA, TCA, etc.) were found in the plant tissues tested.

As with the soil sample data, a typical data analysis by comparing concentration means is not reliable for any of the four constituents measured among plant types or plant parts. This is because the percentage of measurements at or below the detection limit was 91\%, 
FY 01 Phytoremediation of Chlorinated Ethenes in

WSRC-TR-2001-00437

Southern Sector Sediments of Savannah River Site

Revision 0

Savannah River Site

Page 40 of 62

November 2001
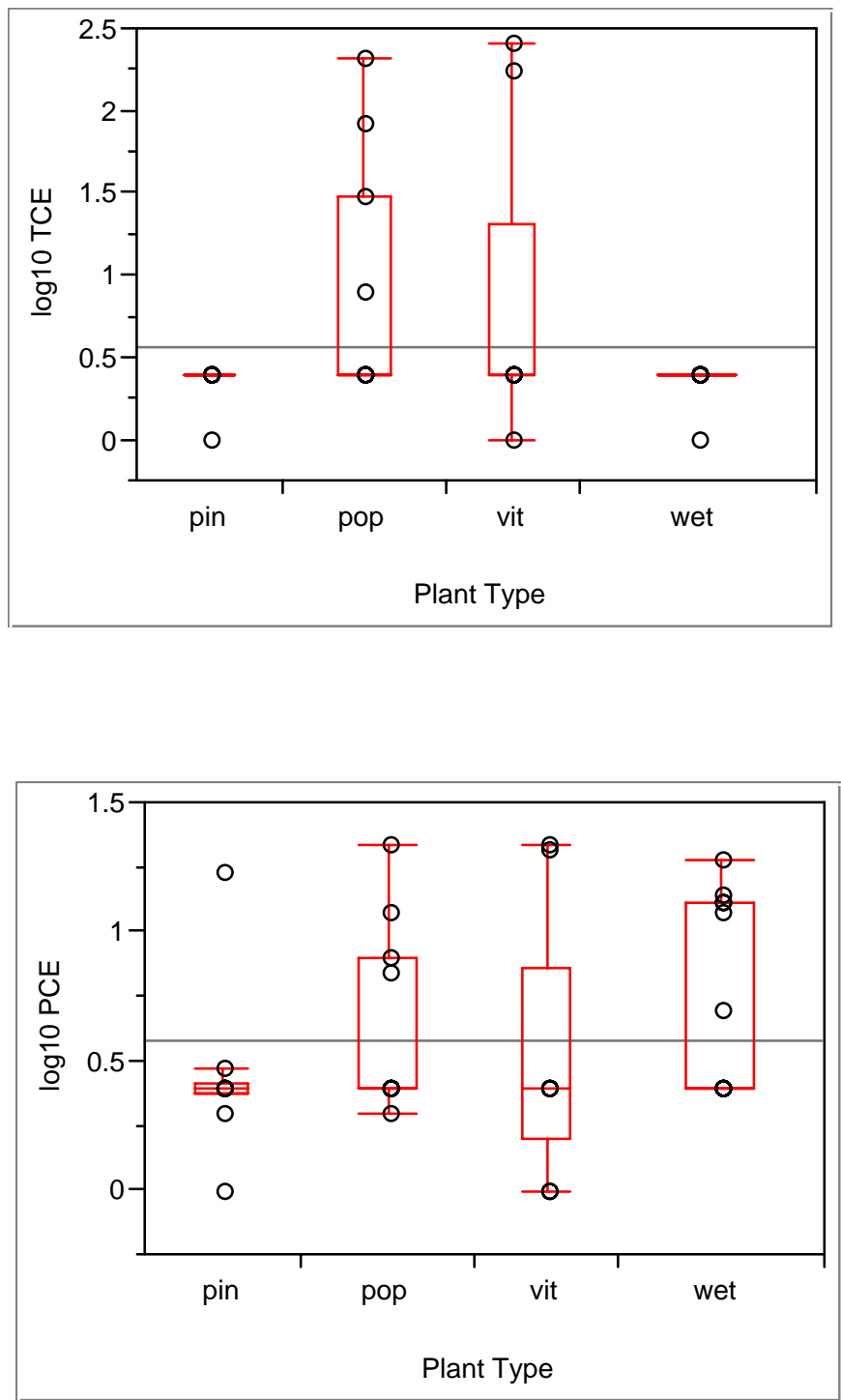

Figure 13. Phytoreactor Plots of Both TCE and PCE Concentration ( $\mu$ g/kg) Measurements Taken from Four Different Types or Plant Communities Across all Categories of plant Tissues. Measurements are reported as the Common Logarithms 
FY 01 Phytoremediation of Chlorinated Ethenes in

WSRC-TR-2001-00437

Southern Sector Sediments of Savannah River Site

Revision 0

Savannah River Site

Page 41 of 62

November 2001

Table 1. Plant Tissue Chlorinated Ethene Concentrations Summary

(Data is in Appendix 2)

\begin{tabular}{|c|c|c|c|c|}
\hline PLANT SAMPLE & VC & C-DCE & TCE & PCE \\
\hline & $\mu g / \mathrm{kg}$ & $\mu g / \mathrm{kg}$ & $\mu \mathrm{g} / \mathrm{kg}$ & $\mu \mathrm{g} / \mathrm{kg}$ \\
\hline Pine needles & 12 & 48 & ND & 9 \\
\hline Pine stem & ND & 877 & ND & ND \\
\hline Pine roots & $\mathrm{ND}$ & 1165 & ND & ND \\
\hline Pine soil & $\mathrm{ND}$ & $\mathrm{ND}$ & ND & $\mathrm{ND}$ \\
\hline Poplar leave & ND & ND & 146 & 11 \\
\hline Poplar stem & ND & ND & 20 & 5 \\
\hline Poplar root & 8 & ND & ND & 6 \\
\hline Poplar soil & ND & ND & ND & ND \\
\hline Poplar core & $\mathrm{ND}$ & ND & ND & 8 \\
\hline Vetiver leave & $\mathrm{ND}$ & ND & 219 & 11 \\
\hline Vetiver base & 14 & ND & ND & 11 \\
\hline Vetiver soil & ND & ND & ND & ND \\
\hline Wetland Leaf & ND & ND & ND & 13 \\
\hline Wetland Leaf Bs & ND & ND & ND & 12 \\
\hline Wetland Leaf R & $\mathrm{ND}$ & ND & ND & ND \\
\hline Wetland Leaf Pn & ND & ND & ND & 7 \\
\hline Wetland Pn Bs & ND & ND & ND & 10 \\
\hline Wetland Pn R & $\mathrm{ND}$ & 18 & $\mathrm{ND}$ & 17 \\
\hline Wetland soils & ND & ND & ND & ND \\
\hline
\end{tabular}

ND* stands for “Not detected". 
80\%, 80\%, and 72\% for VC, c-DCE, TCE, and PCE, respectively. Figure 13 identifies preliminary patterns in these data. Figure 14 presents the measurement results for TCE and PCE only. Because the measurements cross several orders of magnitude, the common logarithms of the concentrations are presented. This useful and widely accepted data scale transformation will stabilize the variability portrayed in the data plot from one data grouping to another. Note the suggestion here is that poplar and Vetiver may take up more TCE than the other two species. Compared to TCE, it also appears that only 10\% of the PCE, in the extreme, are taken up by the poplar, Vetiver, and wetland plants. Figure 14 presents the same data by plant tissue type or plant part. This plot suggests that the greatest accumulation of TCE is in the leaf and stem tissue. PCE, on the other hand, is not distinguished by accumulation in any plant part and does not show the extreme values that TCE shows.

\subsubsection{Microcosm Studies}

Microbial activity in the wetland and seepline soils has been investigated and was previously described. Anaerobic microcosms are being employed to assess both natural and amended activity for transformation of TCE and PCE to degradation products.

Samples were obtained from the seepline and wetland sediments at the site in July 2001. Soil samples were kept under refrigeration at $4{ }^{\circ} \mathrm{C}$ prior to microcosm preparation and then handled in an anaerobic glove box at all times. Soil samples were labeled in the following way.

\begin{tabular}{|l|l|l|}
\hline \multicolumn{1}{|c|}{ Label } & \multicolumn{1}{|c|}{ Description } & \multicolumn{1}{c|}{ Source } \\
\hline Wetland & $\begin{array}{l}\text { Mixture of 3 samples of soil from } \\
\text { Wetland sediments }\end{array}$ & $\begin{array}{l}\text { Seepline area at UTRC and } \\
\text { at same location of site for } \\
\text { soil in the Phytoreactor 5 }\end{array}$ \\
\hline Rhizosphere & Rhizosphere soil & $\begin{array}{l}\text { Mixed soils taken as soil } \\
\text { cores (2 cores /reactor) from } \\
\text { Phytoreactors 1, 2, 3, and 4 }\end{array}$ \\
\hline
\end{tabular}


FY 01 Phytoremediation of Chlorinated Ethenes in

WSRC-TR-2001-00437

Southern Sector Sediments of Savannah River Site

Revision 0

Savannah River Site

Page 43 of 62

November 2001
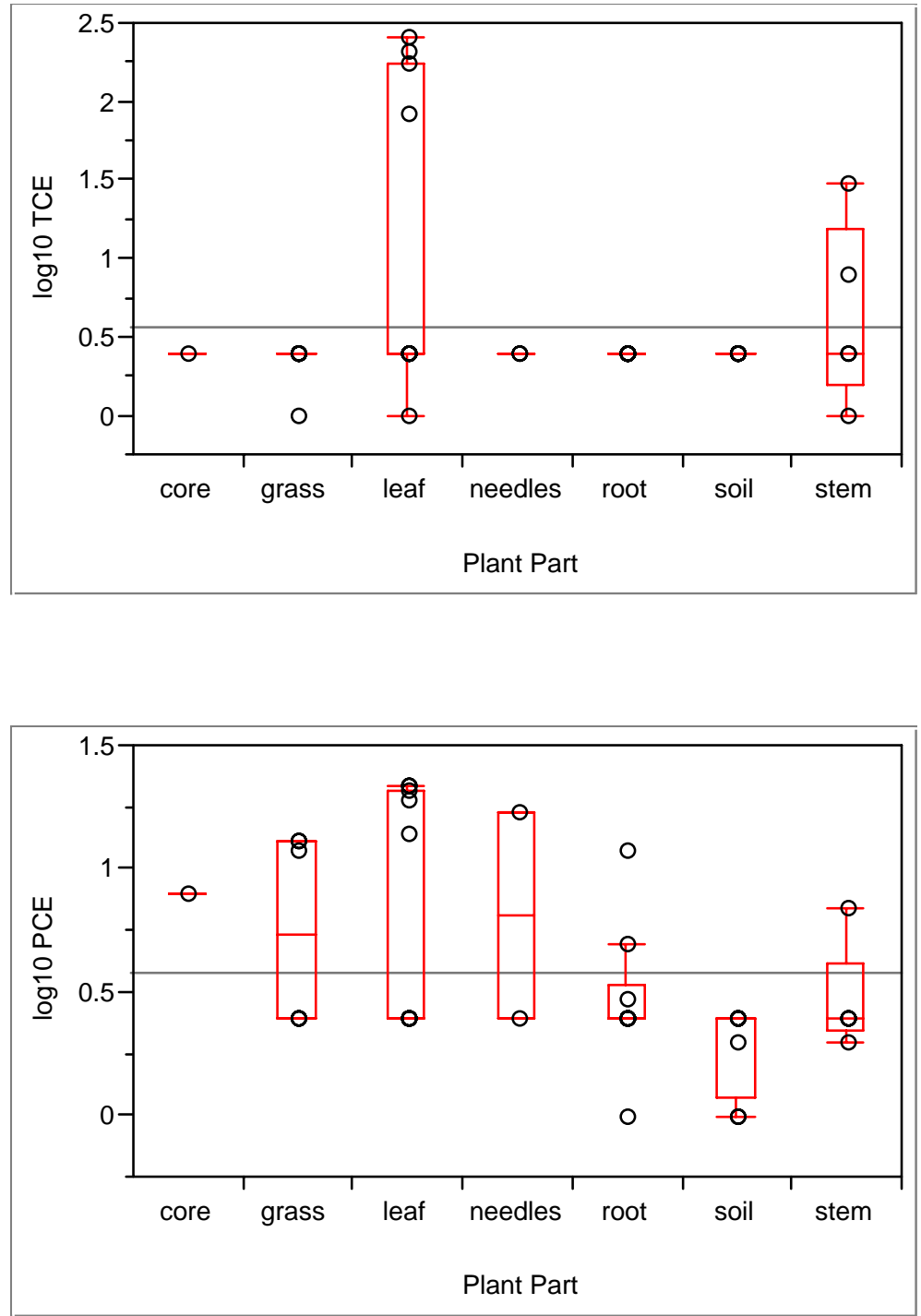

Figure 14. Plots of Both TCE and PCE Concentration Measurements $(\mu \mathrm{g} / \mathrm{kg})$ Taken from Seven Different Categories of Plant Tissues Across all Plant Types. Measurements Are Reported as the Common Logarithms 
After 6 weeks, all TCE- and PCE-containing microcosms established with rhizosphere and wetland sediments were analyzed. In the wetland microcosms it was evident that TCE was removed with no breakdown products (Figure 15). These data indicate that there are potential resident microbial populations transforming TCE in the wetland soils. This response is compatible with the porewater and effluent groundwater data, indicating in general an anaerobic environment within the saturated soil zone. The amendments seemed to enhance the biodegradation of TCE as compared to the unamended microcosm. The Osmocote ${ }^{\circledR}$ alone appeared to work the best (Figure 15). The oil could have influenced bioavailablity of the TCE. The killed control indicated little sorption relative to the TCE losses. Most of the sorption occurred in the first 24 hours after TCE addition, at which time the 0-day sample was taken. For the soils from the wetland, no dechlorination products (i.e., c-DCE) were found.

Unlike the wetland microcosms, the seepline soils used in the phytoreactors showed TCE degradation with production of c-DCE (Figures 16 through 20). The Osmocote ${ }^{\circledR}$ amendment (Figure 16) seemed to work better than the vegetable oil (Figure 17) or the vegetable oil combined with Osmocote ${ }^{\circledR}$ as less daughter product (c-DCE) was produced (Figure 18). With no amendment, it appeared all the TCE went to c-DCE (Figure 19). The killed control showed little TCE loss, indicating limited sorption and diffusional losses (Figure 20). It appears there are different populations of bacteria present in the two soils. This would explain the different results thus far. It is also possible that the rates of biodegradation are faster in the wetland soils since there is greater organic matter. The microcosm experiment will continue with samples taken to monitor VOC losses and ethene production through FY02. In addition, further work in microbial characterization will help probe these differences. 
FY 01 Phytoremediation of Chlorinated Ethenes in

WSRC-TR-2001-00437

Southern Sector Sediments of Savannah River Site

Revision 0

Savannah River Site

Page 45 of 62

November 2001

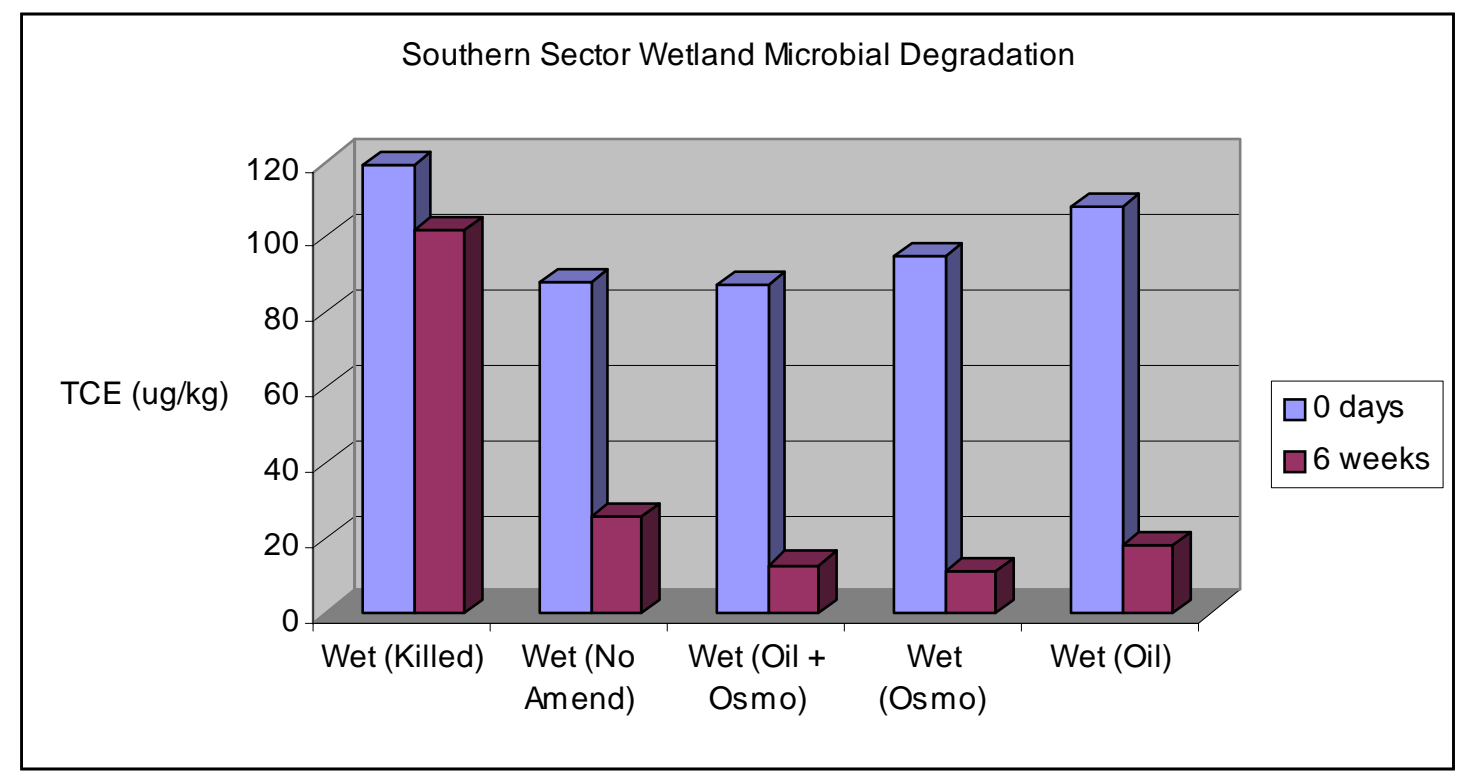

Figure 15. Microbial Degradation of TCE in Southern Sector Wetland Sediments

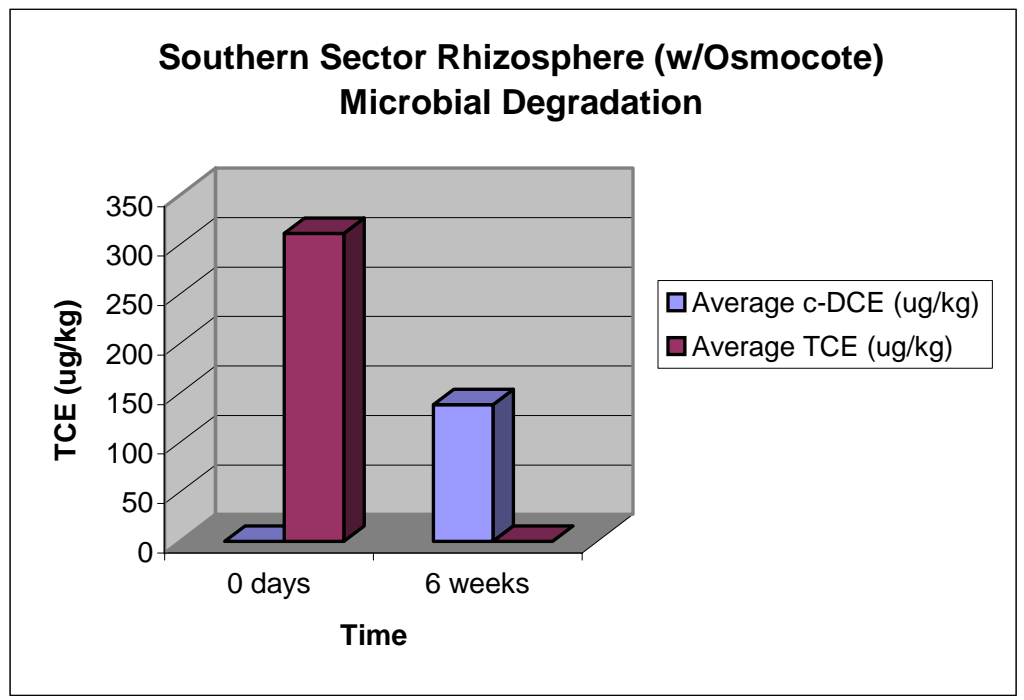

Figure 16. Microbial Degradation of TCE in Southern Sector Rhizosphere Sediments Amended with Osmocote ${ }^{\circledR}$ 
FY 01 Phytoremediation of Chlorinated Ethenes in

WSRC-TR-2001-00437

Southern Sector Sediments of Savannah River Site

Revision 0

Savannah River Site

Page 46 of 62

November 2001

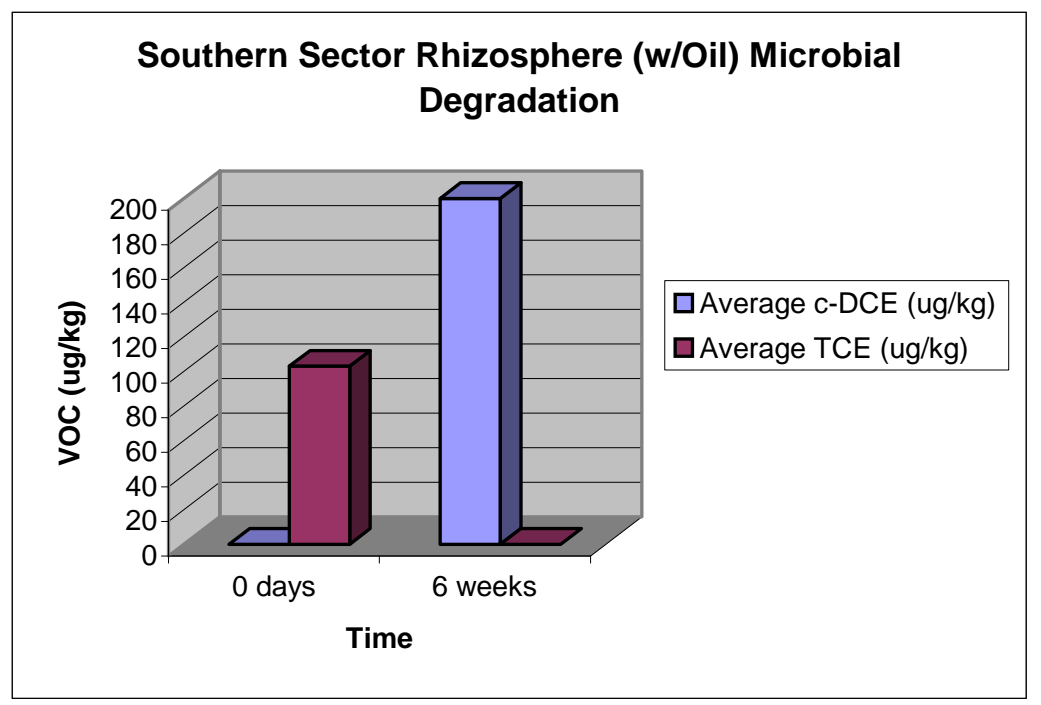

Figure 17. Microbial Degradation of TCE in Southern Sector Rhizosphere Sediments Amended with Soybean Oil

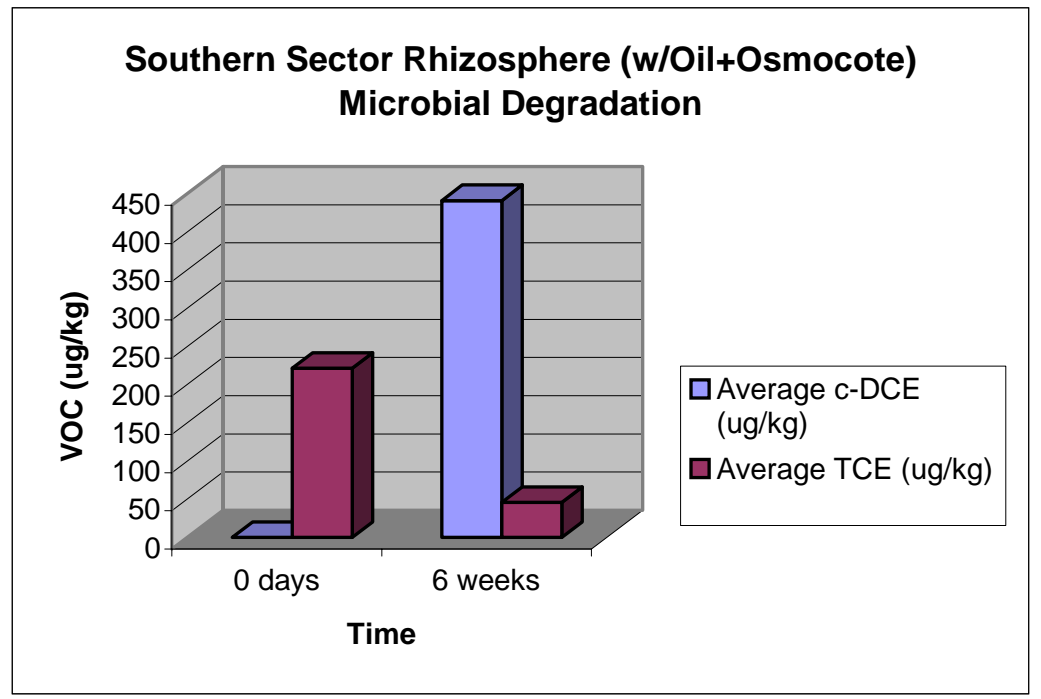

Figure 18. Microbial Degradation of TCE in Southern Sector Rhizosphere Sediments Amended with Osmocote ${ }^{\circledR}+$ Soybean Oil 
FY 01 Phytoremediation of Chlorinated Ethenes in

WSRC-TR-2001-00437

Southern Sector Sediments of Savannah River Site

Revision 0

Savannah River Site

Page 47 of 62

November 2001

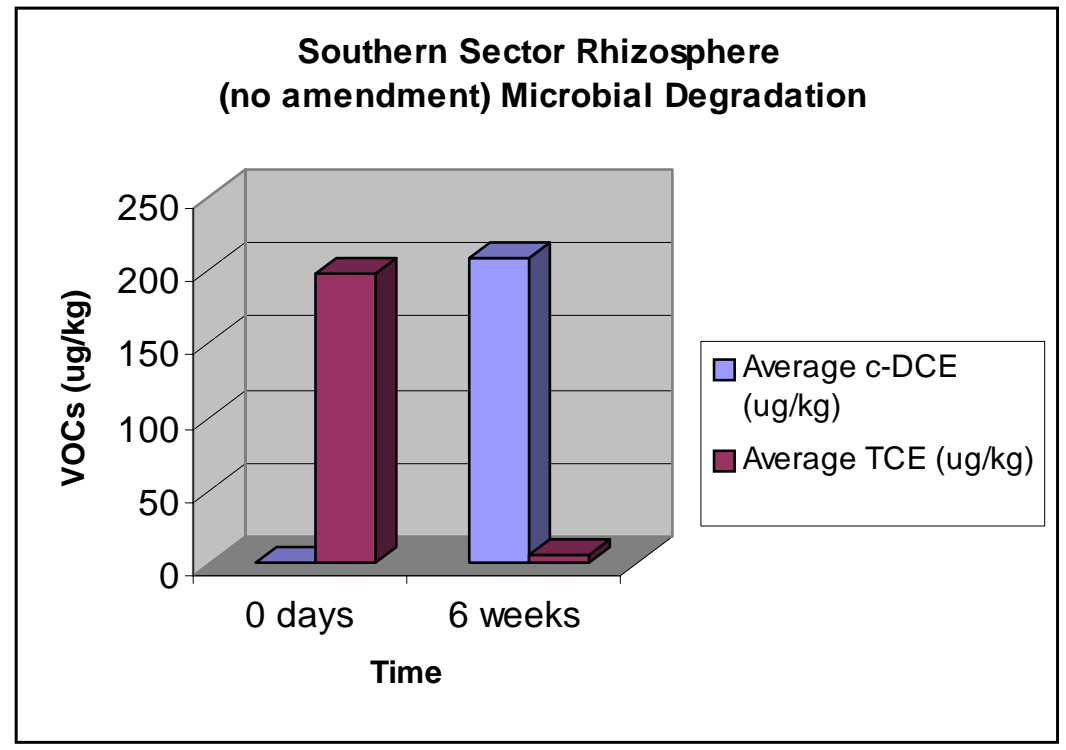

Figure 19. Microbial Degradation of TCE in Southern Sector Rhizosphere Sediments with No Amendments

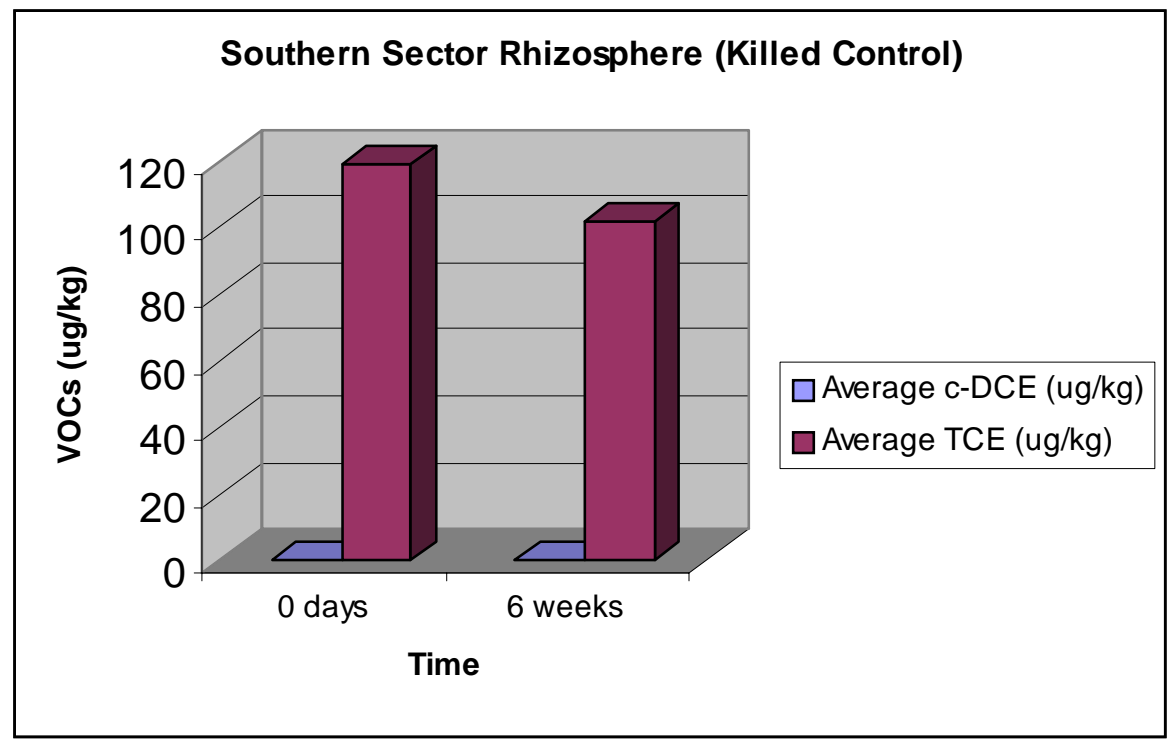

Figure 20. Microbial Degradation of TCE in Southern Sector Rhizosphere Sediments in Killed Control 


\subsubsection{Soil-Gases}

Table 2 shows the soil-gas production rates. The soil-moisture values concur with the daily values taken from Phytoreactor 4 by the weather station. There was no PCE or TCE detected in the soil-gases. Gas samples taken with Tedlar gasbags for GC analysis showed similar results. It is of interest that the $\mathrm{CO}_{2}$ production in Phytoreactor 1 with the pine trees was higher than the other phytoreactors. The shallow soil in Phytoreactor 1 demonstrated a ten-fold greater density of bacteria compared to that of other systems (Figure 21). Phytoreactor 1 also demonstrated some c-DCE production as indicated by the c-DCE in the pine tree tissues. The fact that c-DCE is a byproduct of anaerobic dechlorination of TCE and/or PCE and no c-DCE was ever detected in influent groundwater indicates a high level of microbial activity including methanogenic conditions at the bottom of the phytoreactor. The pine trees do not have extensive roots so this could allow the anaerobic conditions to prevail.

\subsubsection{Ion Chromatography}

Tables 3a and 3b show the influent and effluent groundwater chloride, nitrite, nitrate, phosphate, and sulfate cation concentrations. The composite water flows, and resulting flow of soluble ions, for the phytoreactors include influent groundwater, influent rainwater, subsurface discharge of groundwater and evaporative losses at the soil surface (Phytoreactors 1, 2, 3, and 4), and evapotranspiration by plants (in Phytoreactors 1, 2, 4, and 5). In addition, the soil placed in the phytoreactors contained pore water moisture with dissolved minerals as well as minerals sorbed to soil surfaces. These flows and sources need to be considered in the assessment of the ion data to date.

Chloride ion should be conservative in the phytoreactors and, except for an initial perturbation in March for the initial effluent, the influent and effluent data for chloride appear to be similar. 
FY 01 Phytoremediation of Chlorinated Ethenes in

WSRC-TR-2001-00437

Southern Sector Sediments of Savannah River Site

Revision 0

Savannah River Site

Page 49 of 62

November 2001

Table 2. Phytoreactor Soil-Gas Carbon Dioxide Production Rates, Moisture, PCE and TCE Concentrations

\begin{tabular}{|l|l|l|l|l|}
\hline Sample ID \# & $\mathrm{CO}_{2}(\mathrm{mg} / \mathrm{L})$ & Moisture $(\%)$ & TCE $(\mathrm{mg} / \mathrm{L})$ & PCE(mg/L) \\
\hline Box \#1 & 8300 & 22.4 & ND & ND \\
\hline Box \# 2 & 1185 & 21.4 & ND & ND \\
\hline Box \# 3 & 1433 & 20.3 & ND & ND \\
\hline Box \# 4 & 2088 & 20 & ND & ND \\
\hline Site Soil & 1026 & 22.4 & ND & ND \\
\hline
\end{tabular}

ND* stands for "Not detected". 
FY 01 Phytoremediation of Chlorinated Ethenes in

WSRC-TR-2001-00437

Southern Sector Sediments of Savannah River Site

Revision 0

Savannah River Site

Page 50 of 62

November 2001

\section{Soil CFU/gdrywt}

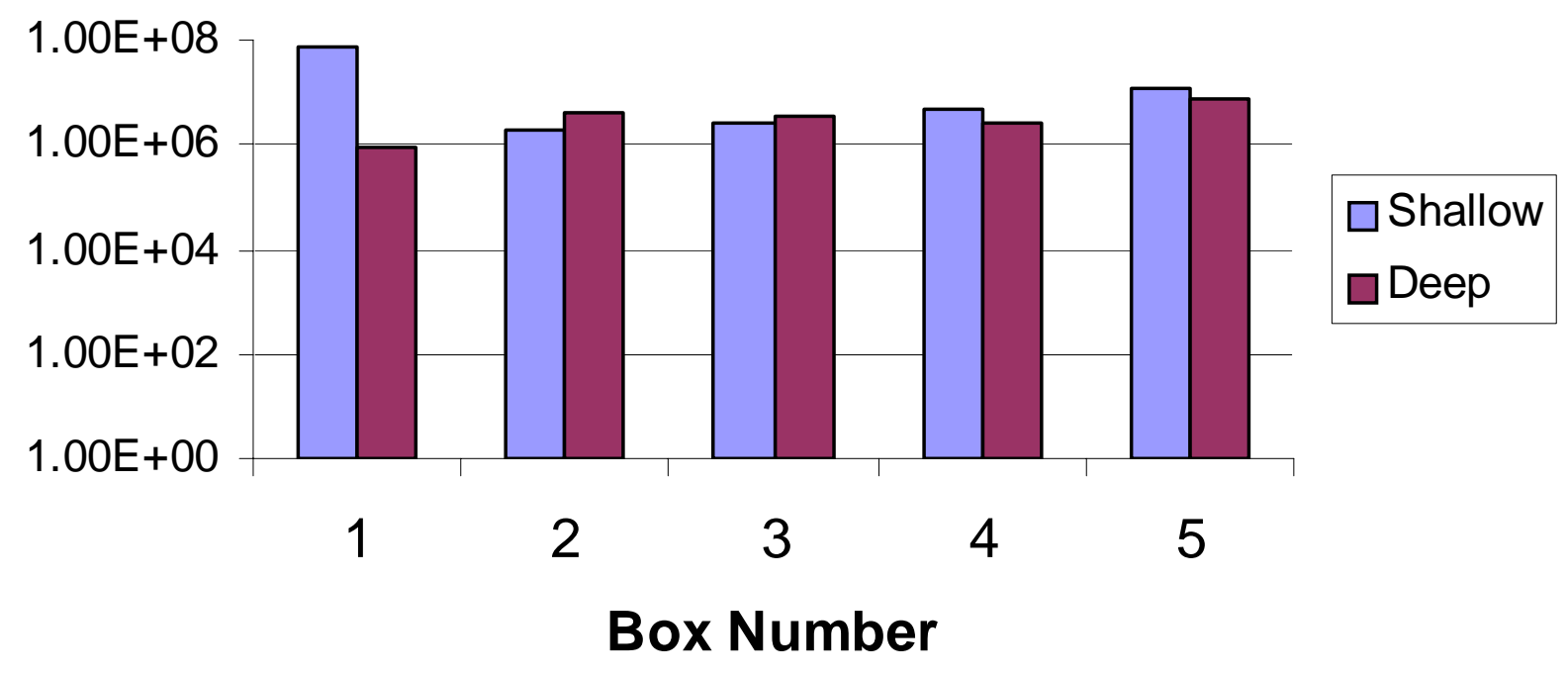

Figure 21. Total Colony-Forming Units (CFU) (bacteria/gram dry weight) for Shallow and Deep Phytoreactor Soils 
FY 01 Phytoremediation of Chlorinated Ethenes in

WSRC-TR-2001-00437

Southern Sector Sediments of Savannah River Site

Revision 0

Savannah River Site

Page 51 of 62

November 2001

Table 3a. Anion Results for Southern Sector Soil and Influent and Effluent Groundwater

\begin{tabular}{|c|c|c|c|c|c|}
\hline Sample ID \# & $\mathrm{Cl}^{-}(\mathrm{mg} / \mathrm{L})$ & $\mathrm{NO}_{2}^{-}(\mathrm{mg} / \mathrm{L})$ & $\begin{array}{c}\mathrm{NO}_{3}^{-} \\
(\mathrm{mg} / \mathrm{L}) \\
\end{array}$ & $\mathrm{SO}_{4}^{-}(\mathrm{mg} / \mathrm{L})$ & $\mathrm{PO}_{4}{ }^{-}(\mathrm{mg} / \mathrm{L})$ \\
\hline Box \# 1 In & 4.90 & $\mathrm{ND}$ & ND & 3.90 & 6.20 \\
\hline Box \# 1 Ef & 4.80 & ND & ND & 4.00 & 7.10 \\
\hline Box \# 2 In & 4.70 & ND & ND & 3.80 & 7.00 \\
\hline Box \# 2 Ef & 4.70 & $\mathrm{ND}$ & ND & 4.00 & 5.60 \\
\hline Box \# 3 In & 4.80 & ND & ND & 3.90 & 7.00 \\
\hline Box \# 3 Ef & 4.50 & $\mathrm{ND}$ & ND & 4.20 & 5.30 \\
\hline Box \# 4 In & 4.50 & ND & ND & 3.90 & 3.80 \\
\hline Box \# 4 Ef & 4.80 & 3.00 & ND & 3.80 & 6.70 \\
\hline Box \# 5 In & 4.80 & ND & $\mathrm{ND}$ & 3.90 & 7.00 \\
\hline Box \# 5 Ef & 4.20 & $\mathrm{ND}$ & $\mathrm{ND}$ & 2.70 & ND \\
\hline Box \# 1 Shallow & 8.90 & ND & $\mathrm{ND}$ & 8.20 & 9.80 \\
\hline Box \# 1 Deep & 9.20 & ND & ND & 7.30 & 9.30 \\
\hline Box \# 2 Shallow & 9.00 & ND & ND & 8.30 & 9.70 \\
\hline Box \# 2 Deep & 9.00 & ND & ND & 7.10 & 9.10 \\
\hline Box \# 3 Shallow & 8.80 & ND & $\mathrm{ND}$ & 7.50 & 9.50 \\
\hline Box \# 3 Deep & 9.00 & ND & $\mathrm{ND}$ & 7.40 & 9.50 \\
\hline Box \# 4 Shallow & 9.00 & $\mathrm{ND}$ & $\mathrm{ND}$ & 7.80 & 9.30 \\
\hline Box \# 4 Deep & 9.00 & $\mathrm{ND}$ & $\mathrm{ND}$ & 8.00 & 9.40 \\
\hline Box \# 5 Shallow & 9.30 & $\mathrm{ND}$ & ND & 7.50 & 9.20 \\
\hline Box \# 5 Deep & 9.10 & $\mathrm{ND}$ & $\mathrm{ND}$ & 7.60 & 9.40 \\
\hline
\end{tabular}

ND* stands for "Not Detected" 
FY 01 Phytoremediation of Chlorinated Ethenes in

WSRC-TR-2001-00437

Southern Sector Sediments of Savannah River Site

Revision 0

Savannah River Site

Page 52 of 62

November 2001

Table 3b. Cation Results for Southern Sector Soil and Influent and Effluent Groundwater

\begin{tabular}{|l|l|l|l|l|l|l|}
\hline \multicolumn{1}{|c|}{ Sample ID \# } & \multicolumn{1}{|c|}{$\mathbf{L i}^{+}$} & \multicolumn{1}{|c|}{$\mathbf{N a}^{+}$} & \multicolumn{1}{c|}{$\mathbf{N H}^{+}$} & \multicolumn{1}{|c|}{$\mathbf{M g}^{+{ }^{+}}$} & \multicolumn{1}{c|}{$\mathbf{C a}^{+}$} \\
\hline Box \#1 In & ND & 7.50 & ND & 1.40 & BDL & 1.50 \\
\hline Box \#1 Ef & ND & 8.40 & ND & 1.50 & BDL & 2.00 \\
\hline Box \#2 In & ND & 7.70 & ND & 1.20 & BDL & 1.50 \\
\hline Box \#2 Ef & ND & 10.70 & ND & 2.20 & BDL & 2.40 \\
\hline Box \#3 In & ND & 6.70 & ND & 1.30 & BDL & 1.70 \\
\hline Box \#3 Ef & ND & 6.70 & ND & 1.40 & BDL & 1.70 \\
\hline Box \# 4 In & ND & 8.50 & ND & 1.30 & BDL & 1.80 \\
\hline Box \# 4 Ef & BDL & 8.40 & ND & 1.30 & BDL & 1.60 \\
\hline Box \# 5 In & BDL & 7.10 & ND & 1.30 & BDL & 1.70 \\
\hline Box \# 5 Ef & ND & 8.00 & ND & 1.20 & BDL & 1.80 \\
\hline Box \# 1 Shallow & ND & 10.20 & ND & 1.60 & 2.10 & 2.10 \\
\hline Box \# 1 Deep & ND & 42.80 & ND & 1.20 & 1.90 & 1.10 \\
\hline Box \# 2 Shallow & ND & 36.10 & ND & 1.10 & 2.10 & BDL \\
\hline Box \# 2 Deep & ND & 24.50 & ND & 1.20 & 2.10 & BDL \\
\hline Box \# 3 Shallow & ND & 27.50 & ND & ND & 2.50 & BDL \\
\hline Box \# 3 Deep & ND & 31.90 & ND & 1.10 & 2.00 & BDL \\
\hline Box \# 4 Shallow & ND & 34.50 & ND & ND & 18.60 & 1.30 \\
\hline Box \# 4 Deep & ND & 44.10 & ND & ND & 18.70 & 1.30 \\
\hline Box \# 5 Deep & ND & 18.50 & ND & 1.70 & 2.10 & 3.20 \\
\hline
\end{tabular}

ND stands for "Not detected".

BDL means "Below Detection Limit". 
The initial phosphate concentration data in March may represent cross contamination of the influent tank but thereafter, influent and effluent phosphate concentrations were at trace levels.

Sulfate levels in the effluent of the phytoreactors appear to be elevated relative to the influent in all cases. Sulfate elution from the soils would appear to be the most plausible assessment of this increase, although it is possible that there is sulfide oxidation taking place in the saturated zone.

Nitrogen species in the system last year were nitrate and nitrite. Nitrate and nitrite appear at non-detect levels this year. The complete transformations of nitrate and nitrite are indicative of plant uptake of nitrogen species and denitrification by soil microbes. Plants will use nitrate as a primary source of nitrogen and this decrease is likely related to plant growth. Phytoreactor 3 has no trees, so the changes in this phytoreactor would be entirely microbially based. The occasional presence of nitrite in effluents would indicate that anaerobic respiration was in process and that nitrate conversion to nitrite and ultimately to nitrogen $\left(\mathrm{N}_{2}\right)$ was occurring in the phytoreactors. These nutrient responses need to be further examined in the coming year. Finally, the issue of nutrient addition is supported by these nitrogen and phosphorus data (i.e., phosphorus and nitrogen are at low levels and supplementation is warranted). No significant difference between treatments across time was found.

\subsubsection{Microbial Densities}

For all five phytoreactors the total microbial densities, as measured by AODC, were higher in the effluent groundwater than the influent groundwater for Phytoreactors 1 through 5 (Figure 22). The source of the influent bacteria is from influent groundwater, microbial growth in the influent tank, filter, and associated supply lines. Bacteria in the effluent water are from soils placed in the phytoreactors, influent groundwater, and environmental origin (air, rain, insects, etc.) because the phytoreactors are open systems. 
FY 01 Phytoremediation of Chlorinated Ethenes in

WSRC-TR-2001-00437

Southern Sector Sediments of Savannah River Site

Revision 0

Savannah River Site

Page 54 of 62

November 2001

\section{Total Cell Counts from Influent and Effluent Water for 2001}

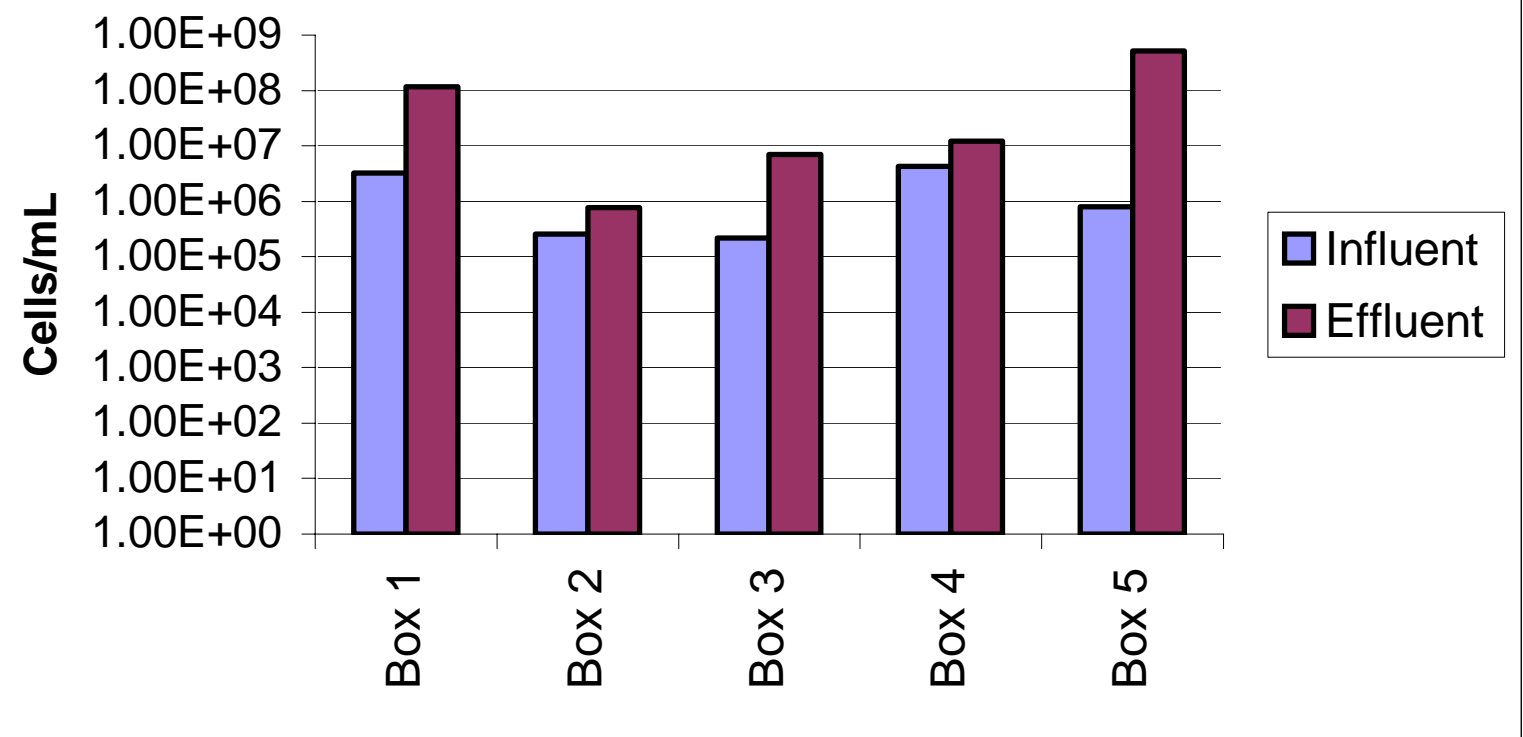

Figure 22. Total Microbial Densities (Bacteria/mL) for Influent and Effluent Phytoreactor Groundwater 
All phytoreactors were fertilized in the same manner in which nutrients are supplied to the soil microorganisms and the plants.

The viable microbial population densities of aerobic and facultative heterotrophic bacteria in groundwater as measured by colony-forming units/mL (CFUs/mL) showed increased viability in influent compared to effluent groundwater in Phytoreactors 1 through 4 (Figure 23). This is probably due to less viable cells being washed from rhizosphere soils that comprise the effluent biota. This would not be seen in the wetland soil, as is the case in Phytoreactor 5 (Figure 19).

The sediments were similarly tested for microbial densities. Those sediments taken from the shallow soils from the phytoreactors or top $10 \mathrm{~cm}$ had higher total microbial densities than the deeper or 100-cm sediments (Figure 24). More bacteria would be expected in the shallow soils because of increased oxygen and nutrient availability. As stated earlier, the fertilization regime can account for the similar high concentration of microbial densities in all phytoreactors (Figure 24). These data demonstrate the ubiquity and availability of indigenous soil microorganisms for biodegradation capacity under favorable conditions.

The total CFUs or viable bacteria were generally closer in densities for the sediments (Figure 21). The exception was Phytoreactor 1 where the shallow soils had densities around two orders of magnitude higher than the deeper soils (Figure 21). These data demonstrate the ubiquity and availability of indigenous soil microorganisms for biodegradation.

\subsection{Discussion}

While the phytoreactor groundwater supply tank was filled from well MSB 88C with consistent VOC concentrations (TCE 188 ppb, PCE 55 ppb), the phytoreactors actually 
FY 01 Phytoremediation of Chlorinated Ethenes in

WSRC-TR-2001-00437

Southern Sector Sediments of Savannah River Site

Revision 0

Savannah River Site

Page 56 of 62

November 2001

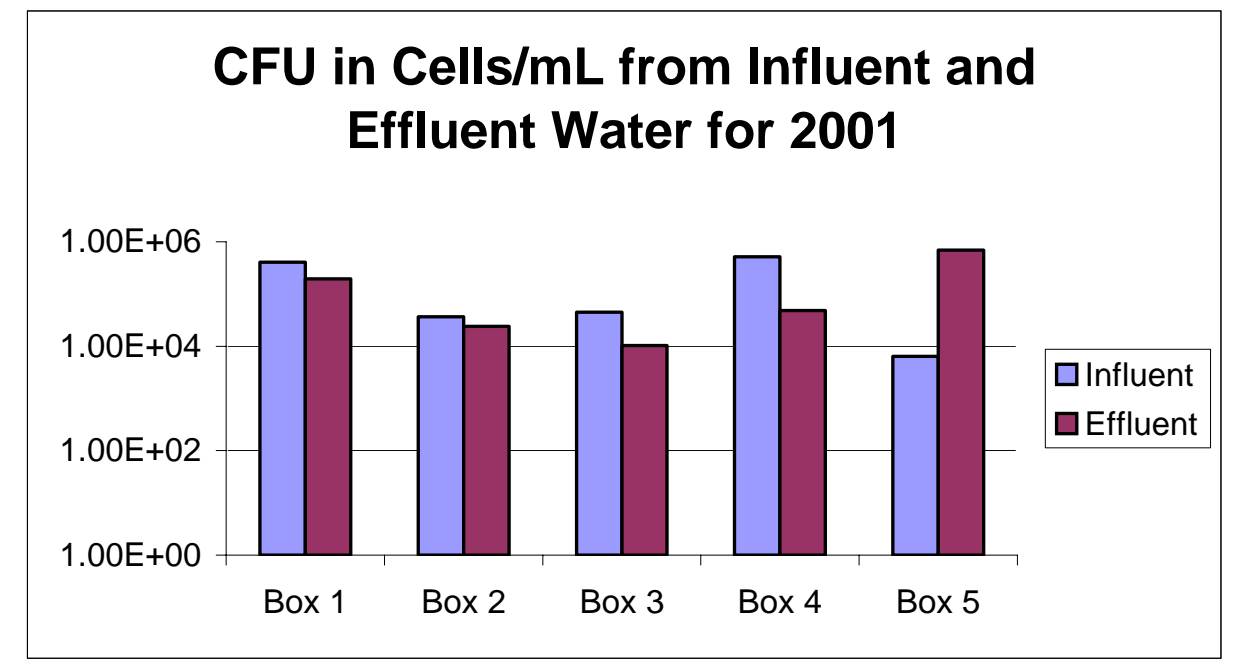

Figure 23. Total Colony-Forming Units (CFUs) in Phytoreactors Influent and Effluent groundwater Water for 2001

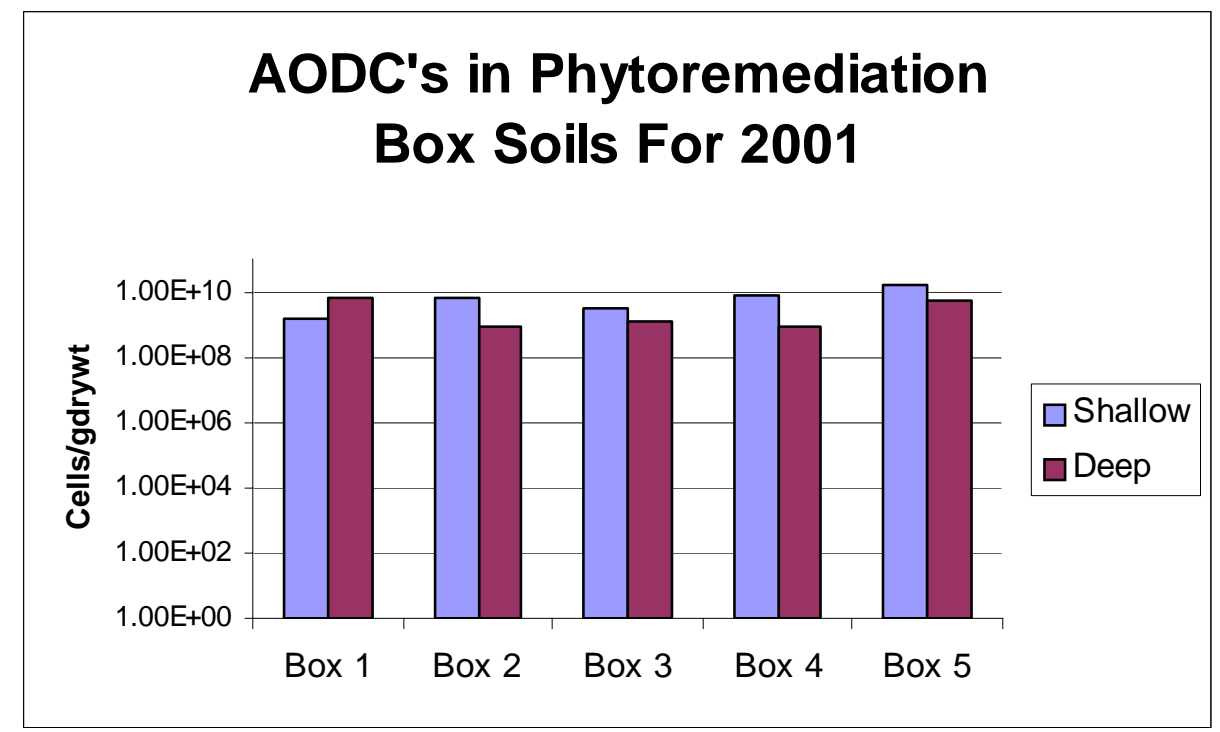

Figure 24. Total Microbial Densities (Bacteria/gram dry weight) for Shallow and Deep Phytoreactor Soils 
received groundwater through the supply system containing around $30 \mathrm{ppb}$ TCE and 10 ppb PCE (Figures 6 through 9). This is less than last year and may be attributable to the decrease in source well MSB-88C (Figure 5). These decreases may be due to weekly pumping of this well to fill the supply tank or the influence of the in situ air strippers located upgradient of MSB 88C. The groundwater VOC losses within the system itself are most likely due to volatilization as the system is now almost entirely stainless steel. While no statistically significant difference exists between phytoreactors when the influent and effluent groundwater PCE and TCE concentrations are compared, this evaluation did not take into consideration the overall water budget. As pointed out previously when the groundwater influent flow rates from the three phytoreactors are compared (Figure 9) to effluent flow rates (Figure 10), Phytoreactor 2 with the poplars appeared to have the highest influent groundwater input and yet the lowest effluent output measured. This is not surprising since the poplar grew on the average over five feet during the year while the pine grew just over one foot. In addition, the mass of roots from the poplar is much larger and extensive in the phytoreactors relative to the pine. The poplars required more maintenance as insects attacked the poplars during the summer of FY01. The pines had some problems with caterpillars but these were physically cleaned off. Groundwater flow through the phytoreactors was monitored but there were flow problems in Phytoreactors 1 and 5 (Figures 4a and 4e).

\subsection{CONCLUSION}

The findings of this treatability study indicate that both MNA and phytoremediation processes are important for TCE and PCE seepline groundwater remediation. Rhizosphere microbial activities tested here clearly demonstrate the degradation and transformation of TCE. The plants tested here, both indigenous (pine and wetland species) and introduced (hybrid poplar and Vetiver) species, demonstrated an uptake of chlorinated ethenes. Compared to the other species, the poplar and Vetiver took up more TCE while the pine had significant amounts of c-DCE in its tissues. The c-DCE was 
related to the plant tissue type. The order of c-DCE concentrations in the pine was root [c-DCE]>stem[c-DCE]>needle[c-DCE].

As measured by the microcosm studies, there is potential for complete chlorinated ethene remediation by MNA for the rhizosphere and wetland soils. The addition of low-cost amendments to sediment microcosms, including commercial fertilizer and vegetable oil, demonstrated accelerated TCE biodegradation rates. Recent groundwater characterization demonstrated diverse microbial populations including sulfate-reducers in seepline regions of chlorinated ethene contamination.

Phytoremediation and MNA are viewed to be "natural" or non-intrusive remediation technologies. Overall, they are safer and present potential lower costs. The Southern Sector seepline area is naturally vegetated and has a diverse range of habitats. Questions remain in terms of long-term predictability of these natural remediation technologies so far as "data gaps" concerning the complex seepline mixing zone environment. This treatability study is actively addressing some of these issues at the Southern Sector seepline. Additional information on the potential transrespiration rates and groundwater uptake by specific plants and MNA rates are needed to improve field-scale estimates of bioremediation potential.

This project is highly significant since most work in the phytoremediation area has been associated with significantly greater concentrations of VOCs (Burken and Schnoor 1998, Newman et al. 1999, and Doty et al. 2000). In FY01 the influent supply and effluent system underwent major changes including elevation of the height of the supply tank and an increase in the diameter of influent and effluent system piping to improve the groundwater flow rate continuity. The addition of a slow-release fertilizer was found to augment MNA as well as plant growth. Both MNA and phytoremediation have been demonstrated here. In FY01, the groundwater influent and output was monitored more stringently to better evaluate the contaminant removal. 
At SRS much of the VOCs in groundwater, with the exception of source areas, are in lower (ppb) concentrations, especially in the fringe areas of contaminant plumes (WSRC 2000b). The results of this project, with concurrent groundwater characterization studies, will enable better predictions of the VOC removal at the seepline. With the addition of the two new phytoreactors, the analysis of FY01 growing season seepline phyto- and bioactivity plus the FY02 growing season will be complete. Results to date indicate that phytoremediation and MNA have the potential to completely remove TCE and PCE in the Tims Branch flood plain and seepline.

\subsection{REFERENCES}

Anderson, T. A., E. A. Guthrie, and B. T. Walton, 1993. "Bioremediation in the Rhizosphere,” Environmental Science and Technology. 27:2630-2636

Anderson, T. A. and B. T. Walton, 1995. "Comparative Fate of ${ }^{14}$ C-Trichloroethylene in the Root Zone of Plants from a Former Solvent Disposal Site," Environ. Toxicol. Chem.,14:2041-2047

Balkwill, D. L., 1989. "Numbers, Diversity, and Morphological Characteristics of Aerobic Chemoheterotrophic Bacteria in Deep Subsurface Sediments from a Site in South Carolina,” Geomicrobiol., J. 7:33-52

Brigmon, R. L., N. C. Bell, D. L. Freedman, and C. B. Berry, 1998. "Natural Attenuation of Trichloroethylene in Rhizosphere Soils at the Savannah River Site,” J. Cont. Soils, $7: 433-453$

Brigmon, R.L., T.A. Anderson, and C.B. Fliermans, 1999. "Methanotrophic Bacteria in the Rhizosphere of Trichloroethylene Degrading Plants,” Int. J. Phytoremediation, 1:241253 
Burken, J.G., and J.L. Schnoor, 1998. "Predictive Relationships for Uptake of Organic Contaminants by Hybrid Poplar Trees,” Environmental Science and Technology, 32:3379-3385

Daniel, W. W, 1978. Applied Nonparametric Statistics, Houghton Mifflin Co. Boston, MA

Doty, S. L., T. Q. Shang, A. M. Wilson, J. Tangen, A. D. Westergreen, L. A. Newman, S. E. Strand, and M. P. Gordon, 2000. "Enhanced Metabolism of Halogenated Hydrocarbons in Transgenic Plants Containing Mammalian Cytochrome,” P450 2E1, Proc. Natl. Acad. Sci, 97:6287-6291

Fletcher, J. S. and R. S. Hedge, 1995. "Release of Phenols by Perennial Plant Roots and Their Potential Importance in Bioremediation,” Chemosphere, 31:3009-3016

Fliermans, C.B., Phelps, T.J., Ringelberg, D., Mikell, A.T., and White, D.C., 1988. “Mineralization of Trichloroethylene by Heterotrophic Enrichment Cultures,” Appl. Environ. Microbiol, 54:1709-1714

Hedge, R. S. and J. S. Fletcher, 1996. "Influence of Plant Growth Stage and Season on the Release of Root Phenolics by Mulberry as Related to Development of Phytoremediation Technology,” Chemosphere. 32:2471-2479

Nelson, M. J. K., S. O. Montgomery, and P. H. Pritchard, 1988. “Trichloroethylene Metabolism by Microorganisms that Degrade Aromatic Compounds,” Appl. Environ. Microbiol, 54:604-606

Newman, L.A., S.E. Strand, N. Choe, J. Duffy, G. Ekuan, M. Ruszaj, B.B. Shurtleff, J. Wilmoth, P. Heilman, and M. P. Gordon, 1997. "Uptake and Biotransformation of Trichloroethylene by Hybrid Poplars,” Environ. Sci. Technol, 31:1062-1067 
Newman, L.A., X. Wang, I.A. Muiznieks, G. Ekuan, M. Ruszaj, R. Cortellucci, D. Domroes, G. Karscig, T. Newman, R. S. Crampton, R. A. Hashmonay, M.G. Yost, P. E. Heilman, J. Duffy, M. P. Gordon and S.E. Strand, 1999. "Remediation of Trichloroethylene in an Artificial Aquifer with Trees: A Controlled Field Study,” Environ. Sci. Technol. 33:2257-2265

Nichols, T.D., D.C. Wolf, H.B. Rogers, C.A. Beyrouty, and C.M. Reynolds, 1997. "Rhizosphere Microbial Populations in Contaminated Soils," Water, Air, and Soil Poll. 95: $165-178$

Nietch, C.T., J.T. Morris, and D.A. Vroblesky, 1999. "Biophysical Mechanisms of Trichloroethylene Uptake and Loss in Bald Cypress Growing in Shallow Contaminated Groundwater,” Environ. Sci. Technol. 33:2899-2904

Orchard, B. J., W. J. Doucette, J.K. Chard, and B. Bugbee, 2000a. “A Novel Laboratory System for Determining Fate of Volatile Organic Compounds in Planted Systems,” Environ. Tox. \& Chem. 19:888-894

Orchard, B. J., W. J. Doucette, J.K. Chard, and B. Bugbee, 2000b. "Uptake of Trichloroethylene by Hybrid Poplar Trees Grown Hydroponically in Flow-Through Plant Growth Chambers,” Environ. Tox. \& Chem. 19:895-903

Quinn, J.J., M.C. Negri, R. R. Hinchman, L.P. Moos, J.B. Wozniak, E.G. Gatliff. 2001. "Predicting the Effect of Deep-Rooted Hybrid Poplars on the Groundwater Flow System at a Large-Scale Phytoremediation Site,” Int. J. Phytoremediation, 3:41-60

Schnabel, W.E., A.C. Dietz, J.G. Burken, J.L. Schnoor, and P.D. Alvarez, 1997. "Uptake and Transformation of Trichloroethylene by Edible Garden Plants,” Wat. Res. 4:816-824

Shann, J. R. 1995. “The Role of Plants and Plant/Microbial Systems in the Reduction of Exposure.” Environ. Health. Perspect. 103(Supplement 5):13-15 
Shimp, J. F., J. C. Tracy, L. C. Davis, E. Lee, W. Huang, L. E. Erickson, and J. L. Schnoor. 1993. "Beneficial Effects of Plants in the Remediation of Soil and Groundwater Contaminated with Organic Materials,” Crit. Rev. Environ. Sci. Technol. 23:41-77

Vroblesky, D.A., C.T. Nietch, and J.T. Morris, 1999. "Chlorinated Ethenes from Groundwater in Tree Trunks,” Environ. Sci. Technol. 33:510-515

Walton, B. T. and T. A. Anderson, 1990. "Microbial Degradation of Trichloroethylene in the Rhizosphere: Potential Application to Biological Remediation of Waste Sites,” Appl. Environ. Microbiol, 56:1012-1016

WSRC, 1996. Development of a Vertical Recirculation Well System for the A/M Area of the Savannah River Site. WSRC-RP-96-477, Revision 0, September 1996, Westinghouse Savannah River Company. Aiken, SC

WSRC, 1999. Characterization Report to Support Phytoremediation Efforts for the Southern Sector, Savannah River Site, Aiken, South Carolina. WSRC-TR-00113, Revision 0, April 1999, Westinghouse Savannah River Company. Aiken, SC

WSRC, 2000a. Phytoremediation of Trichloroethylene and Perchloroethylene in the Southern Sector of SRS: Interim Report, WSRC-TR-2000-00372, Revision 0, December 2000, Westinghouse Savannah River Company. Aiken, SC

WSRC, 2000b. Characterization Activities to Evaluate Chlorinated Solvent Discharges to Tims Branch from the A/M Area of the Savannah River Site, WSRC-TR-2000-00472, November 2000, Westinghouse Savannah River Company. Aiken, SC 
FY 01 Phytoremediation of Chlorinated Ethenes in

WSRC-TR-2001-00437

Southern Sector Sediments of Savannah River Site

Revision 0

Savannah River Site

Page A1-1 of A1-5

November 2001

APPENDIX 1. SOIL AND GROUNDWATER CHLORINATED ETHENE DATA

April 2001 Groundwater Chemistry Data

(Effluent Tank is the collection tank VOC concentration)

\begin{tabular}{|l|l|l|l|l|}
\hline \multicolumn{1}{|c|}{ Sample ID } & $\begin{array}{c}\text { Sample } \\
\text { Date }\end{array}$ & \multicolumn{1}{|c|}{$\begin{array}{c}\text { c-DCE } \\
(\mu \mathbf{g} / \mathbf{L})\end{array}$} & \multicolumn{1}{c|}{$\begin{array}{c}\text { TCE } \\
(\mu \mathbf{g} / \mathbf{L})\end{array}$} & \multicolumn{1}{c|}{$\begin{array}{c}\text { PCE } \\
(\mu \mathbf{g} / \mathbf{L})\end{array}$} \\
\hline Box \# 1 Influent & $4 / 1 / 01$ & 11.51 & 29.23 & 7.39 \\
\hline Box \# 1 Effluent & $4 / 1 / 01$ & 11.51 & 30.87 & 8.74 \\
\hline Box \# 2 Influent (A) & $4 / 1 / 01$ & 18.7 & 30.82 & 8 \\
\hline Box \# 2 Influent (B) & $4 / 1 / 01$ & 7.01 & BDL & 35.61 \\
\hline Box \# 2 Effluent & $4 / 1 / 01$ & BDL & BDL & 8.96 \\
\hline Box \# 3 Influent (A) & $4 / 1 / 01$ & BDL & 26.48 & 1.67 \\
\hline Box \# 3 Influent (B) & $4 / 1 / 01$ & 14.38 & 5.76 & 5 \\
\hline Box \# 3 Effluent & $4 / 1 / 01$ & 9.14 & BDL & 5.72 \\
\hline Box \# 4 Influent (A) & $4 / 1 / 01$ & BDL & 21.26 & BDL \\
\hline Box \# 4 Influent (B) & $4 / 1 / 01$ & 7.19 & 16.42 & 8.06 \\
\hline Box \# 4 Effluent (A) & $4 / 1 / 01$ & BDL & BDL & BDL \\
\hline Box \# 4 Effluent (B) & $4 / 1 / 01$ & BDL & 5.78 & BDL \\
\hline Box \# 5 Influent (A) & $4 / 1 / 01$ & 5.16 & 6.17 & BDL \\
\hline Box \# 5 Influent (B) & $4 / 1 / 01$ & 10.07 & 38.51 & 17.2 \\
\hline Box \# 5 Effluent (A) & $4 / 1 / 01$ & BDL & BDL & BDL \\
\hline Box \# 5 Effluent (B) & $4 / 1 / 01$ & BDL & 5.71 & 7.44 \\
\hline Effluent Tank (A) & $4 / 1 / 01$ & BDL & BDL & BDL \\
\hline Effluent Tank (B) & $4 / 1 / 01$ & BDL & BDL & BDL \\
\hline
\end{tabular}


FY 01 Phytoremediation of Chlorinated Ethenes in

WSRC-TR-2001-00437

Southern Sector Sediments of Savannah River Site

Revision 0

Savannah River Site

November 2001

Page A1-2 of A1-5

April 2001 Soil Chemistry Data

\begin{tabular}{|c|c|c|c|c|}
\hline Sample ID & Sample Date & $\begin{array}{l}\text { c-DCE } \\
(\mu \mathrm{g} / \mathrm{kg})\end{array}$ & $\begin{array}{l}\text { TCE } \\
(\mu \mathrm{g} / \mathrm{kg})\end{array}$ & $\begin{array}{l}\text { PCE } \\
(\mu g / k g)\end{array}$ \\
\hline Box \# 1 Shallow (A) & $4 / 1 / 01$ & BDL & BDL & BDL \\
\hline Box \# 1 Shallow (B) & $4 / 1 / 01$ & BDL & BDL & BDL \\
\hline Box \# 1 Shallow (C) & $4 / 1 / 01$ & BDL & BDL & BDL \\
\hline Box \# 1 Shallow (D) & $4 / 1 / 01$ & 8.63 & 5.66 & BDL \\
\hline Box \# 1 Deep (A) & $4 / 1 / 01$ & BDL & BDL & BDL \\
\hline Box \# 1 Deep (B) & $4 / 1 / 01$ & BDL & 5.66 & BDL \\
\hline Box \# 1 Deep (C) & $4 / 1 / 01$ & BDL & 6.96 & 13.65 \\
\hline Box \# 1 Deep (D) & $4 / 1 / 01$ & 17.26 & 28.59 & 11.86 \\
\hline Box \# 2 Shallow (A) & $4 / 1 / 01$ & BDL & BDL & BDL \\
\hline Box \# 2 Shallow (B) & $4 / 1 / 01$ & BDL & BDL & BDL \\
\hline Box \# 2 Shallow (C) & $4 / 1 / 01$ & BDL & BDL & BDL \\
\hline Box \# 2 Shallow (D) & $4 / 1 / 01$ & 10.07 & BDL & BDL \\
\hline Box \# 2 Deep (A) & $4 / 1 / 01$ & BDL & BDL & BDL \\
\hline Box \# 2 Deep (B) & $4 / 1 / 01$ & 7.53 & 6.49 & 11.33 \\
\hline Box \# 2 Deep (C) & $4 / 1 / 01$ & BDL & BDL & BDL \\
\hline Box \# 2 Deep (D) & $4 / 1 / 01$ & 8.63 & 5.68 & BDL \\
\hline Box \# 3 Shallow (A) & $4 / 1 / 01$ & BDL & BDL & BDL \\
\hline Box \# 3 Shallow (B) & $4 / 1 / 01$ & BDL & 5.71 & BDL \\
\hline Box \# 3 Shallow (C) & $4 / 1 / 01$ & BDL & BDL & BDL \\
\hline Box \# 3 Shallow (D) & $4 / 1 / 01$ & 10.07 & BDL & BDL \\
\hline Box \# 3 Deep (A) & $4 / 1 / 01$ & 5.44 & BDL & BDL \\
\hline Box \# 3 Deep (B) & $4 / 1 / 01$ & 5.75 & 5.98 & 10.28 \\
\hline Box \# 3 Deep (C) & $4 / 1 / 01$ & BDL & BDL & BDL \\
\hline Box \# 3 Deep (D) & $4 / 1 / 01$ & 8.06 & 5.68 & BDL \\
\hline Box \# 4 Shallow (A) & $4 / 1 / 01$ & BDL & BDL & BDL \\
\hline Box \# 4 Shallow (B) & $4 / 1 / 01$ & 8.63 & 5.68 & BDL \\
\hline Box \# 4 Shallow (C) & $4 / 1 / 01$ & BDL & BDL & BDL \\
\hline Box \# 4 Shallow (D) & $4 / 1 / 01$ & 5.75 & BDL & BDL \\
\hline Box \# 4 Deep (A) & $4 / 1 / 01$ & BDL & BDL & BDL \\
\hline Box \# 4 Deep (B) & $4 / 1 / 01$ & 5.75 & 5.98 & BDL \\
\hline Box \# 4 Deep (C) & $4 / 1 / 01$ & BDL & BDL & BDL \\
\hline Box \# 4 Deep (D) & $4 / 1 / 01$ & 7.19 & BDL & BDL \\
\hline Box \# 5 Deep (A) & $4 / 1 / 01$ & BDL & BDL & 5 \\
\hline Box \# 5 Deep (B) & $4 / 1 / 01$ & 10.07 & 5.71 & BDL \\
\hline Box \# 5 Deep (C) & $4 / 1 / 01$ & BDL & BDL & 5.16 \\
\hline Box \# 5 Deep (D) & $4 / 1 / 01$ & BDL & 6.17 & BDL \\
\hline
\end{tabular}


FY 01 Phytoremediation of Chlorinated Ethenes in

WSRC-TR-2001-00437

Southern Sector Sediments of Savannah River Site

Revision 0

Savannah River Site

Page A1-3 of A1-5

November 2001

May 2001 Groundwater Chemistry Data

(Effluent Tank is the collection tank VOC concentration)

\begin{tabular}{|l|l|l|l|l|}
\hline \multicolumn{1}{|c|}{ Sample ID } & Sample Date & c-DCE $(\mu \mathrm{g} / \mathbf{L})$ & TCE $(\mu \mathrm{g} / \mathbf{L})$ & PCE $(\mu \mathrm{g} / \mathbf{L})$ \\
\hline Box \# 1 Influent & $5 / 23 / 01$ & BDL & 31 & 24 \\
\hline Box \# 1 Effluent & $5 / 23 / 01$ & BDL & 24 & 15 \\
\hline Box \# 2 Influent & $5 / 23 / 01$ & BDL & 56 & 45 \\
\hline Box \# 2 Effluent & $5 / 23 / 01$ & BDL & 17 & 12 \\
\hline Box \# 3 Influent & $5 / 23 / 01$ & BDL & 49 & 36 \\
\hline Box \# 3 Effluent & $5 / 23 / 01$ & BDL & 29 & 21 \\
\hline Box \# 4 Influent & $5 / 23 / 01$ & BDL & 24 & 17 \\
\hline Box \# 4 Effluent & $5 / 23 / 01$ & BDL & 14 & 9 \\
\hline Box \# 5 Influent & $5 / 23 / 01$ & BDL & 41 & 30 \\
\hline Box \# 5 Effluent & $5 / 23 / 01$ & BDL & 9 & 5 \\
\hline Effluent Tank & $5 / 23 / 01$ & BDL & 9 & 6 \\
\hline
\end{tabular}

May, 2001 Soil Chemistry Data

\begin{tabular}{|l|l|l|l|l|}
\hline \multicolumn{1}{|c|}{ Sample ID } & Sample Date & c-DCE $(\mu \mathbf{g} / \mathbf{k g})$ & TCE $(\mu \mathbf{g} / \mathbf{k g})$ & PCE $(\mu \mathbf{g} / \mathbf{k g})$ \\
\hline Box 1 Shallow & $5 / 23 / 01$ & BDL & BDL & BDL \\
\hline Box 1 Deep & $5 / 23 / 01$ & BDL & 36 & 40 \\
\hline Box 2 Shallow & $5 / 23 / 01$ & BDL & BDL & BDL \\
\hline Box 2 Deep & $5 / 23 / 01$ & BDL & BDL & BDL \\
\hline Box 3 Shallow & $5 / 23 / 01$ & BDL & BDL & BDL \\
\hline Box 3 Deep & $5 / 23 / 01$ & BDL & BDL & BDL \\
\hline Box 4 Shallow & $5 / 23 / 01$ & BDL & BDL & BDL \\
\hline Box 4 Deep & $5 / 23 / 01$ & 41 & BDL & BDL \\
\hline Box 5 Deep & $5 / 23 / 01$ & BDL & BDL & BDL \\
\hline
\end{tabular}


FY 01 Phytoremediation of Chlorinated Ethenes in

WSRC-TR-2001-00437

Southern Sector Sediments of Savannah River Site

Revision 0

Savannah River Site

November 2001

Page A1-4 of A1-5

June 2001 Groundwater Chemistry Data

(Effluent Tank is the collection tank VOC concentration)

\begin{tabular}{|l|l|l|l|l|}
\hline \multicolumn{1}{|c|}{ Sample ID } & \multicolumn{1}{c|}{ Sample Date } & c-DCE $(\mu \mathbf{g} / \mathbf{L})$ & \multicolumn{1}{c|}{ TCE $(\mu \mathbf{g} / \mathbf{L})$} & PCE $(\mu \mathbf{g} / \mathbf{L})$ \\
\hline Box \# 1 Influent & $6 / 16 / 01$ & BDL & 17 & 8.6 \\
\hline Box \# 1 Effluent & $6 / 16 / 01$ & BDL & 11 & BDL \\
\hline Box \# 2 Influent & $6 / 16 / 01$ & BDL & 36 & 18 \\
\hline Box \# 2 Effluent & $6 / 16 / 01$ & BDL & 6.3 & BDL \\
\hline Box \# 3 Influent & $6 / 20 / 01$ & BDL & 30.4 & 14.4 \\
\hline Box \# 3 Effluent & $6 / 16 / 01$ & BDL & 14.9 & 7.4 \\
\hline Box \# 4 Influent & $6 / 20 / 01$ & BDL & 11.5 & 5.5 \\
\hline Box \# 4 Effluent & $6 / 20 / 01$ & BDL & BDL & BDL \\
\hline Box \# 5 Influent & $6 / 20 / 01$ & BDL & 24.4 & 11.4 \\
\hline Box \# 5 Effluent & $6 / 20 / 01$ & BDL & BDL & BDL \\
\hline Effluent Tank & $6 / 20 / 01$ & BDL & BDL & BDL \\
\hline
\end{tabular}

June 2001 Soil Chemistry Data

\begin{tabular}{|l|l|l|l|l|}
\hline \multicolumn{1}{|c|}{ Sample ID } & \multicolumn{1}{|c|}{ Sample Date } & \multicolumn{1}{|c|}{ c-DCE $(\mu \mathbf{g} / \mathbf{k g})$} & TCE $(\mu \mathbf{g} / \mathbf{k g})$ & PCE $(\mu \mathbf{g} / \mathbf{k g})$ \\
\hline SS Box \#1 Shallow A & $6 / 21 / 01$ & BDL & BDL & BDL \\
\hline SS Box \#1 Shallow B & $6 / 20 / 01$ & BDL & BDL & BDL \\
\hline SS Box \#1 Deep A & $6 / 20 / 01$ & BDL & BDL & BDL \\
\hline SS Box \#1 Deep B & $6 / 20 / 01$ & BDL & BDL & BDL \\
\hline SS Box \#2 Shallow A & $6 / 20 / 01$ & BDL & BDL & BDL \\
\hline SS Box \#2 Shallow B & $6 / 20 / 01$ & BDL & BDL & BDL \\
\hline SS Box \#2 Deep A & $6 / 20 / 01$ & BDL & BDL & BDL \\
\hline SS Box \#2 deep B & $6 / 20 / 01$ & BDL & BDL & BDL \\
\hline SS Box \#3 Shallow A & $6 / 20 / 01$ & BDL & BDL & BDL \\
\hline SS Box \#3 Shallow B & $6 / 20 / 01$ & BDL & BDL & BDL \\
\hline SS Box \#3 Deep A & $6 / 20 / 01$ & BDL & 20.0 & 13.0 \\
\hline SS Box \#3 Deep B & $6 / 20 / 01$ & BDL & BDL & BDL \\
\hline SS Box \#4 Shallow A & $6 / 20 / 01$ & BDL & BDL & BDL \\
\hline SS Box \#4 Shallow B & $6 / 20 / 01$ & BDL & BDL & BDL \\
\hline SS Box \#4 Deep A & $6 / 20 / 01$ & BDL & BDL & BDL \\
\hline SS Box \#4 Deep B & $6 / 20 / 01$ & BDL & BDL & BDL \\
\hline SS Box \#5 Shallow A & $6 / 20 / 01$ & BDL & BDL & BDL \\
\hline SS Box \#5 Shallow B & $6 / 20 / 01$ & BDL & BDL & BDL \\
\hline SS Box \#5 Deep A & $6 / 20 / 01$ & BDL & BDL & BDL \\
\hline SS Box \#5 Deep B & $6 / 20 / 01$ & BDL & \\
\hline
\end{tabular}


FY 01 Phytoremediation of Chlorinated Ethenes in

WSRC-TR-2001-00437

Southern Sector Sediments of Savannah River Site

Revision 0

Savannah River Site

November 2001

Page A1-5 of A1-5

July 2001 Groundwater Chemistry Data

(Tank SS is the supply tank VOC concentration and Effluent Tank is the collection tank VOC concentration)

\begin{tabular}{|l|l|l|l|l|}
\hline \multicolumn{1}{|c|}{ Sample ID } & \multicolumn{1}{|c|}{ Sample Date } & c-DCE $(\mu \mathbf{g} / \mathbf{k g})$ & TCE $(\mu \mathbf{g} / \mathbf{k g})$ & PCE $(\mu \mathbf{g} / \mathbf{k g})$ \\
\hline Tank SS A & $07 / 26 / 01$ & BDL & 15 & 15 \\
\hline Tank SS B & $07 / 26 / 01$ & BDL & 8.5 & 9.5 \\
\hline Box 1 Influent & $07 / 26 / 01$ & BDL & 17.0 & 13.0 \\
\hline Box 2 Influent & $07 / 26 / 01$ & BDL & 14 & 10.6 \\
\hline Box 3 Influent & $07 / 26 / 01$ & BDL & 15 & 10.9 \\
\hline Box 4 Influent & $07 / 26 / 01$ & BDL & 6.0 & 5.0 \\
\hline Box 5 Influent & $07 / 26 / 01$ & BDL & 18 & 12 \\
\hline Box 1 Effluent & $07 / 26 / 01$ & 5.00 & 6 & 7 \\
\hline Box 2 Effluent & $07 / 26 / 01$ & BDL & BDL & BDL \\
\hline Box 3 Effluent & $07 / 26 / 01$ & BDL & 6.2 & BDL \\
\hline Box 4 Effluent & $07 / 26 / 01$ & 14 & 5.7 & BDL \\
\hline Box 5 Effluent & $07 / 26 / 01$ & BDL & BDL & BDL \\
\hline Effluent Tank A & $07 / 26 / 01$ & BDL & BDL & BDL \\
\hline Effluent Tank B & $07 / 26 / 01$ & BDL & BDL & BDL \\
\hline
\end{tabular}


APPENDIX 2. PLANT CHEMICAL DATA

Sample Id

Misc Info

A Poplar core

A Poplar soil

A Poplar roots

A Poplar leaf

A Poplar stems

B Poplar Soil

B Poplar roots

B Poplar leaf

B Poplar stems

Wetland sediment

Wetland sediment

Wetland leaf base

Wetland leaf base

Wetland leaf base

Wetland grass leaf

Wetland leaf base

$B$ Vitiver leave

$B$ Vitiver soil

B Vitiver root

$B$ Vitiver leaf soil

$B$ Vitiver leaf base

A Vitiver leave

A Vitiver soil

a vitiver root

a vitiver leaf base

Wetland grass $B$

Wetland leaf base $B$

Wetland sediment $C$

A Wetland roots

Wetland leaf B

Wetland roots pn $B$

Wetland grass leaf base $B$

Wetland grass leaf $B$

Wetland grass roots $B$

A pine needles

A pine soil

A pine roots

A pine stem

$B$ pine needles

$B$ pine roots

$B$ pine soil

$B$ pine stem

$C$ pine roots

C pine stem

C poplar soil

C poplar roots
Sample

Date

7/26/01

$7 / 26 / 01$

$7 / 26 / 01$

$7 / 26 / 01$

$7 / 26 / 01$

$7 / 26 / 01$

$7 / 26 / 01$

$7 / 26 / 01$

$7 / 26 / 01$

$7 / 26 / 01$

$7 / 26 / 01$

$7 / 26 / 01$

$7 / 26 / 01$

$7 / 26 / 01$

$7 / 26 / 01$

7/26/01

$7 / 26 / 01$

$7 / 26 / 01$

$7 / 26 / 01$

$7 / 26 / 01$

$7 / 26 / 01$

$7 / 26 / 01$

$7 / 26 / 01$

$7 / 26 / 01$

$7 / 26 / 01$

$7 / 26 / 01$

$7 / 26 / 01$

$7 / 26 / 01$

$7 / 26 / 01$

$7 / 26 / 01$

$7 / 26 / 01$

$7 / 26 / 01$

$7 / 26 / 01$

$7 / 26 / 01$

$7 / 26 / 01$

$7 / 26 / 01$

$7 / 26 / 01$

$7 / 26 / 01$

$7 / 26 / 01$

$7 / 26 / 01$

$7 / 26 / 01$

$7 / 26 / 01$

$7 / 26 / 01$

$7 / 26 / 01$

$7 / 26 / 01$

$7 / 26 / 01$
Methlyene

vC 1,1 DCE Chloride t-DCE c-DCE TCE PCE

$\mathrm{ug} / \mathrm{kg} \mathrm{ug} / \mathrm{kg} \mathrm{ug} / \mathrm{kg} \quad \mathrm{ug} / \mathrm{kg} \mathrm{ug} / \mathrm{kg} \mathrm{ug} / \mathrm{kg} \mathrm{ug} / \mathrm{kg}$

$\begin{array}{lllllll}\text { ND } & 2 & \text { ND } & \text { ND } & \text { ND } & \text { ND } & 8\end{array}$

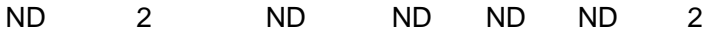

$\begin{array}{lllllll}\text { ND } & 22 & 99 & \text { ND } & \text { ND } & \text { ND } & 12\end{array}$

$\begin{array}{lllllll}\text { ND } & 130 & \text { ND } & \text { ND } & \text { ND } & 84 & 22\end{array}$

$\begin{array}{lllllll}\text { ND } & 14 & \text { ND } & \text { ND } & \text { ND } & 8 & 7\end{array}$

$\begin{array}{lllllll}4 & 20 & 1 & 0 & \text { ND } & \text { ND } & \text { ND }\end{array}$

$15 \quad 69$

$17 \quad 134$

ND 3

ND $\quad 1$

ND 3

ND 9

ND 14

ND $\quad 712$

ND $\quad 917$

ND 552

ND 24

ND 1

ND 1

ND 0

$27 \quad 131$

ND 24

ND 0

ND $\quad 99$

ND 44

ND 14

ND 93

ND ND

ND 366

ND 203

ND 19

ND 363

ND 1036

ND 103

$23 \quad 1386$

ND

ND

ND

ND

ND

ND

ND

ND

ND

ND

ND
ND

5

4

ND

ND

129

650

1078

614

248

ND

ND

4

26

ND

110

ND

ND

ND

ND

143

ND

146

698

ND

1183

4261

ND

574

9

98

ND

ND

ND

ND

ND

ND

ND

ND

ND
3 ND ND ND

$\begin{array}{cccc}\text { ND } & 4 & 208 & \text { ND }\end{array}$

ND ND 110

ND 10 ND 0

ND ND ND 19

ND ND ND 14

ND ND ND 12

4807 ND ND 13

3 ND ND 13

ND ND ND ND

$\begin{array}{llll}27 & 1 & \text { ND } & \text { ND }\end{array}$

1 ND ND ND

ND ND 1 ND

ND ND $263 \quad 22$

ND ND ND 1

2 ND ND 1

ND ND ND 21

0 ND ND ND

ND 1 ND ND

ND ND ND ND

ND 3 ND 5

ND ND ND ND

ND 18 ND ND

ND ND ND ND

ND ND ND ND

ND ND ND 0

ND ND ND 17

$\begin{array}{llll}1 & 1 & \text { ND } & 1\end{array}$

27031 ND ND

ND 359 ND ND

ND $96 \quad$ ND ND

ND 1763 ND 3

ND ND ND ND

$\begin{array}{llll}\text { ND } & 1309 & 1 & 2\end{array}$

ND 1701 ND ND

ND 444 ND ND

ND ND ND ND

ND ND ND ND
ND $3 \quad 175 \quad$ ND 